$$
\begin{gathered}
\text { UNIVERSIDADE DE SÃO PAULO } \\
\text { FFCLRP - DEPARTAMENTO DE PSICOLOGIA E EDUCAÇÃO } \\
\text { PROGRAMA DE PÓS-GRADUAÇÃO EM PSICOBIOLOGIA }
\end{gathered}
$$

\title{
Caricatura e reconhecimento de faces
}

\author{
Ana Irene Fonseca Mendes
}

Tese apresentada à Faculdade de Filosofia, Ciências e Letras de Ribeirão Preto da USP, como parte das exigências para a obtenção do título de Doutor em Ciências, Área: Psicobiologia.

RIBEIRÃO PRETO - SP 
UNIVERSIDADE DE SÃO PAULO

FFCLRP - DEPARTAMENTO DE PSICOLOGIA E EDUCAÇÃO

PROGRAMA DE PÓS-GRADUAÇÃO EM PSICOBIOLOGIA

\section{Caricatura e reconhecimento de faces}

Ana Irene Fonseca Mendes

Orientador: Prof. Dr. Sérgio Sheiji Fukusima

Tese apresentada à Faculdade de Filosofia, Ciências e Letras de Ribeirão Preto da USP, como parte das exigências para a obtenção do título de Doutor em Ciências, Área: Psicobiologia.

RIBEIRÃO PRETO - SP 
As ilustrações da capa são de autoria do ilustrador Eduardo Baptistão. As imagens foram utilizadas com a autorização do autor.

Mendes, Ana Irene Fonseca

Caricatura e reconhecimento de faces.

Ribeirão Preto, 2007.

$111 \mathrm{p} .: 30 \mathrm{~cm}$

Tese apresentada à Faculdade de Filosofia Ciências e Letras de Ribeirão Preto/USP - Departamento de Psicologia e Educação.

Área de Concentração: Psicobiologia.

Orientador: Prof. Dr. Sérgio Sheiji Fukusima

1. reconhecimento de faces. 2. protótipo facial. 3. caricatura. 


\section{FOLHA DE APROVAÇÃO}

Ana Irene Fonseca Mendes

Caricatura e o reconhecimento de faces

Tese apresentada à Faculdade de Filosofia, Ciências e Letras de Ribeirão Preto da USP, como parte das exigências para a obtenção do título de Doutor em Ciências, Área: Psicobiologia.

Aprovado em:

\section{BANCA EXAMINADORA}

Prof. Dr. Sérgio Sheiji Fukusima Instituição: FFCLRP-USP

Assinatura:

Prof. Dr. Sílvio Morato de Carvalho Instituição: FFCLRP-USP

Assinatura:

Prof ${ }^{a}$ Dra. Maria Lúcia de Bustamante Simas

Instituição: UFPE

Assinatura:

Prof ${ }^{a}$ Dra. Cristina Marta Del-Ben

Instituição: FMRP-USP

Assinatura:

Prof. Dr. Jesus Landeira Fernandez

Instituição: Estácio de Sá e PUC - RJ

Assinatura:

Prof. Dr.

Instituição:

Assinatura: 
"So she got up, and held out her hand. 'Good-bye, till we meet again!' she said as cheerfully as she could.

'I shouldn't know you again if we did meet,' Humpty Dumpty replied in a discontented tone, giving her one of his fingers to shake; 'you're so exactly like other people.'

'The face is what one goes by, generally, 'Alice remarked in a thoughtful tone.

'That's just what I complain of,' said Humpty Dumpty. 'Your face is the same as everybody has - the two eyes, so -' (marking their places in the air with this thumb) 'nose in the middle, mouth under. It's always the same. Now if you had the two eyes on the same side of the nose, for instance - or the mouth at the top - that would be some help.'

'It wouldn't look nice, ' Alice objected. But Humpty Dumpty only shut his eyes and said 'Wait till you've tried."'

(Lewis Carroll, Through The Looking Glass) 
À Sofia, que desenha faces como ninguém e a minha mãe, a maior guerreira que conheço. 


\section{Agradecimentos}

Esta pesquisa não seria possível se não houvesse a contribuição e apoio de várias pessoas e instituições. Especialmente por isto, meus sinceros agradecimentos:

Ao Prof. Dr. Sérgio Sheiji Fukusima, meu orientador, por sua disponibilidade, por todas as horas de supervisão, grupos de estudos e jantar apimentado.

Ao Prof. Dr. José Aparecido da Silva, ao Prof. Dr. Jesus Landeira Fernandes e ao Prof. Dr. Sílvio Morato de Carvalho pelas sugestões oferecidas e discussões durante o exame de qualificação.

Ao Sr. João Garcia Duarte Neto, gerente divisional da EPTV Ribeirão, no período em que se permitiu minha entrada no estúdio da emissora para o primeiro contato com os apresentadores do Jornal Regional.

Aos apresentadores do Jornal Regional: Chico Ferreira, Flávia Chiarello, Paulo Carlim e Kelly Godoy, que gentilmente permitiram as manipulações de suas imagens faciais.

Ao Sr. Paulo César Pereira de Oliveira, presidente do Centro Cultural Orùnmilá de Ribeirão Preto, que cordialmente aceitou que fotografássemos voluntários no recinto.

Aos Senhores Diretores das FABAN, da UNIP e do CEFORP, que permitiram fotografar voluntários nas dependências de suas instituições.

À Kátia Cruvinel Arraes por fotografar as pessoas voluntárias em espaços públicos da cidade e por me ajudar a montar o banco de imagens faciais.

Ao ilustrador Eduardo Baptistão por autorizar o uso de suas caricaturas na capa deste trabaIho.

Aos amigos do Laboratório de Psicofísica e Percepção: Luciana Maria da Silva, Nelson Torro Alves, Kátia Maria Monteiro Rodrigues de Carvalho, Maria Amélia Cesari Quaglia, Lina María Perilla Rodríguez, Leonardo Gomes Bernardino, Bruno Marinho de Souza e Patrícia Consolo, por compartilharem alegrias e tristezas nas árduas, mas sempre muito produtivas discussões em reuniões do grupo de estudo do laboratório, pelo apoio, incentivo e trocas de conhecimento.

Ao Júnior e à Josi pelo café, bolachinhas e conversas de corredor. Aprendi bastante nesses momentos.

Ao amigo César Muniz, que tanto me ensinou sobre tratamento e manipulação de imagens digitais. Nada teria ficado bom se não fosse ele.

Aos meus irmãos Cândi e Beto, que me ajudaram a aliviar e a agüentar momentos difíceis durante $\mathrm{o}$ desenvolvimento da pesquisa. $\mathrm{E}$ à minha mãe pelo apoio incondicional.

Às amigas Carla, Clá, Marô e Dri Caldana, e pelo apoio e momentos divertidos. 
A todas as pessoas que aceitaram ser fotografadas e voluntariamente doaram suas imagens pra formar nosso banco de imagens faciais.

A todos os voluntários que participaram dos experimentos. Em especial ao pessoal do AikiUSP, da $42^{\mathrm{a}}$ e $43^{\mathrm{a}}$ turmas de graduação da Psicologia da FFCLRP-USP.

À CAPES e ao CNPq por financiarem a pesquisa. 
SUMÁRIO

RESUMO 9

ABSTRACT 10

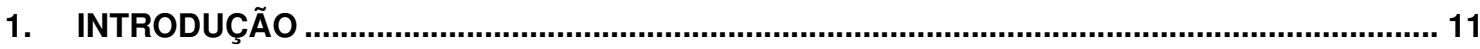

1.2. NEUROBIOLOGIA DO RECONHECIMENTO DE FACES ................................................. 12

1.3. MODELOS DE RECONHECIMENTO DE FACES ...................................................... 13

1.3.1. Relevância dos aspectos faciais para o reconhecimento de faces .................... 14

1.3.2. Hipóteses sobre a codificação de faces ....................................................... 15

1.4. CARICATURAS E OS MODELOS DE RECONHECIMENTO DE FACES.................................. 19

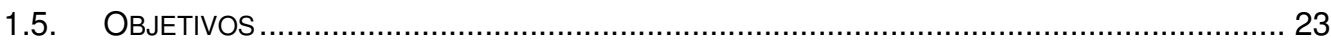

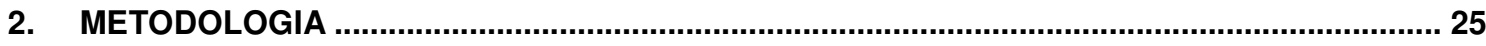

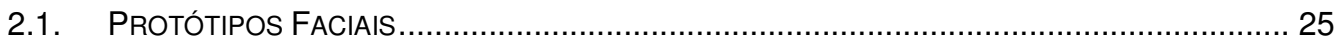

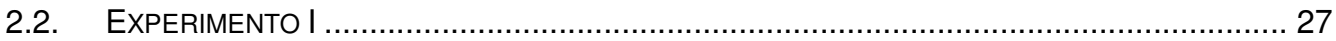

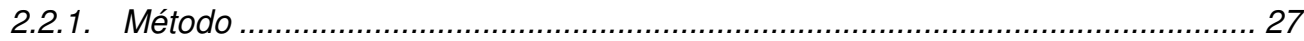

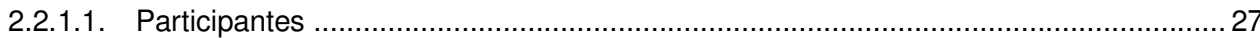

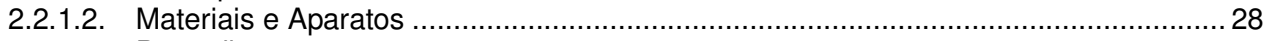

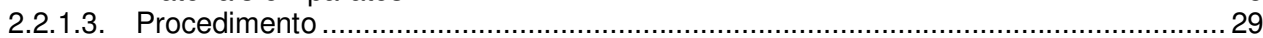

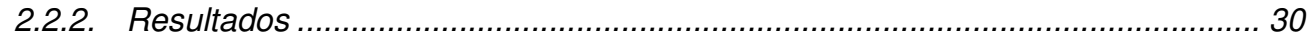

2.2.2.1. Diferença entre as faces e os protótipos ............................................................... 30

2.2.2.2. Julgamento de Similaridade ............................................................................. 33

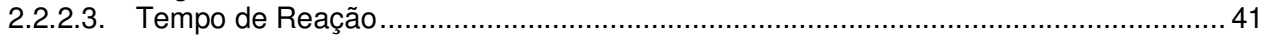

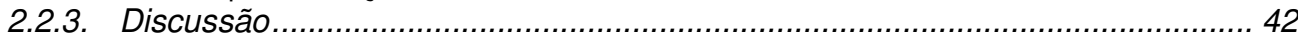

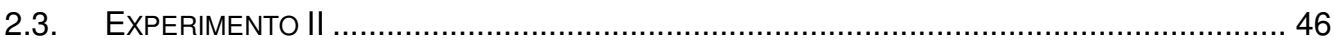

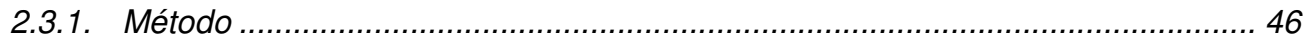

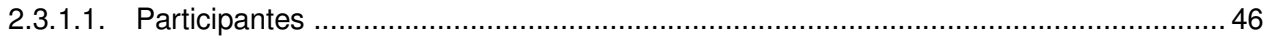

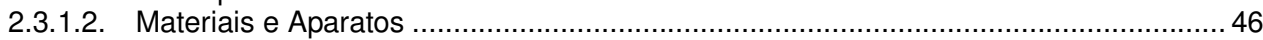

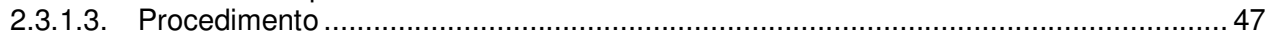

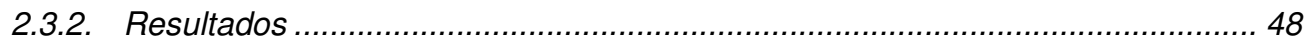

2.3.2.1. Diferença entre os elementos faciais e os protótipos ..................................... 48

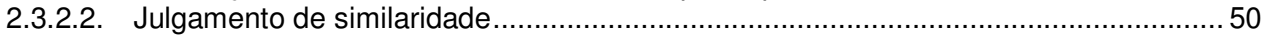

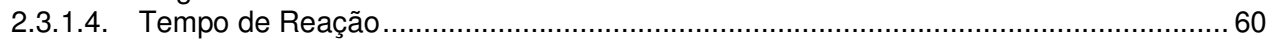

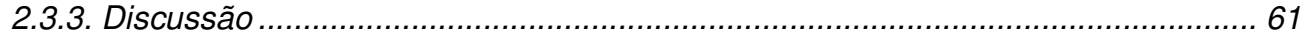

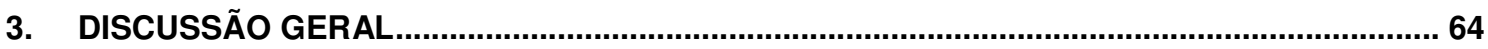

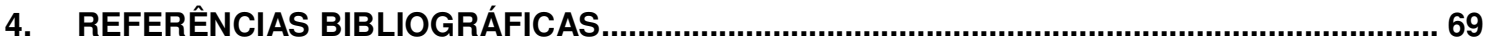

APÊNDICE A - CONFECÇÃO DOS PROTÓTIPOS …............................................................... 72

1. CAPTURA DE IMAGENS FAcIAIS PARA FORMAR O BANCO DE DADOS ............................. 72

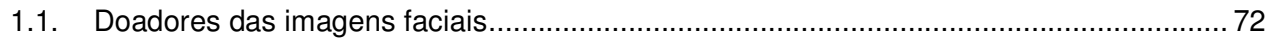

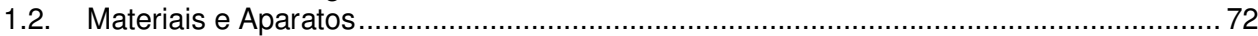

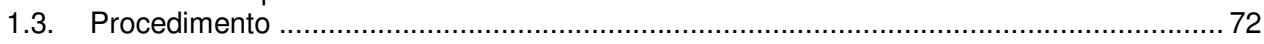

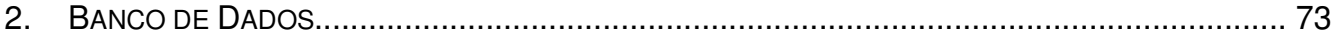

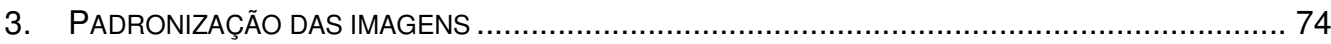

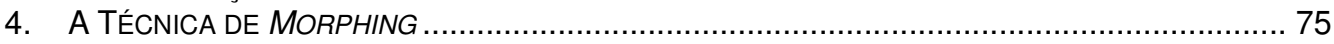

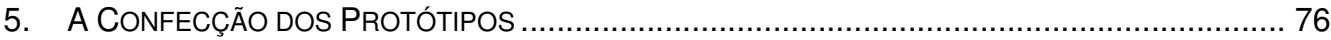

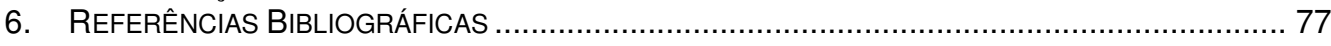

APÊNDICE B - CONFECÇÃO DAS CARICATURAS E ANTI-CARICATURAS ................................ 79

1. DistORÇÕES HoLÍSTICAS: ESTíMULOS PARA O EXPERIMENTO I.................................... 79

2. TÉCNICA DE CAMADAS: ESTÍMULOS PARA O EXPERIMENTO II ..................................... 82

APÊNDICE C - TERMO DE AUTORIZAÇÃO DE USO DA IMAGEM ............................................ 85

APÊNDICE D - TERMO DE CONSENTIMENTO LIVRE E ESCLARECIDO ........................................ 86

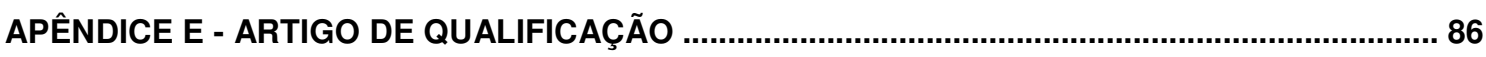

ANEXO A - DOCUMENTO DE APROVAÇÃO DO COMITÊ DE ÉTICA EM PESQUISA ..................... 87 


\section{RESUMO}

A caricatura, uma imagem da face baseada no exagero de suas características peculiares, geralmente é reconhecida tão bem quanto a fotografia da face sem distorções. Para confecção das caricaturas, exageram-se as diferenças entre a imagem original e um protótipo (face média de um grupo de pessoas); e para confecção das anti-caricaturas essas diferenças são atenuadas. O objetivo desta pesquisa foi investigar se existe um grau de exagero "ótimo" para que a caricatura represente a face melhor que a fotografia original. Além disso, investigou-se o papel da percepção holística versus percepção componencial no processo de reconhecimento de faces. Foram geradas seis faces prototípicas, masculinas e femininas, de pessoas da população da região de Ribeirão Preto que se auto-declaram branca, parda e preta. A partir das faces prototípicas, foram gerados dois tipos de caricaturas e anticaricaturas: 1. holística: em que todas as diferenças entre a face original e a prototípica foram manipuladas, 2. parcial: em que somente as diferenças de alguns elementos faciais isolados ou combinados entre a face original e a prototípica foram manipuladas. No Experimento I os estímulos teste foram as caricaturas e anti-caricaturas holísticas. No Experimento II os estímulos foram as caricaturas e anti-caricaturas parciais. Em ambos experimentos as caricaturas e anti-caricaturas foram submetidas a julgamentos de similaridade com a face original previamente memorizada. Os resultados do Experimento I indicaram que a melhor representação da face é a fotografia sem distorção e que, nos casos em que a face é atípica em relação ao protótipo, as caricaturas tendem a ser representações tão fidedignas quanto as fotografias sem distorção. Os resultados do Experimento II apontam para a importância dos elementos peculiares no reconhecimento de faces. Comparando-se os resultados dos Experimentos I e II pode-se afirmar que o processamento de faces se dá predominantemente de forma holística e que a manipulação de elementos peculiares da face reduz mais a similaridade entre a face original e a caricatura (ou anti-caricatura) que a manipulação de elementos não-peculiares. 


\section{ABSTRACT}

A caricature is an exaggeration of distinctive facial features and is generally recognized just as well as an undistorted photograph of a face. Caricatures can be generated by exaggerating the differences between a face and a prototypical face (average face) and an anticaricature can be generated by reducing those differences. The aim of this study was to investigate whether there is a degree of caricaturing that best captures facial likeness. Moreover, we investigated the role of holistic perception versus componential perception in the facial recognition process. Six prototypical faces, three male and three female, were generated by morphing photographs of Brazilian people from the region of Ribeirão Preto-SP of different races: black, white and mixed race. Two types of caricatures and anticaricatures were generated: 1 , holistic: by manipulating of all the differences between a face and the prototypical faces; 2 , partial: by manipulating the differences of isolated or combined features between a face and the prototypical face. The stimuli used in Experiment 1 were the holistic caricatures and anticaricatures. In Experiment 2 the stimuli were the partial caricatures and anticaricatures. In both experiments, subjects were asked to rate the similarity between the caricatures and the anticaricatures and a face previously memorized. The results of Experiment 1 provide evidence that the best representation of the face is a photograph without distortion and that, when the face is atypical, the caricatures seem to be as good as photographs without distortion. The results of Experiment 2 point to the importance of the role of distinctive features in face recognition. Comparing the results of Experiments 1 and 2, we can say that the facial recognition process is predominantly holistic but that the manipulation of distinctive facial elements reduces the similarity judgment more than the manipulation of non-distinctive features. 


\section{INTRODUÇÃO}

Membros de uma espécie com organização social complexa precisam reconhecer uns aos outros para que as interações sociais aconteçam. Na espécie humana, a face é uma das mais importantes chaves do reconhecimento de indivíduos. Além disso, uma série de outras informações que permeiam nossas relações pessoais pode ser encontrada na face. Com essas informações podemos inferir sentimentos e estados de espírito e regular nossas interações sociais através de contato visual e expressões faciais, e identificar e categorizar pessoas de acordo com sua idade e sexo. As mudanças na face também nos trazem informações sobre a fala, há indícios experimentais que a percepção de sons interage com as alterações na forma da boca (McGurk \& MacDonald, 1976).

O ser humano é bom em reconhecer faces, somos capazes de reconhecer centenas de faces e identificá-las apropriadamente. Alguns teóricos afirmam que somos "especialistas em faces" (face experts) (Mondloch, Maurer \& Ahola, 2006; McKone, Kanwisher \& Duchaine, 2006). Essa habilidade implica em codificar e representar faces de forma a serem reconhecidas posteriormente. A sensibilidade de codificar faces e perceber as mínimas diferenças entre elas é que faz das faces a forma ideal para identificar pessoas.

Reconhecimento de faces é um vasto campo de investigação que tem despertado interesse de profissionais das mais diversas áreas como psicologia, computação, antropologia, biologia, neurociências. Suas aplicações são igualmente amplas e interessam, além das teorias em psicologia, ao sistema forense (principalmente quando se faz retrato-falado e na tarefa de identificação do infrator); a sistemas biomecânicos de identificação para proteção de companhias, organizações e países.

Esta pesquisa consiste numa investigação experimental, utilizando os recursos da psicofísica, dos modelos de reconhecimento de faces. Para introduzir a questão que a despertou, serão brevemente apresentadas as bases biológicas do reconhecimento de faces. Logo em seguida, apresentar-se-ão os modelos de reconhecimento de faces e, por último, 
será discutido como esses modelos podem explicar os dados encontrados em estudos que utilizaram caricaturas em tarefas de reconhecimento de face.

\subsection{Neurobiologia do Reconhecimento de Faces}

Dada a importância de reconhecer faces na nossa vida em sociedade, temos uma área cerebral envolvida nesse processo. As evidências de quais as áreas cerebrais recrutadas nesta tarefa são derivadas de estudos com lesões cerebrais e, mais recentemente, de estudos com neuro-imagem.

Estudos com pessoas que sofreram lesão no hemisfério direito demonstram que elas apresentam negligência lateral esquerda. Em alguns casos essa negligência é específica para faces e, conseqüentemente, as pessoas são incapazes de reconhecer a metade esquerda de faces (Bruce \& Young, 1998). Esse achado aponta para a importância do envolvimento do hemisfério direito no reconhecimento de faces. Apoiando essa evidência, nota-se que pessoas destras normais tendem a superestimar a importância da informação da metade esquerda da face (Gilbert \& Bakan, 1973; Bruce \& Young, 1998).

A lesão cerebral no lobo temporal direito, principalmente quando próxima à linha medial do cérebro no giro fusiforme, leva a uma incapacidade de reconhecer faces, denominada prosopagnosia. A maioria das pessoas que têm prosopagnosia sabe que está olhando uma face, mas não faz idéia de para quem está olhando. Elas são incapazes de reconhecer inclusive a própria face no espelho. Entretanto, a capacidade de reconhecer objetos e partes de faces é preservada, o que evidencia que reconhecimento de faces é dissociado do reconhecimento de outros objetos (Michelon \& Biederman, 2003).

A técnica de imagem por ressonância nuclear magnética funcional (do inglês, $f M R I)$ possibilita saber qual a área cerebral recrutada nas mais diversas tarefas. Em pessoas normais, encontrou-se ativação significativamente maior de neurônios na área do giro fusiforme - denominada fusiform face area - quando as pessoas viam faces do que quando viam objetos não-faces (Kanwisher, McDermott \& Chun, 1997), evidenciando que esta área está 
relacionada com o processamento de imagens faciais e não de outros objetos (Grill-Spector, Knouf \& Kanwisher, 2004).

A habilidade de reconhecer faces depende tanto de mecanismos inatos quanto da experiência, começando cedo no desenvolvimento e aprimorando a medida em que se desenvolve. Estudos com bebês com idade média de 43 minutos de vida demonstram o interesse inato por faces (Johnson, Dziurawiec, Ellis \& Morton, 1991). Foram apresentados aos bebês esquemas faciais e não-faciais e esses se detinham mais em esquemas faciais. Provavelmente a vantagem adaptativa desse comportamento é se mostrar interessado em seu cuidador e inspirar cuidados. Além disso, esses resultados indicam que o aprendizado para o futuro reconhecimento de faces começa cedo no desenvolvimento infantil. Experimentos com bebês de dois dias evidenciam que eles olham mais para faces de suas mães que para a de estranhos, provavelmente porque já discriminam a face materna e possuem algum mecanismo de reconhecimento (Bushnell, Sai \& Mullin, 1989). Com o desenvolvimento normal, uma criança entre 10 e 14 anos terá a mesma capacidade de reconhecer faces que um adulto (Campbell \& Tuck, 1995).

\subsection{Modelos de Reconhecimento de Faces}

Como mencionado anteriormente, a face humana é de suma importância para o reconhecimento de indivíduos da nossa espécie. Tão importante que possuímos área cerebral especializada nessa tarefa. Mas dado que faces humanas são iguais em sua essência todos nós possuímos os mesmos elementos faciais como olhos, nariz e boca - perguntase: qual a relevância dos elementos faciais e como eles são codificados e representados na memória para que se possa reconhecer a face posteriormente? As pesquisas em reconhecimento de faces apontam alguns modelos que serão apresentados a seguir. Primeiramente será discutida a relevância do processamento dos elementos faciais de forma isolada, das relações espaciais entre esses elementos e da face como um todo para o reconhecimento de faces. Depois serão descritos alguns outros modelos de como esses elementos são codi- 
ficados e arquivados em memória como, por exemplo, a hipótese do protótipo que pode ser a chave explicativa para a hipótese da peculiaridade e do modelo do espaço multidimensional para faces.

\subsubsection{Relevância dos aspectos faciais para o reconhecimento de faces}

Quando se discute o processo de reconhecimento de faces, uma das primeiras questões é se há diferença entre as informações que cada parte da face fornece para seu reconhecimento. Sendo assim, pergunta-se se a percepção da face se configura como um todo, a partir de seus elementos isolados ou das relações entre eles. Ao pedir que alguém descreva o rosto de uma pessoa conhecida, ela comumente lista um conjunto de elementos como boca, nariz e olhos fazendo menção à forma e a cor desses elementos. Talvez essa listagem seja feita porque há informação semântica e linguagem para descrevê-lo. Ou então porque esses elementos possuem funções sensoriais importantes e estas levariam a uma análise separada de cada um deles. Na vida social humana, os elementos faciais possuem importâncias variadas. O nariz e as orelhas nos trazem poucas informações sociais, mas variações na região dos olhos e da boca carregam informações cruciais sobre estados emocionais. Por exemplo, os músculos ao redor dos olhos nos revelam se um sorriso é falso ou verdadeiro (Ekman, Friesen \& Ellswoth, 1972).

Existem algumas evidências que o padrão facial seria descrito em função das relações espaciais de seus elementos e não dos elementos tomados individualmente. Uma delas é que, quando os elementos da face de uma pessoa são mantidos intactos e se manipula as distâncias entre eles, há uma alteração na aparência que dificulta a identificação. Essa distorção na aparência proporcionada pela variação da distância entre os elementos faciais é uma das dificuldades que surgem quando se reproduzem rostos utilizando-se programas computacionais para desenhar faces, como os utilizados no sistema judiciário (Bruce \& Young, 1998).

Outra grande evidência de que as relações entre os elementos faciais são processadas de maneira diferente dos elementos faciais isolados pode ser encontrada nos experi- 
mentos de Young, Hellanwell e Hay (1987). Eles dividiram faces famosas em duas metades: superior e inferior. A tarefa do sujeito era identificar a quem pertencia cada uma das metades das faces. Quando elas eram apresentadas isoladamente, o julgamento era feito com acurácia. Contudo, quando a metade superior de uma face era combinada com a inferior de outra, tornava-se difícil reconhecer a quem pertencia cada uma das metades. Aparentemente, a percepção da metade superior da face foi modificada pelos elementos da inferior. Entretanto, o efeito da composição só ocorreu quando as duas metades da face estavam perfeitamente alinhadas. Quando as duas metades estavam presentes, mas desalinhadas, a identificação das metades não sofreu interferência uma da outra.

Nossa capacidade de reconhecer pessoas a mais de 30 metros de distância indica que outras características, além dos elementos faciais, devem estar envolvidas no reconhecimento de faces. Nessa distância têm-se apenas informações gerais sobre a face, mas que são suficientes para que o reconhecimento aconteça. Leon Harmon (1973) demonstrou que as pessoas são capazes de identificar faces de famosos mesmo quando a imagem não está bem definida. Ele confeccionou uma espécie de mosaico com peças grandes, algo como uma imagem de baixa resolução da face de Abraham Lincoln e, para quem o conhecia, não houve dificuldade em identificá-lo. Essa observação remete à percepção da face como um todo independente dos elementos faciais, que também é denominada percepção holística ${ }^{1}$ da face.

\subsubsection{Hipóteses sobre a codificação de faces}

- Hipótese do Protótipo

Segundo a hipótese do protótipo, as faces devem ser codificadas em função de protótipos, ou esquemas, resultantes da generalização de faces vistas por uma pessoa. O protótipo facial seria uma imagem ideal armazenada na memória de longo prazo, como a ten-

${ }^{1}$ Do Grego, holos significa todo. Neste contexto, percepção holística significa percepção do todo indecomponível. 
dência central de uma classe, representando a aparência típica de um grupo de pessoas. Cada face nova vista seria representada na memória, não com todos os detalhes, mas segundo as diferenças que têm em relação ao protótipo.

De acordo com essa hipótese, os dados com pesquisa com bebês de dois dias que apontam que estes preferem as faces de suas mães (Bushnell et al.,1989) seria explicado pelo fato das faces materna serem as que eles mais viram, formando seu protótipo facial até então. Os bebês prefeririam, portanto, não as faces de suas mães, mas o protótipo.

Existem evidências neurofisiológicas da existência do protótipo. Como mencionado anteriormente, estudos com ressonância nuclear magnética funcional em humanos têm mostrado que a área facial fusiforme é especializada no processamento de faces. Loffler, Yourganov, Wilkinson e Wilson (2005) manipularam aspectos geométricos de faces distanciando os elementos faciais em relação a uma face prototípica e descobriu-se maior ativação nessa área cerebral com o aumento dessa distância.

- Hipótese da Peculiaridade (distinctiveness)

A hipótese da peculiaridade propõe que os objetos devem ser representados na memória em forma de esquemas com ênfases nas suas propriedades distintas. Ou seja, os aspectos peculiares, distintivos do objeto são codificados e representados na memória. Segundo essa hipótese, as faces, bem como outros objetos, seriam representados na memória em função de seus aspectos peculiares. E, se os aspectos distintos são notados, a face pode ser diferenciada de outra e reconhecida quando vista novamente.

A hipótese da peculiaridade pressupõe o conhecimento prévio da categoria específica que, em faces, seria adquirido pela experiência com as faces vistas pelo indivíduo. A teoria prediz que uma face típica, ou seja, uma face com muitos elementos comuns às faces vistas, seria facilmente confundida com outras. Já uma face peculiar seria identificada mais facilmente. Os efeitos da peculiaridade podem ser revelados em diferentes tarefas envolvendo faces. Por exemplo, em estudos com faces famosas notou-se que faces com caracte- 
rísticas peculiares são reconhecidas mais rapidamente que as faces de aparência típica (Bruce \& Young, 1998).

O efeito da peculiaridade poderia ser explicado em função da memória esquemática da categoria. Desta forma, faces peculiares seriam mais fáceis de acessar a memória específica porque é menos similar a outras faces (Light, Kayra-Stuart \& Hollander, 1979). Ou seria explicada em função da familiaridade, ou seja, quanto menos familiar a face, mais fácil de ser codificada (Bartlet, Hurry \& Thorley, 1984). Uma terceira explicação plausível para o efeito da peculiaridade provém dos resultados dos estudos de Valentine e Bruce (1986). Eles conduziram experimentos de categorização entre face/não-face com rostos de famosos que revelam que faces peculiares são categorizadas como "face" mais lentamente que faces típicas. Os autores propõem a explicação da peculiaridade segundo o modelo do protótipo. Desse modo, as faces são armazenadas em função da série de transformações necessárias para igualar a face ao protótipo, ou seja, a diferença entre a face e o protótipo.

\section{- Modelo do Espaço Multidimensional}

Segundo a hipótese da prototipicidade (prototypicality hypothesis), as faces são organizadas na memória num espaço multidimensional com a face prototípica localizada em seu centro. Quanto maior a diferença entre uma face e o protótipo, maior a distância do centro desse espaço. Desta forma, prototipicidade está diretamente relacionada com similaridade, ou seja, quanto mais similares são as faces, mais próximas umas das outras. Esse espaço multidimensional pode ser medido pedindo que pessoas façam todos os pares de similaridade possível entre um grupo de imagens de faces e submetendo os resultados ao tratamento estatístico de escalonamento multidimensional (multidimensional scaling - MDS). Por meio de MDS pode-se encontrar a configuração de pontos no espaço multidimensional em que a distância entre os pontos está relacionada com a similaridade (ou dissimilaridade) julgada. Como conseqüência, faces típicas estariam centralizadas no espaço e faces com características ou configurações peculiares estariam distantes do protótipo. Esse modelo foi validado por Valentine (1991) e prediz que quanto maior a similaridade de uma face com a 
face prototípica, mais típica ela é e mais perto ela está do centro do espaço multidimensional; por outro lado, quanto mais dissimilar, mais atípica e mais afastada do centro do espaço multidimensional.

Existem dois modelos distintos para a codificação de faces no espaço multidimensional: 1. modelo da codificação da face a partir de uma norma (norm-based coding model); 2. modelo baseado em exemplares (exemplar-based model). O modelo da codificação a partir de uma norma prediz que as faces são decodificadas de acordo com o desvio que essas possuem em relação ao protótipo, este localizado no centro do espaço multidimensional (Figura 1.3.1 A). Propõe-se que há apenas um protótipo derivado de todas as faces já vistas e não um para cada classe de faces. A representação de cada face, segundo esse modelo, seria em forma de vetores partindo do centro do espaço multidimensional e as distâncias de similaridade entre as faces seriam distâncias vetoriais. Por outro lado, o modelo baseado em exemplares não supõe a existência de um protótipo (Figura 1.3.1 B). As faces são consideradas como pontos no espaço multidimensional e não como vetores e as distâncias de similaridade entre elas seriam distâncias euclidianas. A origem do espaço multidimensional seria apenas o ponto de maior densidade entre os exemplares.
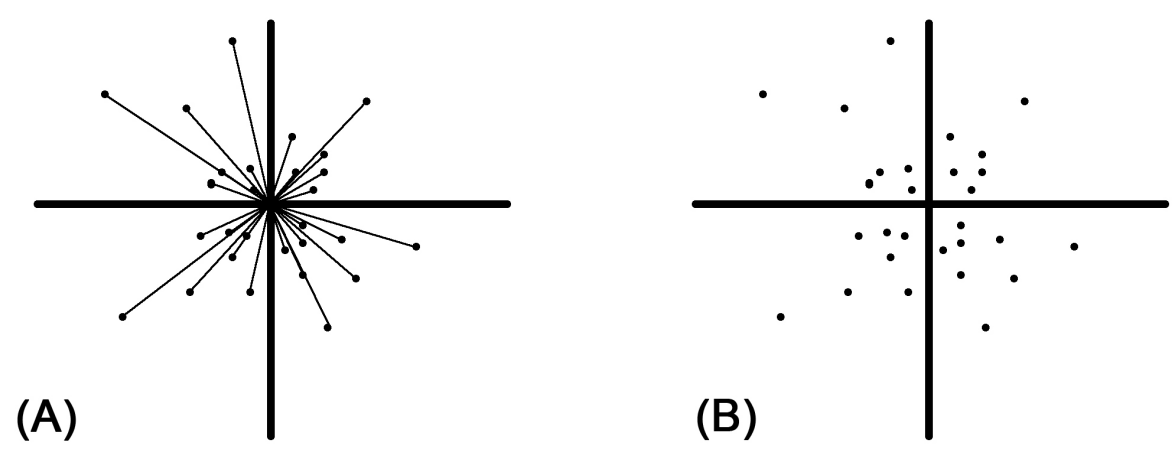

Figura 1.3.1: Representações bidimensionais para ilustrar o modelo do espaço multidimensional. (A) é uma representação da codificação baseado na norma. Cada ponto representa uma face previamente vista localizado no espaço $n$-dimensional. A origem dos pontos representa o protótipo. A similaridade entre duas faces é dada pela distância vetorial entre as faces. (B) é uma representação bidimensional ilustrativa do modelo do espaço multidimensional baseado nos exemplares. Assim como na Figura $A$, cada ponto representa uma face já vista localizada no espaço $n$-dimensional. $A$ origem dos pontos é arbitrária e representa a o ponto de maior densidade de faces. A similaridade entre as faces é determinada pela distância entre dois pontos e é independente do ponto de origem. 
O modelo do espaço multidimensional pode ser utilizado para entender fatores como peculiaridade, etnia e inversão (de cabeça para baixo) da face atuam no reconhecimento de faces, sugerindo que eles sejam agregados. O conhecido "viés da etnia" é causado pela diferença entre a etnia do observador e da face julgada, sendo que faces da mesma etnia do observador são reconhecidas mais facilmente que faces de etnias diferentes da dele ou por ele desconhecidas (Shepherd, 1981 apud Valentine, 1991). Em outras palavras, faces de etnias diferentes da do sujeito tendem a ser confundidas. Uma das explicações para esse viés propõe interação entre etnia e peculiaridade, argumentando-se que, quando se trata de reconhecer faces alheias à da etnia do observador, este teria a dificuldade de assimilar os elementos peculiares presentes. Isto ocorreria por não existir experiência suficiente com uma determinada população para se identificar o que é peculiar em apenas uma das faces (Valentine \& Endo, 1992). Ou seja, não se tem um protótipo bem definido para que se possa comparar e decidir o que a face tem de peculiar. Ao se aumentar o contato com uma etnia diferente, passa-se a identificar melhor a face. A explicação hipotética para esse fato é que o contato com as faces de outra etnia aumenta a versatilidade do protótipo já existente e esse passa a ser aplicável à nova etnia.

Chiroro e Valentine (1995) demonstraram como a etnia pode atuar no reconhecimento de faces. Eles rodaram experimentos com estudantes negros que tinham algum contato com faces de brancos e observaram que eles tiveram desempenho pior ao reconhecer faces brancas que ao reconhecer faces negras. Entretanto, os negros que tinham maior contato e reconheciam com mais facilidade as faces brancas eram piores em reconhecer as faces da própria etnia. Esses resultados favorecem o modelo do espaço multidimensional baseado na norma (norm-based coding) para faces apontando para a plasticidade do protótipo.

\subsection{Caricaturas e os modelos de reconhecimento de faces}

Até aqui se apresentou a relevância do reconhecimento de faces para espécie humana, bem como quais as possíveis áreas cerebrais envolvidas nessa tarefa. Também fo- 
ram descritos alguns modelos e hipóteses de como as faces são codificadas para serem reconhecidas, dando ênfase ao modelo do espaço multidimensional. Neste tópico serão apresentados alguns experimentos, e as possíveis explicações de seus resultados, que foram cruciais para traçar os objetivos desta pesquisa. Nos experimentos a seguir discute-se como as caricaturas são reconhecidas, assim como qual seria o melhor modelo para explicar esse efeito.

A caricatura é definida como uma imagem construída baseando-se nos exageros das características físicas de uma pessoa (Fonseca, 1999). Há evidências experimentais que ela funciona como um super-retrato (superportrait) (Rhodes, Brennan \& Carey, 1987), ou seja, uma representação mais fidedigna da face da pessoa que sua fotografia sem qualquer manipulação.

Uma explicação para o funcionamento da caricatura como super-retrato — que nesta pesquisa denominou-se também como vantagem da caricatura - baseia-se na hipótese da peculiaridade. O que é peculiar na face é determinado pela comparação entre uma determinada face e o protótipo. Como a imagem caricaturada dá ênfase às características peculiares da face, esta estaria mais próxima ao que se tem armazenado na memória do que a imagem original.

A conveniência de se usar caricaturas como estímulo teste para investigar a hipótese da peculiaridade e o modelo do espaço multidimensional residem no fato de que, com a caricatura, é possível variar a peculiaridade de uma mesma face em relação ao protótipo. Desta forma, pode-se manipular a tipicidade da face de uma pessoa e verificar se a manipulação interfere na sua identificação.

As evidências experimentais para a vantagem da caricatura são encontradas no trabalho desenvolvido por Rhodes et al. (1987). Nesse trabalho, elas testaram a hipótese da peculiaridade e da caricatura como super-retrato utilizando caricaturas feitas por meio de um programa computacional desenvolvido por Brennan (1985). Por meio dele, comparou-se uma face alvo com o protótipo (que as autoras chamaram de face normativa - norm face) e aumentando-se as diferenças entre as duas faces obtiveram a caricatura. Se essas diferen- 
ças métricas entre os elementos da face alvo e da face normativa fossem amenizadas, obter-se-ia a anti-caricatura. O grau de aumento ou de diminuição dessas diferenças na face alvo para se obter uma caricatura ou uma anti-caricatura respectivamente é definido pela proporção da diferença entre a face alvo original e a face normativa. Os resultados dos experimentos de Rhodes et al. (1987) indicaram que desenhos caricaturados são identificados mais rapidamente que o desenho da face sem nenhuma distorção. Além disso, foi demonstrado que as caricaturas são julgadas mais similares às faces das pessoas que as suas respectivas faces desenhadas e estas últimas mais similares às faces das pessoas que as suas respectivas anti-caricaturas. Esses resultados apóiam a hipótese da existência da caricatura como super-retrato e a hipótese da peculiaridade no reconhecimento de faces.

Depois do programa computacional desenvolvido por Brennan (1985), dois outros pesquisadores, Benson e Perret (1991a; 1991b) desenvolveram uma técnica para se gerar caricaturas com qualidade fotográfica e testaram se caricaturas de pessoas famosas confeccionadas com essa técnica teriam o mesmo efeito que caricaturas em forma de desenho. Os resultados destes experimentos sugeriram que a vantagem da caricatura não é restrita ao desenho. Uma explicação mais detalhada da técnica, haja vista que foi utilizada nos experimentos propostos, pode ser encontrada no Apêndice B.

Lee, Byatt e Rhodes (2000) também fizeram experimentos utilizando caricaturas com qualidade fotográfica. Os sujeitos tinham que identificar caricaturas, fotografias sem distorções e anti-caricaturas de pessoas famosas. O tempo de reação foi medido e mais uma vez encontrou-se a vantagem da caricatura sobre a fotografia original (sem manipulações) na tarefa de identificação.

Como são encontrados na literatura vários graus de exagero facial que facilitam o reconhecimento de faces, Rhodes, Byatt, Tremewan e Kennedy (1996) investigaram se a peculiaridade inicial da face influenciaria o efeito da caricatura, sendo esta a causa dessas divergências. Nesse experimento, os sujeitos aprenderam os nomes de pessoas desconhecidas cujas fotografias variavam em peculiaridade. Depois foram testados reconhecimentos de caricatura, anti-caricatura e fotografias sem distorções. Estes pesquisadores fizeram ex- 
perimentos com estímulos sob forma de desenhos e fotografias. As faces peculiares foram reconhecidas mais facilmente que as faces menos peculiares. E as caricaturas, em forma de desenho ou fotografia, foram reconhecidas pelo menos tão facilmente quanto as faces originais e estas últimas, mais facilmente reconhecidas que as anti-caricaturas. Os resultados desse experimento, contudo, não evidenciaram a interação entre a peculiaridade inicial da face e a caricatura, refutando a hipótese inicial. Os autores sugeriram que a caricatura em forma de desenho funcionaria como super-retrato e que a fotografia caricaturada seria julgada tão facilmente quanto a sua correspondente original.

Um fator que poderia influenciar o reconhecimento de faces por meio de caricaturas são as diferenças entre as etnias das faces observadas, do observador e do protótipo. Byatt e Rhodes (1998) investigaram a influência da etnia na percepção de faces e caricaturas. Eles compararam o reconhecimento de faces entre chineses e europeus caucásicos e obtiveram um protótipo para cada etnia. As caricaturas e anti-caricaturas foram feitas a partir do protótipo da mesma etnia da face-alvo, ou a partir do protótipo da face de etnia diferente. Os resultados indicaram que as caricaturas cujo protótipo é da mesma etnia foi mais facilmente reconhecida, favorecendo o modelo do espaço muldimensional baseado nos exemplares ( $e$ xemplar-based model).

Em síntese, a vantagem da caricatura parece estar relacionada com três tópicos:

1. Facilitação da associação entre a face a ser reconhecida e a face memorizada;

2. Fornecimento de pistas sobre a pessoa (gesto, expressão, pose) pelo caricaturista que a fotografia não fornece;

3. Mimetização da forma de decodificação de faces por meio da caricatura.

Ainda não há um consenso sobre como estes tópicos explicam porque a caricatura funciona como super-retrato, nem como a hipótese da peculiaridade e o modelo do espaço multidimensional se aplicam ao reconhecimento de faces. É provável que a face seja codificada e armazenada na memória em função de suas peculiaridades e que a caricatura mime- 
tize esse processo. E a vantagem da caricatura parece depender de fatores como etnia, gênero, peculiaridade da face e o seu grau de exagero.

\subsection{Objetivos}

As caricaturas se têm mostrado um estímulo eficaz para investigar os modelos de codificação de faces. Somando-se à elucidação desses modelos, ainda resta investigar quais aspectos peculiares são armazenados em memória, se separadamente, se em função das relações espaciais entre eles ou se de forma holística. E se, a partir daí, para confeccionar uma caricatura deve-se exagerar todos os elementos da face ou se basta exagerar apenas um ou outro elemento ou a combinação entre eles. Superpondo-se a esta questão, restam fatores adicionais como sexo, etnia e idade que interfeririam na vantagem da caricatura e conseqüentemente no processo de reconhecimento de faces.

Apesar da literatura indicar a vantagem da caricatura sobre imagem original no reconhecimento de faces (Rhodes et al., 1987, Lee et al. 2000), os autores discordam sobre o grau que os elementos faciais devem ser exagerados para que a caricatura tenha o seu efeito maximizado. Algumas investigações revelam que a eficácia da caricatura no reconhecimento de faces varia de face para face (Benson \& Perret, 1991b).

Tomando-se esses fatos, esta pesquisa teve como objetivo geral, considerando a influência étnica numa amostra da população brasileira, determinar quais elementos faciais devem ser manipulados para que haja vantagem da caricatura, bem como qual o grau de exagero que uma caricatura deve apresentar para que possa ser classificada como um super-retrato. Em pormenores, esta pesquisa foi desenvolvida com os seguintes objetivos específicos:

1. Criação de um banco de dados de faces de brasileiros.

2. Gerar faces prototípicas masculinas e femininas de jovens adultos (entre 18 e 30 anos) a partir de amostras da população brasileira e investigar a influência de uma etnia miscigenada na determinação de um protótipo facial. 
3. Investigar a relação destes protótipos de diferentes cores/raça com as caricaturas.

4. Investigar qual o grau de exagero de faces em relação a essas faces prototípicas para que a vantagem da caricatura seja estabelecida.

5. Investigar se o reconhecimento de faces por meio de caricaturas necessita que toda face seja exagerada (percepção holística), como no modelo de caricatura computacional descrito por Brennan (1985), ou se apenas o exagero de alguns elementos faciais isolados seria suficiente.

Para atingir estes objetivos foram planejados dois experimentos. No Experimento I, o grau uma imagem deve ser caricaturada para que a vantagem da caricatura com qualidade fotográfica prevaleça sobre a fotografia da face original e que influência diferentes protótipos têm nos julgamentos de similaridade das caricaturas foram investigados. Os estímulos teste foram caricaturas e anti-caricaturas holísticas (todos os elementos faciais foram manipulados simultaneamente) de quatro diferentes faces confeccionadas a partir de três protótipos faciais da população brasileira em 20 graus de exagero. No Experimento II, foi investigado se a vantagem da caricatura acontece quando os elementos faciais internos são manipulados isoladamente ou combinados. Para isso, foram utilizadas caricaturas e anti-caricaturas obtidas manipulando-se os elementos faciais internos separadamente ou combinados. As caricaturas e anti-caricaturas, em ambos os experimentos, foram apresentadas a observadores para que julgassem, por estimação de categoria, quanto cada uma das imagens apresentadas se pareciam com a pessoa conhecida. 


\section{METODOLOGIA}

\subsection{Protótipos Faciais}

Protótipos faciais (também denominados faces prototípicas, face média ou face normativa) são imagens de faces que possuem a aparência típica de um grupo de pessoas, podendo caracterizá-las em categorias específicas como gênero, idade e cor raça². Pesquisas em percepção de faces sugerem que tais protótipos são incorporados à memória por aprendizagem e generalização e que elas são importantes tanto nos processos de julgamentos perceptuais e de reconhecimento de faces quanto nas determinações de atitudes e relações sociais.

Para compreender melhor como esses processos funcionam, foram gerados seis protótipos, três femininos e três masculinos, a partir de amostra da população brasileira da região de Ribeirão Preto com idade entre 18 e 30 anos, segundo sua declaração de cor/raça (branco, preto ou pardo) utilizando a técnica de morphing (para mais detalhes sobre a técnica de confecção dos protótipos consulte o Apêndice A). Cada um dos protótipos foi obtido pela fusão de 64 faces e podem ser observados na Figura 2.1.1. Os protótipos faciais foram validados e indicam pertencer a cada uma das três categorias de cor/raça, como descrito em forma de artigo no Apêndice $E$.

\footnotetext{
${ }^{2}$ No Brasil utiliza-se o termo raça como sinônimo de cor denotando um conjunto de características morfológicas que identificam um grupo de indivíduos. Não se utiliza o termo raça no sentido biológico de subespécie, nem como nos padrões norte-americanos em que raça denota origem (Petruccelli, 2002; Osório, 2003; Oliveira, 2004; Rumjanek, 2004; Pena, 2005). O Instituto Brasileiro de Geografia e Estatística - IBGE - utiliza cinco categorias para definir cor/raça: branco, preto, pardo, amarelo e indígena.
} 


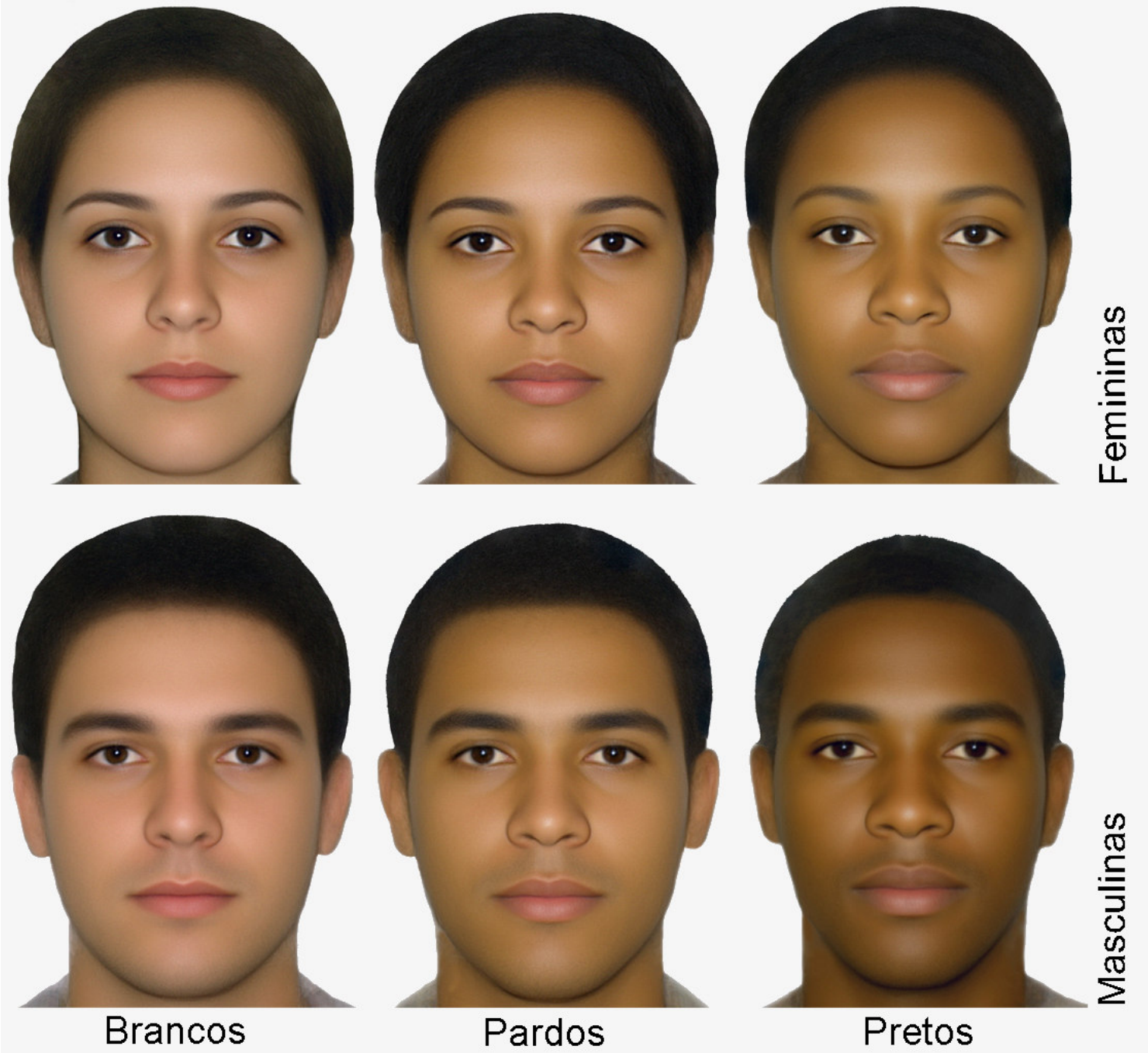

Figura 2.1.1: Protótipos faciais compostos por faces masculinas e femininas de pessoas que autodeclararam como brancos, pardos e pretos. 


\subsection{Experimento I}

Nos estudos em que caricaturas e anti-caricaturas foram utilizadas para investigar os modelos de processamento e reconhecimento de faces encontrou-se que caricaturas são julgadas como mais semelhantes à pessoa que se pretende retratar do que anti-caricaturas ou a fotografia original (Rhodes et al., 1987 e Lee et al., 2000).

Na literatura (Rhodes et al., 1987 e Rhodes et al., 1996, Lee et al., 2000, Benson \& Perret ,1991a, b) sugere-se que: 1. para que essa vantagem seja verificada, uma face deve ser caricaturada com exagero em torno de $16 \%$ quando a figura é em forma de traço (Rhodes et al., 1987) e em torno de $5 \%$ quando a imagem é com qualidade fotográfica (Benson \& Perret, 1991b); 2. faces muito caricaturadas (mais que 50\% de exagero) parecem prejudicar a identificação do indivíduo retratado. Nesses estudos, os protótipos utilizados como base para se confeccionar as caricaturas foram provenientes de amostras de pessoas da mesma etnia que a face caricaturada.

Com este experimento, propõe-se: 1. investigar se há vantagem da caricatura com qualidade fotográfica quando esta foi confeccionada a partir de diferentes protótipos da população brasileira; 2. investigar quanto se deve exagerar uma face para que existam as vantagens da caricatura sobre a fotografia original.

\subsubsection{Método}

\subsubsection{Participantes}

Trinta pessoas, sendo 15 homens e 15 mulheres, entre 18 e 43 anos (média 25,1 e desvio padrão 7,1 anos), brasileiras e ingênuas quanto ao objetivo da pesquisa participaram do experimento em caráter voluntário. Dentre elas, 27 se auto-declararam brancos, 2 pardos e 1 preto. Antes do início da sessão experimental, os participantes leram e assinaram o termo de consentimento livre e esclarecido (Apêndice D) conforme aprovação do Comitê de Ética em Pesquisa da FFCLRP- USP (carta de aprovação no Anexo A). 


\subsubsection{Materiais e Aparatos}

Um microcomputador Pentium $\mathrm{IV}^{\circledR}$, com processador de $3 \mathrm{GHz}$ e memória RAM de 1Gb, acoplado a um monitor de 19" (da marca $L^{\circledR}{ }^{\circledR}$, modelo Flatron ez T910b) foi utilizado para editar as imagens, os vídeos e apresentar os estímulos.

Programa computacional SuperLab Pro ${ }^{\circledR}$ versão 2.0.4 da Cedrus $^{\circledR}$ foi utilizado na apresentação dos estímulos e coleta de dados (maiores informações sobre o software em: http://www.cedrus.com).

Fotografias frontais da face de quatro apresentadores de um telejornal local foram tiradas no estúdio da TV, com a autorização deles, seguindo o mesmo procedimento utilizado para fotografar imagens do banco de dados (ver Tópico 1 do Apêndice A). Os apresentadores do telejornal foram escolhidos por serem pessoas conhecidas pela população da região onde os dados do experimento foram coletados. Eles se auto-declararam brancos e têm entre 29 e 40 anos.

Caricaturas e anti-caricaturas (em formato bitmap —bmp, com tamanho de $600 \times 434$ pixels e resolução de $72 \mathrm{dp}$ i) dessas faces foram geradas pela técnica de morphing utilizando-se o programa computacional Morph Man v4 fabricado pela Stoik ${ }^{\circledR}$ (informações em http://www.stoik.com). Para cada face, foram feitas três séries de caricaturas e anticaricaturas holísticas, baseando-se nos três protótipos (de mesmo gênero da face) previamente gerados. Nas caricaturas, aumenta-se a diferença da forma entre as faces e os protótipos, enfatizando as características peculiares face, já nas anti-caricaturas essas diferenças são diminuídas, atenuando as características peculiares da face e aproximando a forma da face à do protótipo. Aspectos como cor e textura não foram manipulados na confecção das caricaturas nem da das anti-caricaturas. Os estímulos foram gerados em vinte diferentes graus de exagero (de 5 em $5 \%$, variando entre $-100 \%$ e $+100 \%$, sendo que o sinal negativo indica anti-caricatura e o sinal positivo indica caricatura) totalizando, para cada uma das quatro faces, 121 estímulos, sendo 60 anti-caricaturas, a face verossímil e 60 caricaturas (informações mais detalhadas sobre como os estímulos foram gerados podem ser encontradas no Apêndice B). 
Uma filmadora modelo Handcam Sony ${ }^{\circledR}$ DCR DVD405, acoplada a um conversor de sinais de cores do sistema Pal-M para o NTSC, foi utilizada para a captura das transmissões do telejornal local. O software Windows Movie Maker ${ }^{\circledR}$ foi utilizado para editar os vídeos e, para a apresentação destes, utilizou-se o Windows Media Player ${ }^{\circledR}$. Foram registradas duas horas de telejornal local (sem intervalo) e ao final da edição dos vídeos, obteve-se quatro filmes de um minuto e meio de duração para cada um dos quatro apresentadores, sendo dois homens e duas mulheres. Esses filmes foram utilizados na tarefa de memorização da face e caracterizam a situação natural em que as faces dos jornalistas são comumente memorizadas.

\subsubsection{Procedimento}

Após concordar com os termos do experimento e declarar sua cor/raça segundo as categorias do IBGE, os participantes foram submetidos à sessão experimental composta por quatro blocos, um para cada face, de até 10 minutos cada. Eles fizeram o experimento em situação binocular, sentados a $50 \mathrm{~cm}$ do monitor digital. Cada bloco consistia em duas tarefas: a memorização de uma face e logo em seguida o julgamento da similaridade entre a face memorizada e o estímulo apresentado. A apresentação dos blocos foi em ordem aleatória.

Memorização da face: a imagem do apresentador que seria julgado naquele bloco foi apresentada e perguntou-se se o participante o conhecia previamente. Logo em seguida, o participante assistiu ao vídeo de um minuto e meio cuja tarefa foi memorizar a face com o máximo de detalhes possível. Os filmes do telejornal local foram utilizados na tarefa de memorização da face por caracterizarem a situação natural em que as faces dos jornalistas são comumente memorizadas. A tarefa de memorização foi feita numa sala iluminada, com a presença do experimentador.

Julgamento de similaridade: feita a memorização, o participante fez os julgamentos de similaridade entre a face memorizada e as caricaturas e anti-caricaturas. Ele deveria julgar imagens distorcidas e não distorcidas da face memorizada atribuindo a cada estímulo 
um valor conforme o grau de semelhança percebido. Esse julgamento deveria ser expresso segundo uma escala de números inteiros entre 1 e 7 , sendo que o valor 1 indicava que o estímulo apresentado não se parece em nada com a face memorizada na primeira tarefa e o valor 7 indicava que é idêntica. Para dar as respostas o participante utilizou o teclado numérico do computador. Dadas as instruções, as 60 caricaturas, 60 anti-caricaturas e a face verossímil foram apresentadas em fundo preto e em ordem aleatória na tela do monitor. Cada estímulo foi apresentado por um segundo e meio, seguido pela tela que continha a escala numérica de julgamento em que o participante deveria emitir sua resposta com tempo de apresentação livre. Entre uma imagem e outra houve uma tela de descanso de $500 \mathrm{~ms}$ e no final de cada bloco o participante poderia fazer uma pausa. Cada participante fez a memorização e julgamento de similaridade das faces dos quatro apresentadores, formando-se assim, um grupo de 30 pessoas dependentes em relação às fotografias julgadas.

\subsubsection{Resultados}

Dentre os 30 participantes, 23 declararam conhecer a Face A antes da tarefa de memorização, 23 declararam conhecer a Face B, 19 conheciam a Face C de antes do experimento e 10 conheciam a Face $\mathrm{D}$. As diferenças que cada face tem em relação aos três protótipos de amostras da população brasileira, os julgamentos de similaridade e o tempo que o participante levou para emitir sua resposta (tempo de reação) foram analisados e se encontram detalhados nos tópicos seguintes.

\subsubsection{Diferença entre as faces e os protótipos}

As áreas da diferença entre as faces dos jornalistas e os três protótipos derivados de amostras da população brasileira foram estimadas sobrepondo-se as linhas dos contornos do rosto, testa, cabeça, orelhas, boca, nariz, olhos e sobrancelha da face original e os contornos correspondentes de cada um dos protótipos. Essas áreas foram calculadas em $\mathrm{mm}^{2}$ (as imagens tinham 434x600 pixels de tamanho com resolução de 72 dpi) e podem ser observadas na Figura 2.2.1. As áreas da diferença das Faces $A, B$ e $C$ são menores quando 
comparadas ao protótipo da cor branca que quando comparadas ao de cor parda e estas menores que quando comparadas ao de cor preta. Destas, a Face B é a que possui maior diferença em relação ao protótipo de cor branca. Para a Face $D$, a área da diferença é menor quando comparada ao protótipo de cor parda, seguido pelo de cor preta e a maior diferença é em relação ao de cor branca (Tabela 2.2.1).

Tabela 2.2.1: Áreas (em $\mathrm{mm}^{2}$ para imagens com $434 \times 600$ pixels de tamanho e resolução de $\left.72 d p ı\right)$ das diferenças entre cada uma das faces e os três protótipos.

\begin{tabular}{l|ccc}
\hline & $\begin{array}{c}\text { Protótipo de cor } \\
\text { branca }\end{array}$ & $\begin{array}{c}\text { Protótipo de cor } \\
\text { parda }\end{array}$ & $\begin{array}{c}\text { Protótipo de cor } \\
\text { preta }\end{array}$ \\
\hline Face A & 3352,4 & 4215,8 & 5751,0 \\
Face B & 5086,2 & 6690,8 & 8657,3 \\
Face C & 3028,8 & 3283,2 & 3734,4 \\
Face D & 6265,6 & 5769,1 & 6019,2 \\
\hline
\end{tabular}




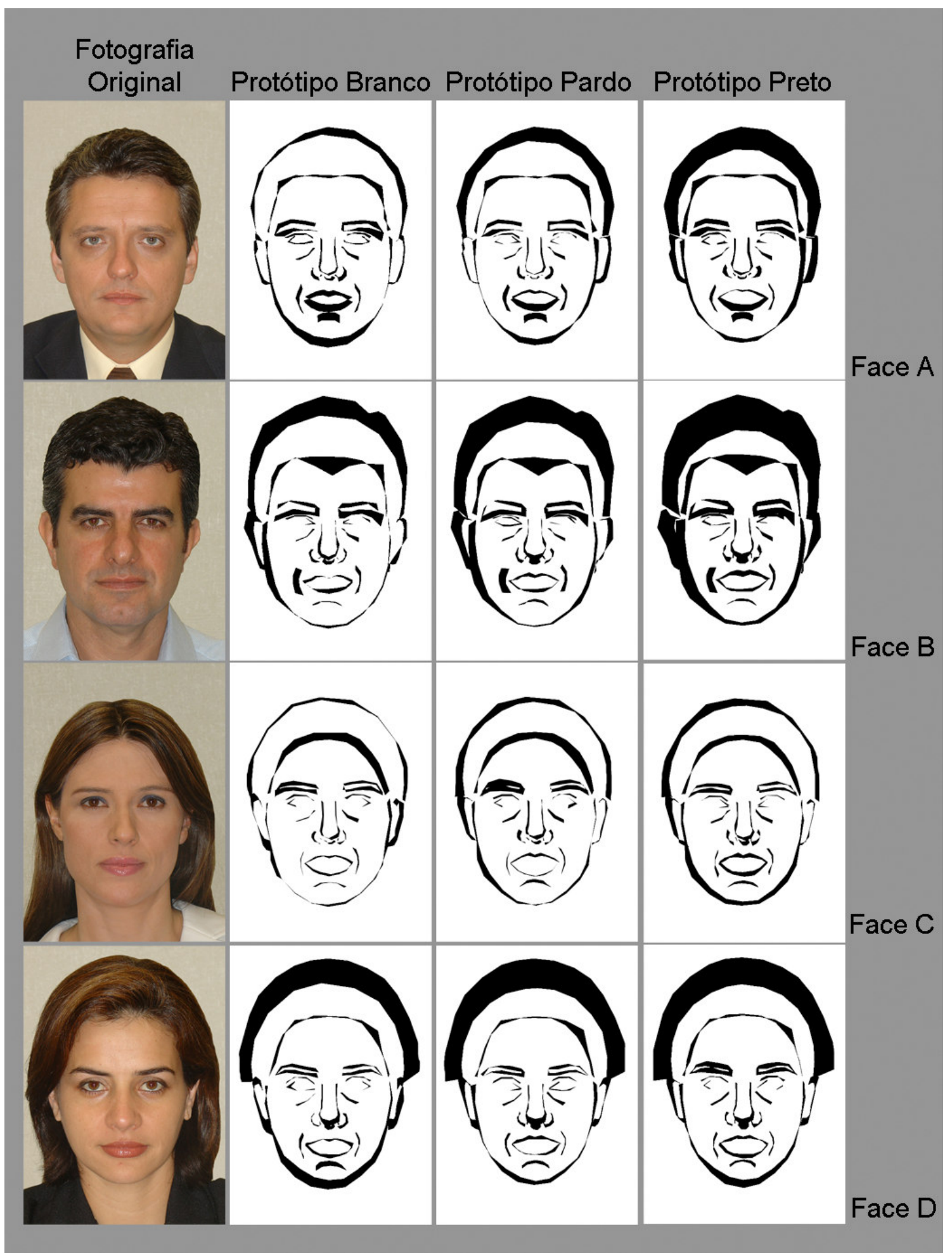

Figura 2.2.1: Em preto têm-se a área da diferença entre cada uma das faces originais e os três protótipos confeccionados com amostras da população brasileira e categorizados segundo sua cor/raça. As imagens originais têm $434 \times 600$ pixels de tamanho e resolução de 72 dpi. 


\subsubsection{Julgamento de Similaridade}

Os dados gerados pelo experimento na tarefa de julgamento de similaridade são qualitativos no nível ordinal. Isso acarreta algumas desvantagens como não informar a amplitude das categorias de julgamento e a impossibilidade de cálculo de alguns parâmetros estatísticos como média e desvio-padrão. Por isso, os dados foram convertidos para escala intervalar seguindo o procedimento indicado por Guilford (1954). Desta forma, as freqüências relativas dos julgamentos em cada uma das categorias foram acumuladas e ajustadas à curva normal reduzida, obtendo-se assim a estimativa da extensão das categorias de julgamento em nota z. As médias e os desvios-padrão para cada um dos exageros em função de cada um dos protótipos das três cores foram calculados. Essas médias, com os respectivos erros-padrão da média foram traçados em função da distorção das quatro imagens faciais (Figura 2.2.2 A, B). 


\section{Face A}

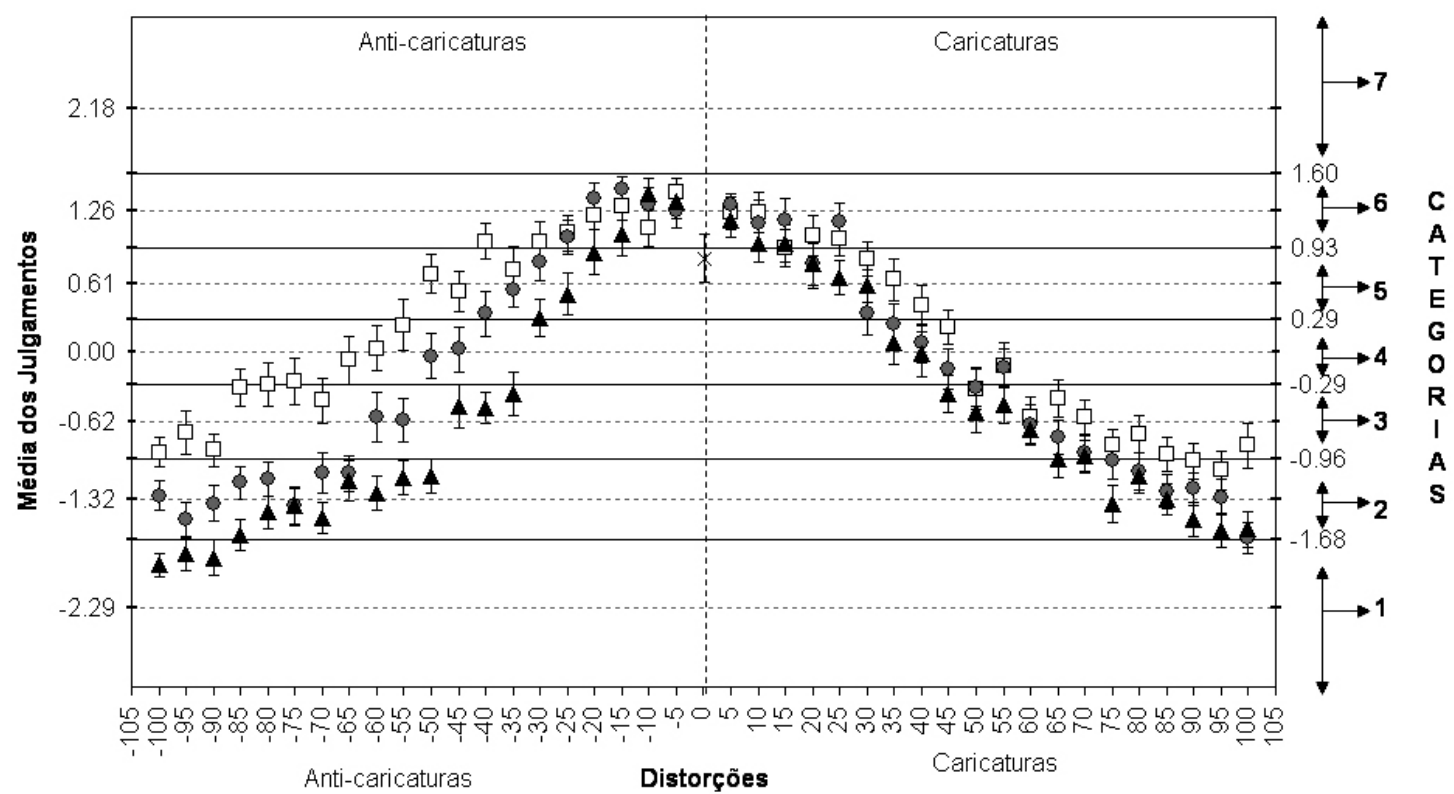

Face B

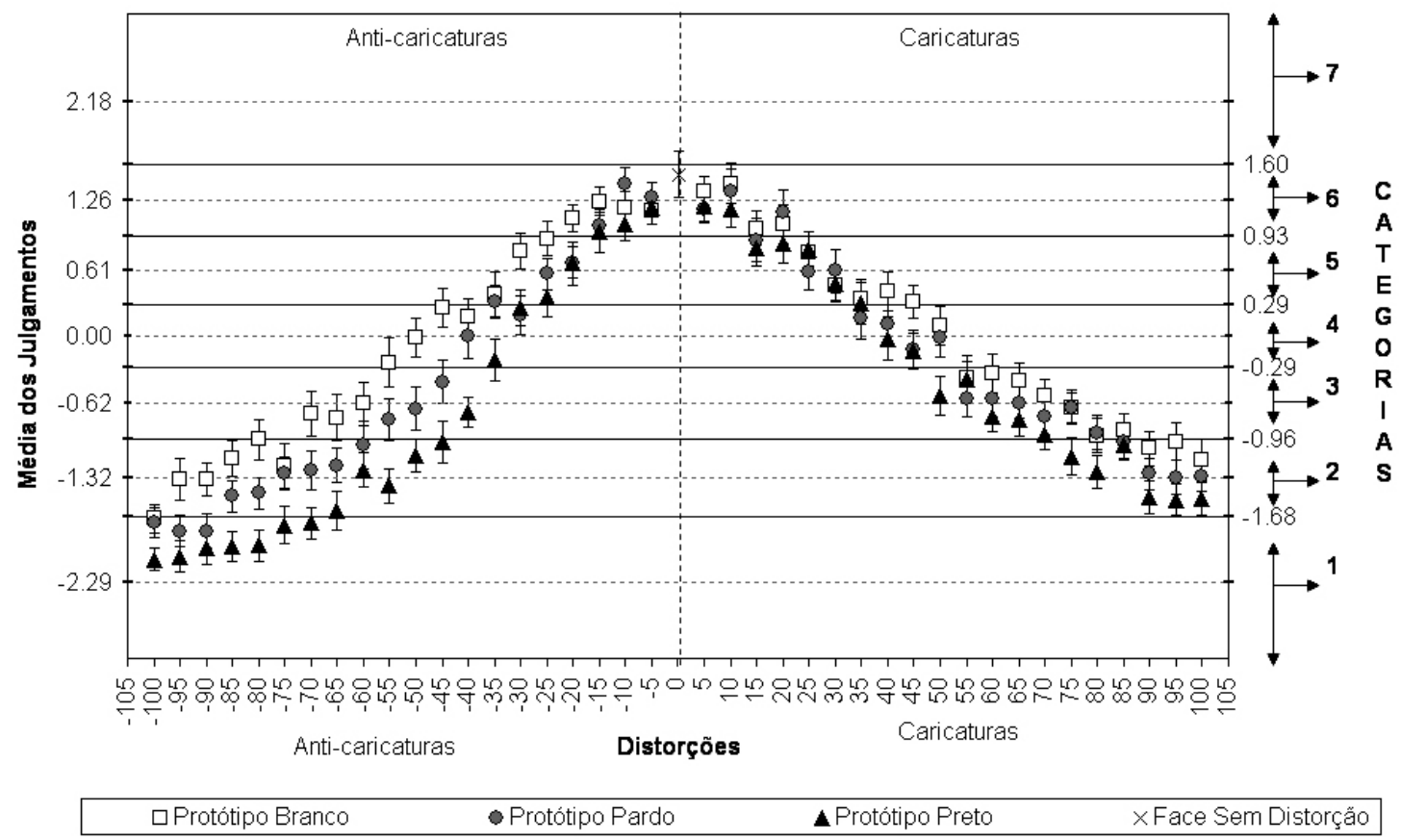

Figura 2.2.2 (A): Gráficos das médias dos julgamentos de similaridade com os respectivos errospadrão da média em função das distorções para as faces masculinas A e B. No eixo das ordenadas, à esquerda, encontram-se os pontos médios das categorias em nota $z$, à direita tem-se a extensão de cada categoria de julgamento. No eixo da abcissa têm-se as distorções das faces em relação aos protótipos. Quanto mais próximo a média de julgamento se encontra da categoria 7, maior a similaridade julgada entre a imagem distorcida e a face memorizada. 


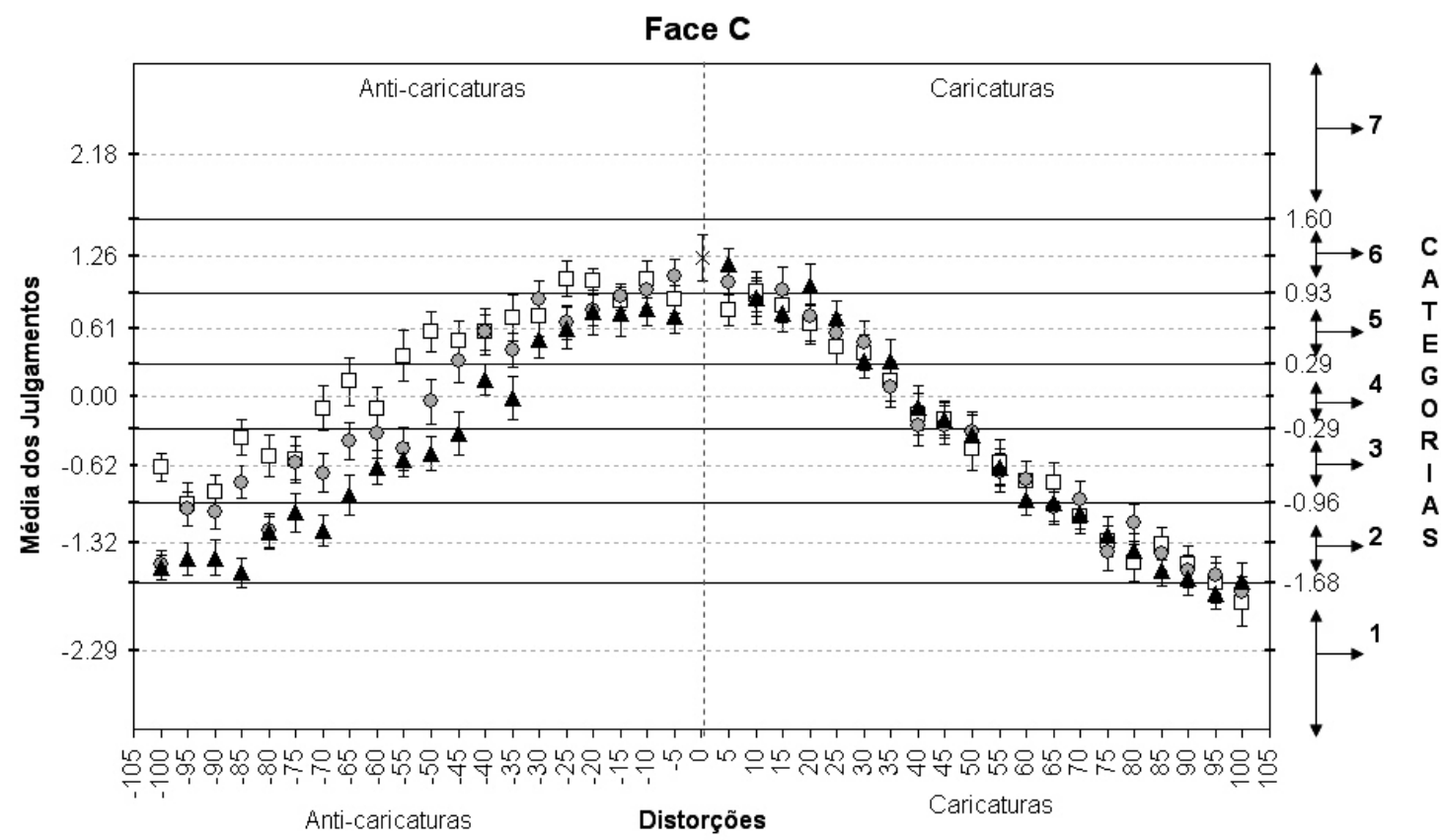

Face D

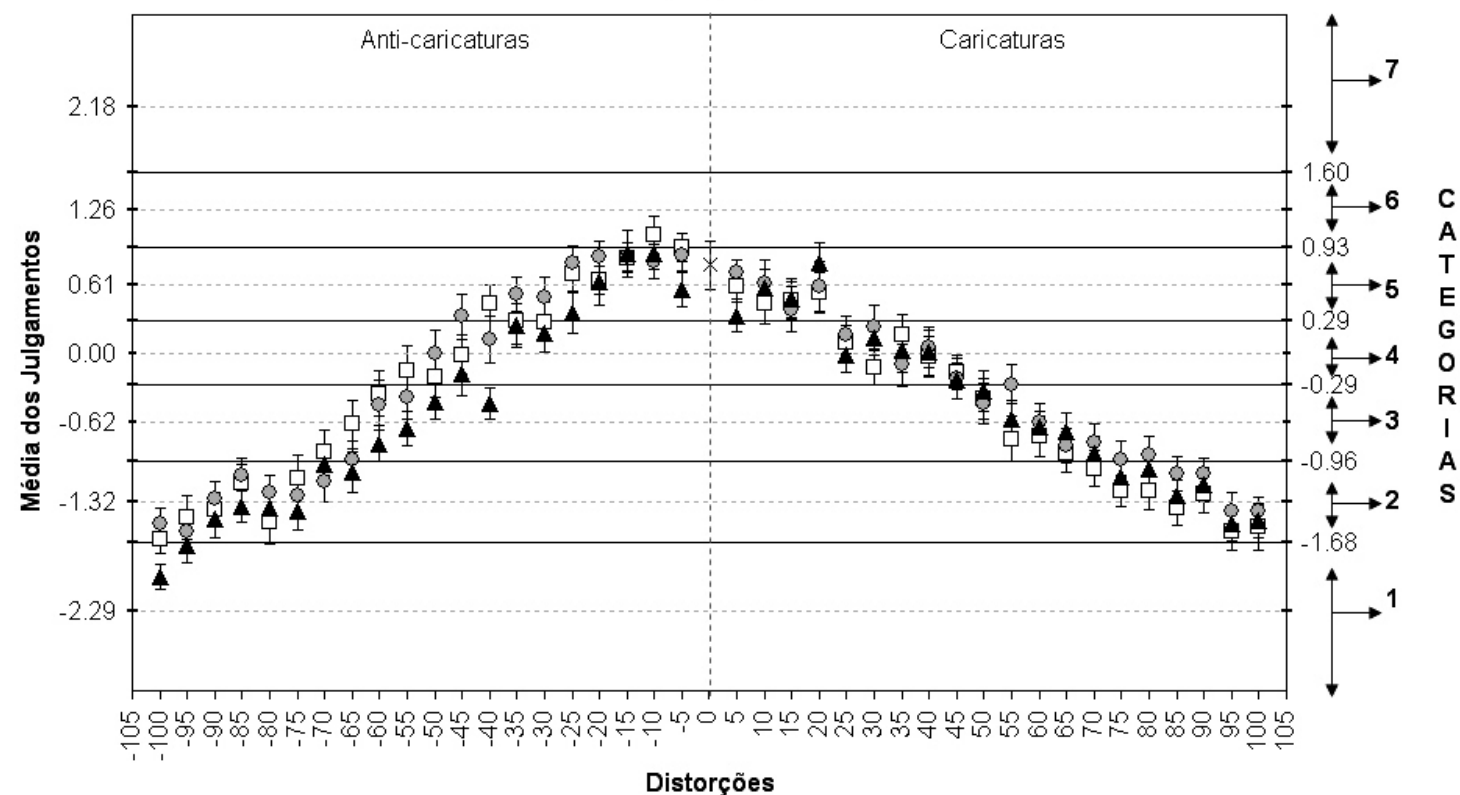

Figura 2.2.2 (B): Gráficos das médias dos julgamentos de similaridade com os respectivos errospadrão da média em função das distorções para as faces masculinas A e B. No eixo das ordenadas, à esquerda, encontram-se os pontos médios das categorias em nota $z$, à direita tem-se a extensão de cada categoria de julgamento. No eixo da abcissa têm-se as distorções das faces em relação aos protótipos. Quanto mais próximo a média de julgamento se encontra da categoria 7, maior a similaridade julgada entre a imagem distorcida e a face memorizada. 
Pode-se notar na Figura 2.2.2(A) e Figura 2.2.2.(B) que para as Faces A, B e C, as imagens distorcidas a partir do protótipo branco possuem tendência a serem ajustadas como mais similares a face memorizada do que as imagens distorcidas a partir do protótipo pardo e estas mais similares que as a partir das diferenças em relação ao protótipo preto. Para a Face D parece não haver diferença entre as distorções baseadas em cada um dos protótipos. Além disso, observa-se que a imagem com a maior média de julgamento de similaridade para as Faces B e C é a fotografia original da face. Entretanto, para a Face A a imagem julgada como mais similar a face memorizada é a anti-caricatura com grau de distorção de $-15 \%$ confeccionada a partir do protótipo pardo. E a anti-caricatura com grau de distorção $-10 \%$ derivada do protótipo branco foi a imagem julgada como mais similar a Face D.

Uma vez calculada a média e desvio padrão para cada uma das distorções, estimouse o d' (parâmetro de discriminação da Teoria da Detecção de Sinal) entre cada uma das distorções e a imagem original. Para isso, as recomendações de Macmillan e Creelman (1991) foram seguidas, e o critério ficou sob a distribuição da face original. O d'igual a 1 foi adotado como o critério a partir do qual as distribuições das imagens distorcidas são diferentes da distribuição da face original (limiar de dissimilaridade) e d'igual a 0 (zero) corresponde ao ponto de igualdade subjetiva (PIS) (Figura 2.2.3). O sinal de d' aponta a posição da distribuição da distorção em relação à distribuição da face original, sendo que sinal negativo para as caricaturas indica que ela está à esquerda da distribuição da face original e para a anti-caricaturas que está à direita da distribuição da face original. Em ambos os casos sinal negativo de $d^{\prime}$ indica que a imagem distorcida foi julgada como mais similar a face memorizada que a fotografia original da face. 

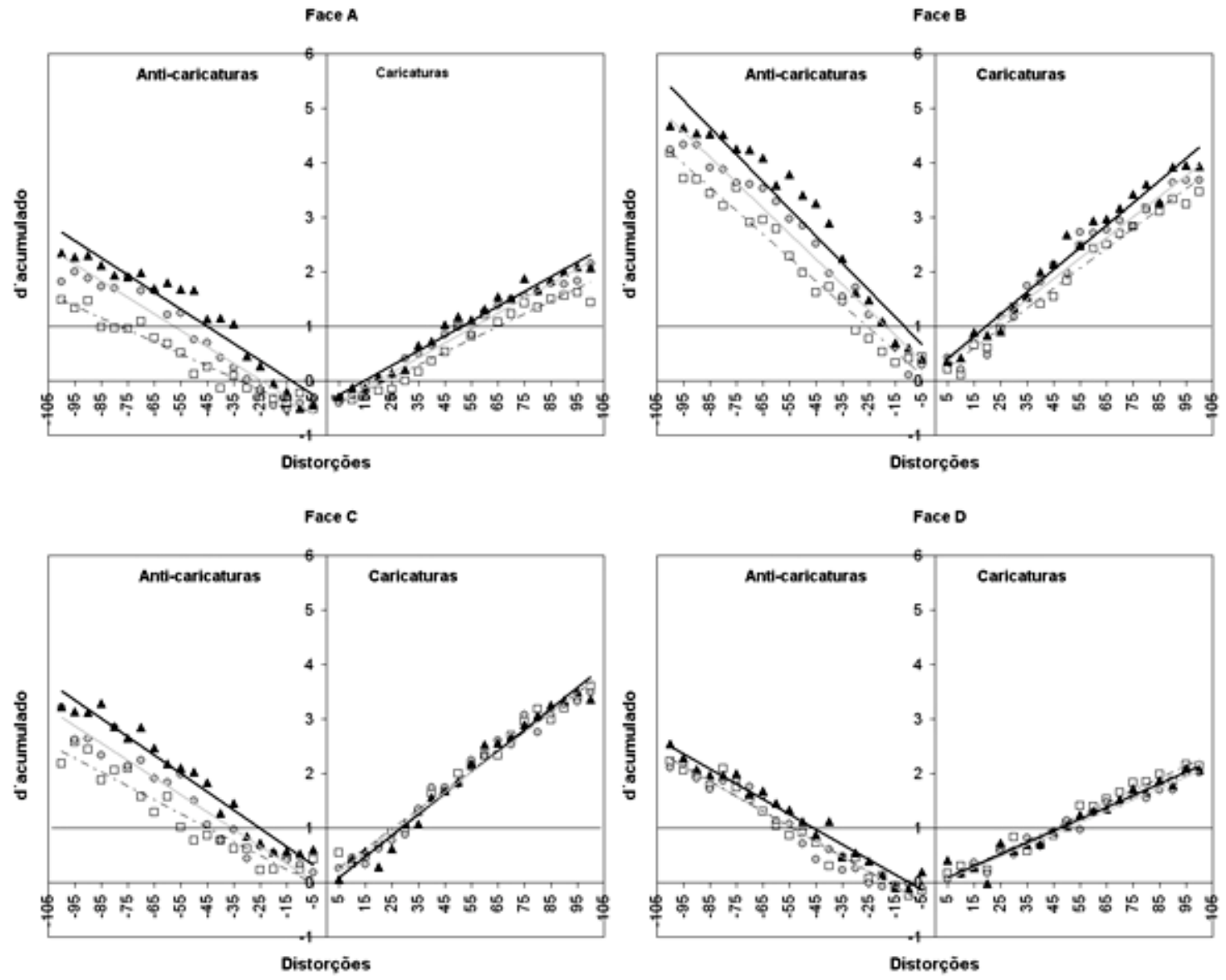

口 Protótipo Branco

- Prototipo Pardo

$\Delta$ Protótipo Preto

Figura 2.2.3: Para cada uma das quatro faces traçou-se o d' acumulado em função das distorções obtidas a partir de cada um dos protótipos das três cores. d'igual a 1 indica o limiar de dissimilaridade. $d^{\prime}$ igual a 0 corresponde ao ponto de igualdade subjetiva (PIS).

As equações das retas de regressão da Figura 2.2.3 em que $d^{\prime}$ acumulado $(f(x))$ foi traçado em função da distorção $(x)$ com os respectivos coeficientes de determinação $R^{2}$ encontram-se na Tabela 2.2.2. Nota-se que para todas as funções o coeficiente de determinação é maior que 0,90 indicando que a os dados podem ser representados por uma equação de regressão linear. Sendo assim, os PISs (valor da distorção quando $d^{\prime}=0$ ) foram estimados para cada uma das faces em todas as distorções utilizando-se a equação da reta e estão apresentados na Tabela 2.2.3 e representados na Figura 2.2.4. Nota-se nessa tabela e figura que os PISs são predominantemente negativos, concentrando-se nas anti-caricaturas. 
O limiar de dissimilaridade entre as faces distorcidas e a face original (critério $d^{\prime}=1$ ) foi estimado para cada face usando a equação da reta de regressão (Tabela 2.2.2) e estão representadas na Figura 2.2.5. Observando-se os limiares da Face A nota-se que o intervalo em que as imagens são julgadas iguais à face memorizada é maior quando as distorções da face são provenientes da comparação entre a face original e o protótipo de cor branca que quando o protótipo era de cor parda e esta última é maior que quando de cor preta. Nota-se ainda que a distorção a partir da qual há distinção entre a face distorcida e a face original é maior para as anti-caricaturas que para as caricaturas geradas a partir tanto do protótipo de cor branca quanto do de cor parda. Ainda para a Face A, pode-se observar que a distorção para as caricaturas confeccionadas a partir das diferenças entre a imagem original e o protótipo de cor preta é maior que as das anti-caricaturas geradas a partir do mesmo protótipo.

Diferentemente, quando se observa os resultados da Face B, ainda na Figura 2.2.5, nota-se que os limiares de dissimilaridade são maiores para as caricaturas independentemente do protótipo que as geraram. Também se pode notar que o intervalo entre os limiares de caricatura e anti-caricatura geradas está em ordem decrescente, sendo maior para as imagens distorcidas a partir do protótipo de cor branca e menor para as geradas a partir do protótipo de cor preta. Comparando-se as quatro faces, a Face B é a que possui menor intervalo entre os limiares de dissimilaridade.

Para a Face C (Figura 2.2.5), o limiar de dissimilaridade entre faces distorcidas e face original é maior para anti-caricaturas quando essas foram geradas a partir dos protótipos de cor branca e parda. O intervalo entre os limiares da dissimilaridade é maior quando esses são derivados das comparações entre a face original e as distorções produzidas a partir do protótipo branco.

O maior limiar de dissimilaridade da Face D é para a anti-caricatura derivada do protótipo branco. Os limiares de dissimilaridade para as caricaturas são maiores que para as anti-caricaturas quando essas distorções são derivadas dos protótipos de cores parda e preta. O intervalo em que não há diferenciação entre os estímulos julgados é maior quando estes foram produzidos a partir da comparação com o protótipo branco. 
Tabela 2.2.2: Equações das retas de regressão e respectivos $R^{2}$ para cada uma das faces em função dos protótipos das três cores.

\begin{tabular}{|c|c|c|c|c|c|c|}
\hline & & & Face A & Face B & Face C & Face D \\
\hline \multirow{2}{*}{ 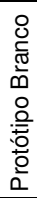 } & Caricatura & $\begin{array}{c}\text { Equação da reta de } \\
\text { regressão } \\
\mathrm{R}^{2}\end{array}$ & $\begin{array}{c}f(x)=0,0235 x-0,5241 \\
R^{2}=0,9405\end{array}$ & $\begin{array}{c}f(x)=0,0365 x+0,0553 \\
R^{2}=0,973\end{array}$ & $\begin{array}{c}f(x)=0,0358 x+0,0883 \\
R^{2}=0,984\end{array}$ & $\begin{array}{c}f(x)=0,0228 x-0,0183 \\
R^{2}=0,9665\end{array}$ \\
\hline & Anti-caricatura & $\begin{array}{c}\text { Equação da reta de } \\
\text { regressão } \\
\mathrm{R}^{2}\end{array}$ & $\begin{array}{c}f(x)=-0,0219 x-0,710 \\
R^{2}=0,9516\end{array}$ & $\begin{array}{c}f(x)=-0,043 x-0,1121 \\
R 2=0,9738\end{array}$ & $\begin{array}{c}f(x)=-0,0255 x-0,1441 \\
R^{2}=0,9115\end{array}$ & 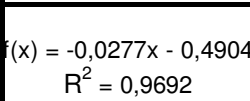 \\
\hline \multirow{2}{*}{$\begin{array}{l}\text { 음 } \\
\frac{0}{0} \\
\text { 을 } \\
\text { 을 } \\
\text { 뭉 }\end{array}$} & Caricatura & $\begin{array}{c}\text { Equação da reta de } \\
\text { regressão } \\
\mathrm{R}^{2}\end{array}$ & $\begin{array}{c}f(x)=0,0272 x-0,5339 \\
R^{2}=0,9648\end{array}$ & $\begin{array}{c}f(x)=0,0378 x+0,1787 \\
R^{2}=0,9602\end{array}$ & $\begin{array}{c}f(x)=0,0364 x+0,0178 \\
R^{2}=0,9762\end{array}$ & $\begin{array}{c}f(x)=0,0209 x-0,0424 \\
R^{2}=0,9735\end{array}$ \\
\hline & Anti-caricatura & $\begin{array}{c}\text { Equação da reta de } \\
\text { regressão } \\
R^{2}\end{array}$ & 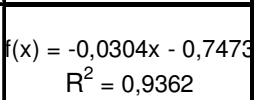 & $\begin{array}{c}f(x)=-0,0467 x+0,1278 \\
R^{2}=0,963\end{array}$ & $\begin{array}{c}f(x)=-0,0316 x-0,1242 \\
R^{2}=0,9473\end{array}$ & 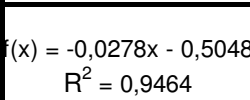 \\
\hline \multirow{2}{*}{ 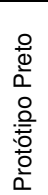 } & Caricatura & $\begin{array}{c}\text { Equação da reta de } \\
\text { regressão } \\
\mathrm{R}^{2}\end{array}$ & $\begin{array}{c}f(x)=0,0272 x-0,399 \\
R^{2}=0,9704\end{array}$ & $\begin{array}{c}f(x)=0,0408 x+0,1984 \\
R^{2}=0,9694\end{array}$ & $\begin{array}{c}f(x)=0,0387 x-0,1037 \\
R^{2}=0,9759\end{array}$ & $\begin{array}{c}f(x)=0,0215 x-0,0144 \\
R^{2}=0,949\end{array}$ \\
\hline & Anti-caricatura & $\begin{array}{c}\text { Equação da reta de } \\
\text { regressão } \\
\mathrm{R}^{2}\end{array}$ & $\begin{array}{c}f(x)=-0,0313 x-0,414 \\
R^{2}=0,9208\end{array}$ & 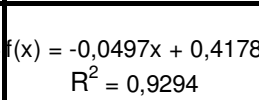 & 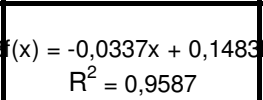 & $\begin{array}{c}(x)=-0,0277 x-0,2755 \\
R^{2}=0,9658\end{array}$ \\
\hline
\end{tabular}

Tabela 2.2.3: Pontos de Igualdade Subjetiva (PIS) expresso em porcentagem de distorção sendo que sinal positivo indica caricatura, sinal negativo (-) indica anti-caturatura. O PIS foi calculado para as caricaturas e anti-caricaturas obtidas a partir da comparação com os protótipos das três cores/raças de cada uma das faces. O PIS foi estimado através equação da reta de regressão, sendo equivalente a $\mathrm{d}^{\prime}=0$.

\begin{tabular}{cc|cccc}
\hline & & Face A & Face B & Face C & Face D \\
\hline Protótipo & Caricatura & 22,787 & $-1,515$ & $-2,466$ & 0,803 \\
Branco & Anti-caricatura & $-32,457$ & $-2,607$ & $-5,651$ & $-17,704$ \\
\hline Protótipo & Caricatura & 19,629 & $-4,728$ & $-0,489$ & 2,029 \\
Pardo & Anti-caricatura & $-24,582$ & 2,737 & $-3,930$ & $-1,816$ \\
\hline Protótipo & Caricatura & 14,669 & $-4,863$ & 2,680 & 0,670 \\
Preto & Anti-caricatura & $-13,227$ & 8,406 & 4,401 & $-9,946$ \\
\hline
\end{tabular}




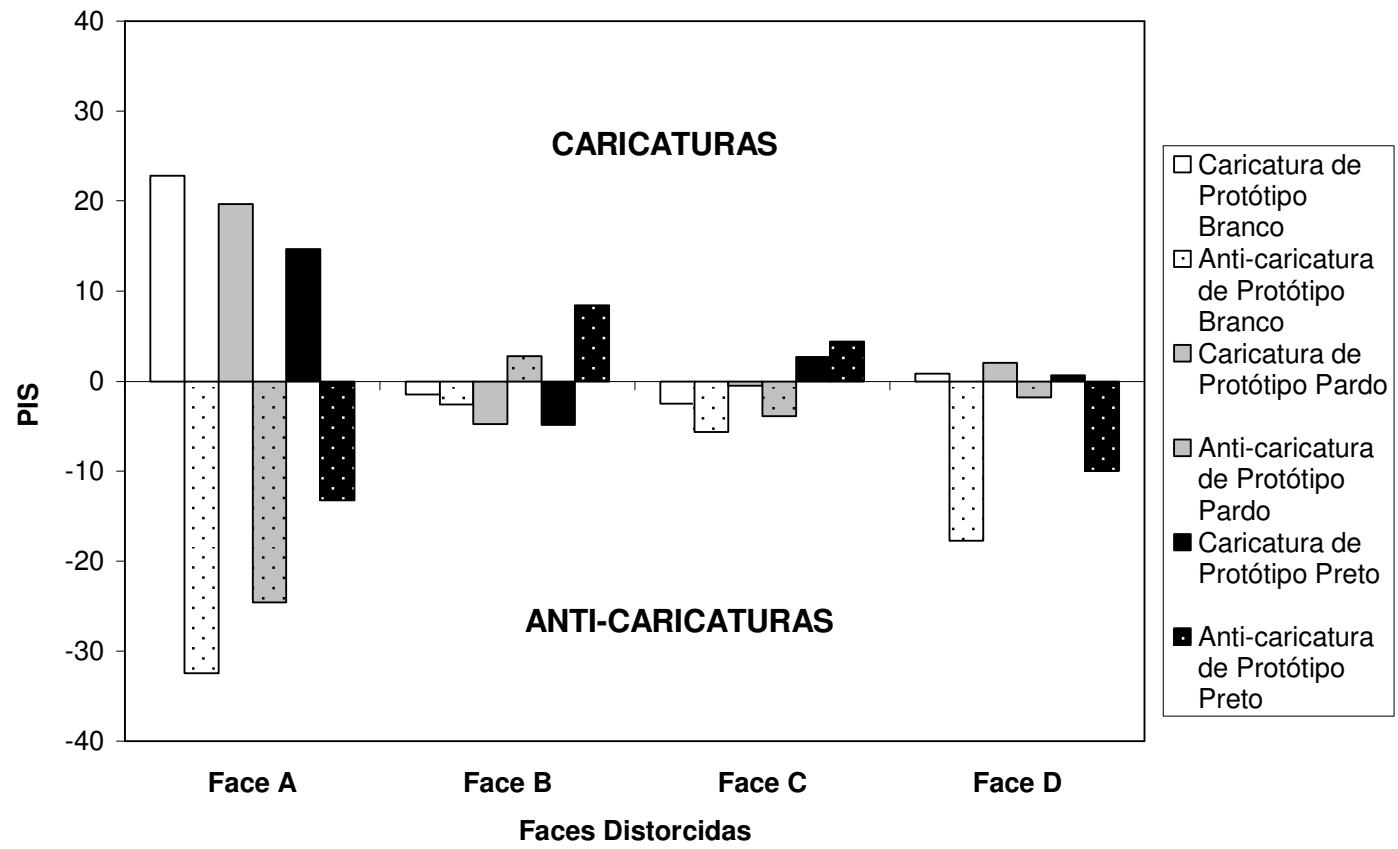

Figura 2.2.4: Representação gráfica dos PIS (medido em porcentagem de distorção) para as caricaturas e anti-caricaturas derivadas dos protótipos das três cores/raças de cada uma das faces.

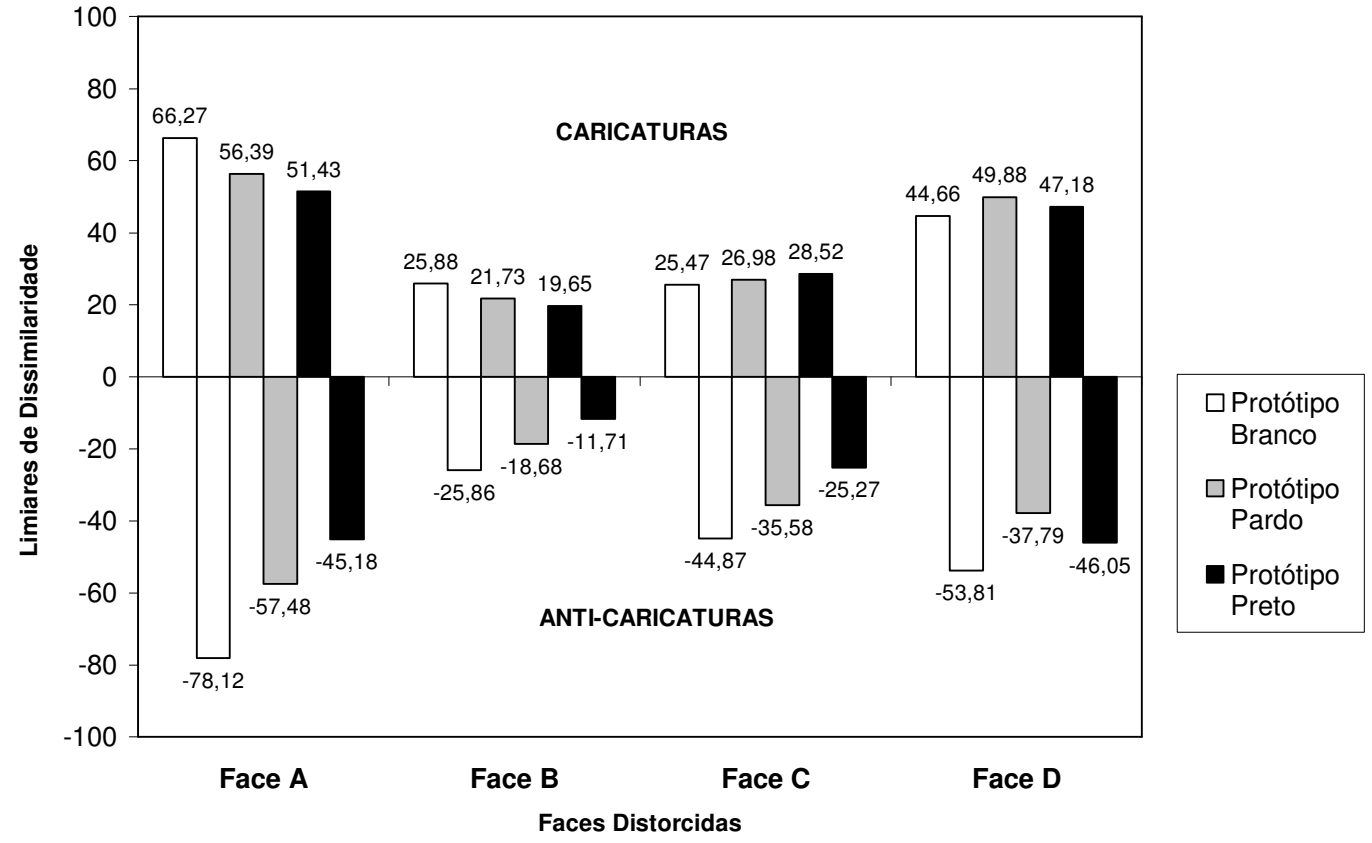

Figura 2.2.5: Graus de distorção quando d' igual a 1 (em porcentagem de distorção) para as caricaturas e anti-caricaturas geradas a partir da diferença em relação aos protótipos faciais das três cores em função de cada face. Acima do eixo das abcissas têm-se as distorções para as caricaturas, abaixo para as anti-caricaturas. Quanto maior o limiar de dissimilaridade, maior a dificuldade de discriminação entre a imagem distorcida e a fotografia original. 


\subsubsection{Tempo de Reação}

Para cada uma das quatro faces foi estimada a média do tempo de reação dos participantes nas anti-caricaturas e caricaturas geradas a partir de cada um dos três protótipos (Figura 2.2.6). Essas médias dos tempos de reação foram submetidas ao teste de normalidade Shapiro-Wilk e obteve-se que as distribuições dos tempos de reação de todas as faces tendem a normal $(p>0,01)$. Feito isto, uma ANOVA para medidas repetidas ( 4 faces $x 2$ tipos de distorção x 3 protótipos) foi aplicada aos resultados. Segundo o teste estatístico utilizado, há diferença significativa entre as médias dos tempos de reação das quatro faces $(\underline{F}(3,87)=3,368 ; \underline{p}<0,05)$, entre as médias dos tempos de reação das anti-caricaturas e caricaturas $(\underline{F}(1,29)=7,782 ; p<0,01)$ e entre as médias dos tempos de reação dos três protótipos faciais $(\underline{F}(2,58)=3,408 ; \underline{p}<0,05)$. O teste não indicou efeito significativo da interação dos fatores $(p>0,05)$. Observando a Figura 2.2.6 pode-se notar os tempos de reação para as Faces $B$ e $D$ tendem a serem menores que os tempos de reação que as Faces $A$ e $C$, independente do protótipo em que as distorções foram baseadas. O menor tempo de reação das Faces A e B são para as caricaturas construídas a partir do protótipo de cor parda, já para as Faces $\mathrm{C}$ e $\mathrm{D}$ o menor tempo de reação tende a ser para as caricaturas geradas a partir do protótipo de cor branca. Numa observação mais ampla, pode-se afirmar que o tempo de reação médio para as caricaturas é menor que para as anti-caricaturas, o tempo de reação médio é menor para a Face B e o menor tempo de reação médio é para as distorções construídas a partir do protótipo pardo, seguido pelas geradas a partir do protótipo branco. 


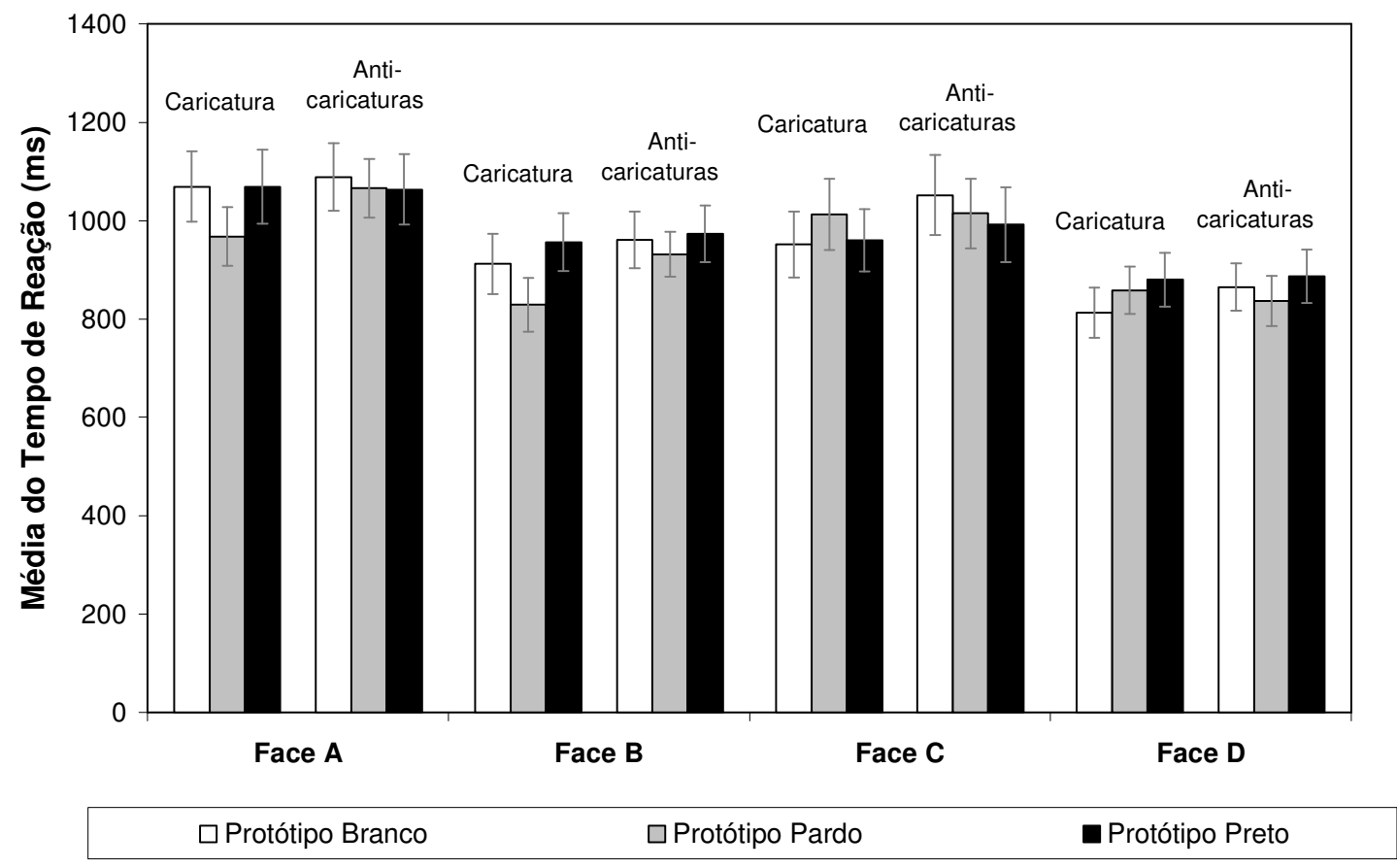

Figura 2.2.6: Gráfico de colunas das médias do tempo de reação (em milisegundos) com os respectivos erros padrão da média, das anti-caricaturas e caricaturas geradas a partir dos três protótipos faciais em função das quatro faces.

\subsubsection{Discussão}

Conforme os objetivos originais desta pesquisa, este experimento forneceu resultados que permitiram investigar o grau de exagero das características peculiares de uma face que garante que a imagem caricaturada seja julgada como mais similar à face memorizada que a fotografia sem distorção da face. Os resultados revelam não haver vantagem da caricatura holísticas com qualidade fotográfica sobre a fotografia original da face na tarefa de julgamento de similaridade. Portanto, não foi encontrado um grau ótimo de distorção para que a caricatura seja a melhor representação da face memorizada.

A observação que induz a esta afirmação está exposta na Figura 2.2.2 a e b em que se traçou as médias dos julgamentos de similaridade em função da distorção. Nesta figura nota-se que as imagens com maior média de similaridade com a face memorizada são as fotografias originais da face (Faces B e C) ou anti-caricaturas (Faces A e D). Portanto, os 
resultados indicam que a caricatura com imagem fotográfica não pode ser considerada um super-retrato.

Em alguns casos as caricaturas são tão representativas da face memorizada quanto a fotografia original, o que se pode deduzir observando os limiares de dissimilaridade. $\mathrm{Na}$ Figura 2.2.5, nota-se que as caricaturas da Face B tendem a ser julgadas como mais parecidas com a face memorizada que suas anti-caricaturas.

Uma outra questão que permeou os objetivos iniciais da pesquisa foi se há diferença entre julgamentos de similaridade quando as distorções das imagens são determinadas a partir da comparação com cada um dos três protótipos derivados de amostras da população brasileira. Os resultados experimentais evidenciam que sim. Também na Figura 2.2.5, observa-se que os limiares de dissimilaridade diferem de acordo com protótipo utilizado para gerar as distorções. Quando os exageros são oriundos da comparação entre faces brancas e o protótipo de cor de preta, os limiares de dissimilaridade são maiores para as caricaturas que para as anti-caricaturas. Nesse caso, as caricaturas devem ser representações melhores que as anti-caricaturas porque essas últimas reduzem as informações sobre a cor/raça da face que deve ser importante para o julgamento de similaridade.

No que diz respeito à área da diferença entre cada uma das faces e os protótipos, tem-se que as Faces $A, B$ e $C$ possuem suas menores áreas em relação ao protótipo branco. Por outro lado, para a Face D possui sua a menor área da diferença quando esta fora comparada ao protótipo de cor parda. Se o modelo do espaço multidimensional proposto por Valentine (1991) estiver correto, a diferença entre uma face e o protótipo indica sua tipicidade, sendo que faces mais próximas ao protótipo são mais típicas e faces mais distantes são mais atípicas. Sendo assim, pode-se inferir que as formas das Faces A, B e C estão mais próximas à forma da categoria da cor branca, enquanto a forma da Face $D$ está mais próxima à forma da categoria da cor parda. Somando-se a isso, pode-se deduzir que a Face B é a mais peculiar entre as quatro faces, uma vez que esta possui a maior diferença de área em relação ao protótipo branco. 
Os resultados da análise do tempo de reação também favorecem a afirmação que a Face B é a mais típica entre as quatro faces analisadas. Experimentos de categorização de faces (Valentine \& Bruce, 1986) evidenciam que faces mais peculiares são categorizadas mais rapidamente que faces típicas. Dentre as quatro faces, a Face $B$, a que possui menor área da diferença em relação o protótipo é a que possui menor tempo de reação. Desta forma, pode-se inferir que a área da diferença em relação ao protótipo é adequada para estimar a peculiaridade da face.

Dentre as quatro fotografias de faces manipuladas, a Face $B$, provavelmente a mais típica entre as quatro, foi a única cujas caricaturas (independente do protótipo que as geraram) possuem uma tendência maior que as anti-caricaturas de serem julgadas como tão parecidas à face memorizada quanto a face original. Diferentemente, as anti-caricaturas geradas para as Faces A, C e D apresentam tendência de serem julgadas como tão parecidas com a face memorizada quanto a fotografia original da face. A partir desses resultados, levanta-se a hipótese de que, para que a caricatura seja tão representativa de uma face quanto sua fotografia original é necessária uma diferença mínima entre a face e o protótipo. Faces muito típicas, por estarem numa área de densidade muito alta no espaço multidimensional estariam muito próximas ao protótipo, agregando alto erro de julgamento e sendo facilmente confundidas.

Quando se analisa a área da diferença entre a face original e cada um dos protótipos (Tabela 2.2.1) junto com o limiar de dissimilaridade (Figura 2.2.5), encontra-se uma tendência a diminuir o limiar de dissimilaridade com o aumento da área da diferença entre as duas imagens. Esse resultado pode indicar uma interação entre cor/raça e caricatura, como previsto no modelo do espaço multidimensional (Valentine, 1991). Sendo assim, quanto maior a diferença entre as cores/raças da face original e do protótipo utilizado para produzir a caricaturas e anti-caricaturas menor será a similaridade entre as caricaturas e anti-caricaturas e a face original.

Contrapondo essa questão, os resultados dos experimentos de Chiroro e Valentine (1995) sugerem que o contato com faces de outras etnias mudaria o protótipo facial do es- 
paço multidimensional. Sendo assim, numa situação como a brasileira de diversidade cultural e miscigenação, pode-se supor que as anti-caricaturas foram mais eficazes que as caricaturas quando comparadas ao protótipo branco porque este não seria o mais adequado para determinar o que é memorizado na face.

Analisando-se o tempo de reação, tem-se que as respostas para as caricaturas foram mais rápidas que para as anti-caricaturas, o que favorece o modelo do espaço multidimensional que prediz que aumentando-se a peculiaridade da face diminui-se o tempo de reação. E como não houve vantagem da caricatura sobre a face original, essa diminuição do tempo de reação das caricaturas deve ser porque essas facilitam a associação entre a face julgada e a face memorizada.

Os resultados também apontam que o tempo de reação foi menor quando as distorções das imagens julgadas foram derivadas da comparação entre cada face e o protótipo de cor parda. Apoiando-se nesses resultados, pergunta-se a desvantagem da caricatura sobre a face original se deu porque não se utilizou um protótipo adequado para produzir as distorções. Segundo a hipótese do modelo do espaço multidimensional baseado na norma, o protótipo para a população brasileira uma figura formada pela fusão de faces brancas, pretas e pardas. Tomando-se os resultados para o tempo de reação, pode-se dizer que o protótipo de cor parda seria o mais adequado, entre os três utilizados, para caracterizar o protótipo que se forma a partir da população brasileira, o que demanda maiores investigações. 


\subsection{Experimento II}

O Experimento II foi elaborado para investigar a hipótese da peculiaridade através do modelo de processamento de elementos isolados da face. Para isso, utilizaram-se caricaturas e anti-caricaturas em que os elementos faciais internos e suas combinações foram modificados.

\subsubsection{Método}

\subsubsection{Participantes}

Outras trinta pessoas, sendo 11 homens e 19 mulheres, com idade entre 20 e 45 anos (idade média igual a 24,5 e desvio-padrão igual a 5,6 anos), brasileiras e ingênuas quanto ao objetivo do experimento, participaram do Experimento II em caráter voluntário. Destes 30 participantes, 21 se auto-declararam brancos, 04 pardos e 05 amarelos. Antes do início da sessão experimental, os participantes leram e assinaram o termo de consentimento livre e esclarecido (Apêndice D) conforme aprovação do Comitê de Ética em Pesquisa da $\operatorname{FFCLRP~(Anexo~A).~}$

\subsubsection{Materiais e Aparatos}

Os mesmos microcomputador Pentium IV ${ }^{\circledR}$ e monitor de 19" utilizados no Experimento I foram utilizados para editar as imagens e apresentar os estímulos do Experimento II.

O programa computacional utilizado na apresentação dos estímulos e coleta de dados foi SuperLab Pro ${ }^{\circledR}$ versão 2.0.4 da Cedrus $^{\circledR}$ (http://www.cedrus.com).

Utilizaram-se os mesmos quatro filmes de um minuto e meio dos apresentadores do telejornal local utilizado no Experimento I cujas apresentações foram feitas no Windows Media Player ${ }^{\circledR}$.

Foram utilizadas as mesmas quatro fotografias frontais da face dos jornalistas usadas no Experimento I. Ao invés de se confeccionar caricaturas e anti-caricaturas holísticas 
das faces, como no experimento anterior, geraram-se imagens de 600x434 pixels (resolução de 72 dpi) em que elementos faciais isolados, ou a combinação destes foram distorcidos (para maiores informações de como essas imagens foram geradas consulte o Apêndice B). Foram geradas imagens em que apenas os olhos ou nariz ou boca ou a combinação destes elementos (olhos-nariz, olhos-boca, nariz-boca e olhos-nariz-boca) sofreram distorções. As distorções das anti-caricaturas e caricaturas variaram entre $-100 \%$ e $+100 \%$, com intervalos de $10 \%$.

\subsubsection{Procedimento}

Após concordar com os termos do experimento e declarar sua cor/ raça segundo as categorias do IBGE, os participantes foram submetidos à sessão experimental dividida em quatro blocos, um para cada face de apresentador no telejornal local, de até 10 minutos cada. Eles fizeram o experimento em situação binocular, sentados a $50 \mathrm{~cm}$ da tela do monitor. Cada bloco consistia em duas tarefas: a memorização de uma face e em seguida o julgamento da similaridade entre a face memorizada e o estímulo apresentado. Os blocos foram feitos em ordem aleatória.

Memorização da face: Assim como no experimento anterior, o participante deveria dizer se conhecia o apresentador cuja face seria memorizada. Em seguida, o participante assistiu ao filme de um minuto e meio e sua tarefa foi memorizar a face prestando atenção aos elementos internos da face. A tarefa de memorização foi feita numa sala iluminada, com a presença do experimentador.

Julgamento de similaridade: Do mesmo modo que no Experimento I, após a tarefa de memorização, o participante fez o julgamento de similaridade entre a face memorizada e cada uma das caricaturas e anti-caricaturas. Os sujeitos do experimento foram informados que the seriam apresentadas imagens distorcidas e não distorcidas da face memorizada e que sua tarefa era dizer o quanto cada estímulo se parecia com esta. O julgamento deveria ser expresso em números inteiros de 1 a 7 , sendo que o valor 1 indicava que o estímulo apresentado não se parecia em nada com a face memorizada e o valor 7 indicava que era i- 
dêntica. Dadas as instruções, a luz da sala foi apagada e os 141 estímulos foram apresentadas em fundo preto e em ordem aleatória na tela do monitor. Cada estímulo foi apresentado por um segundo e meio, em seguida, com tempo de exposição livre, o participante deveria digitar sua resposta utilizando o teclado numérico do computador. Entre a resposta e o próximo estímulo foi apresentado uma tela por 500 ms. No final de cada bloco o participante poderia fazer uma pausa. Cada participante fez a memorização e julgamentos de similaridade das faces dos quatro apresentadores.

\subsubsection{Resultados}

Dentre os 30 participantes, 24 declararam conhecer a Face A antes da tarefa de memorização, 26 declararam conhecer a Face B, 21 conheciam a Face $\mathrm{C}$ de antes do experimento e 18 conheciam a Face D. Do mesmo modo que para o Experimento I, as diferenças que cada face tem em relação aos três protótipos da população brasileira, os julgamentos de similaridade e o tempo que o participante levou para emitir sua resposta (tempo de reação) foram analisados e se encontram detalhados a seguir.

\subsubsection{Diferença entre os elementos faciais e os protótipos}

As áreas da diferença entre cada elemento facial das quatro faces em relação ao protótipo branco foram calculadas a partir da sobreposição dos traços que definem os elementos faciais e podem ser observadas em forma de desenho na Figura 2.3.1 e estão expressas numericamente na Tabela 2.3.1. Quanto maior a área da diferença, maior a peculiaridade do elemento facial. Dentre as faces, a que possui a boca mais peculiar foi a Face A, o nariz mais peculiar pertence a Face $D$ e a face que possui a região dos olhos como a mais peculiar é a Face B. 


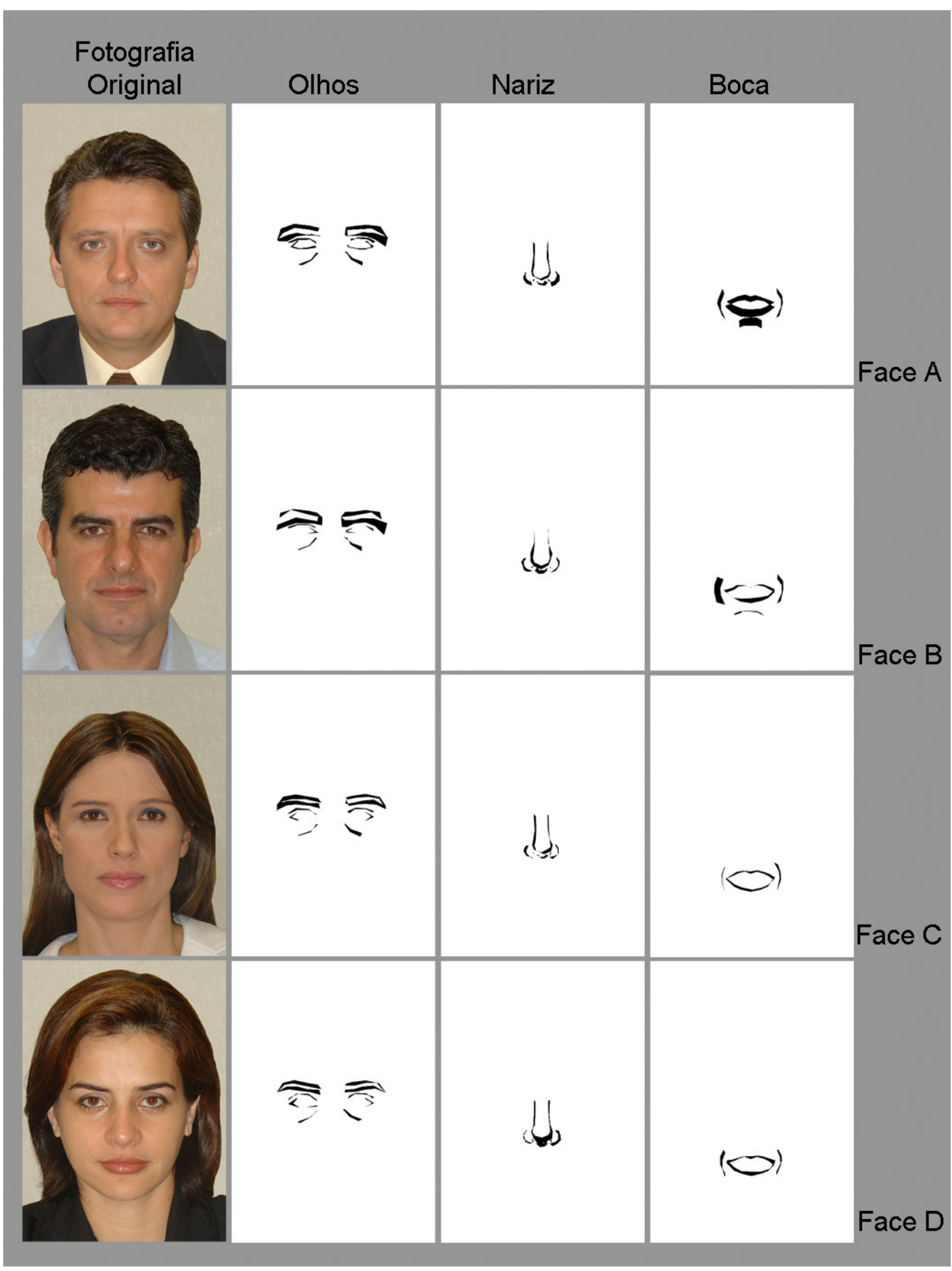

Figura 2.3.1: Em preto têm-se a área da diferença entre os elementos faciais de cada uma das faces. Essas diferenças são em relação aos mesmos elementos do protótipo de cor branca. As imagens originais têm 434 × 600 pixels de tamanho e resolução de 72 dpi. 
Tabela 2.3.1: Área da diferença em $\mathrm{mm}^{2}$ entre cada um dos elementos faciais e o protótipo branco. As imagens originais têm $434 \times 600$ pixels de tamanho e resolução de 72 dpi.

\begin{tabular}{cccc}
\hline & Olhos & Nariz & Boca \\
\hline Face A & 508.90 & 143.90 & 480.40 \\
Face B & 541.00 & 153.30 & 282.60 \\
Face C & 440.90 & 134.20 & 136.60 \\
Face D & 369.70 & 176.90 & 179.90 \\
\hline
\end{tabular}

\subsubsection{Julgamento de similaridade}

Assim como no Experimento I, os dados aqui gerados são qualitativos no nível ordinal e também foram convertidos para escala intervalar seguindo o procedimento indicado por Guilford (1954). Sendo assim, para cada face, foram estimadas a extensão das categorias de julgamento em nota $z$ e as médias com os respectivos desvios-padrão para as distorções de cada um dos elementos faciais e suas combinações. Essas médias, com os respectivos erros-padrão da média foram traçados em função da distorção para cada uma das quatro imagens (Figura 2.3.2 (A), (B), (C) e (D)). Nota-se na Figura 2.3.2 (A) que a imagem com maior média de julgamento de similaridade para a Face A foi a anti-caricatura de nariz com $-20 \%$ de distorção. Na Figura 2.3.2 (B) observa-se que a caricatura de olhos com distorção de $+10 \%$, foi a imagem com maior julgamento de similaridade para a Face $\mathrm{B}$. Na Figura 2.3.2 (C) nota-se que a caricatura de boca com distorção de $+20 \%$ é a imagem com maior índice de similaridade para a Face C. E para a Face D, a anti-caricatura da combinação olhos e nariz com distorção de $-10 \%$ foi a imagem julgada como mais similar a face memorizada (Fig. 2.3.2 (D)). 
Face A

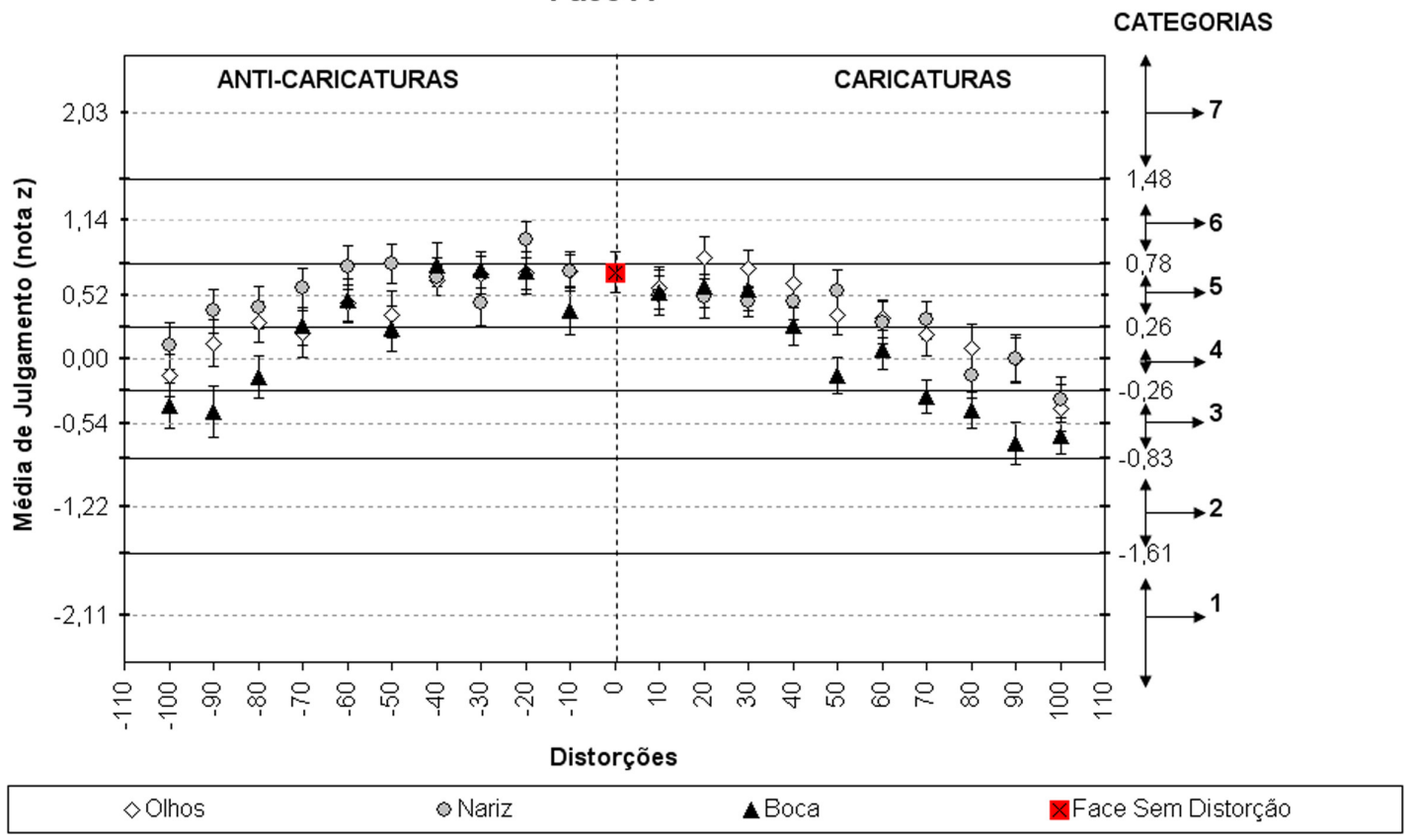

Face A

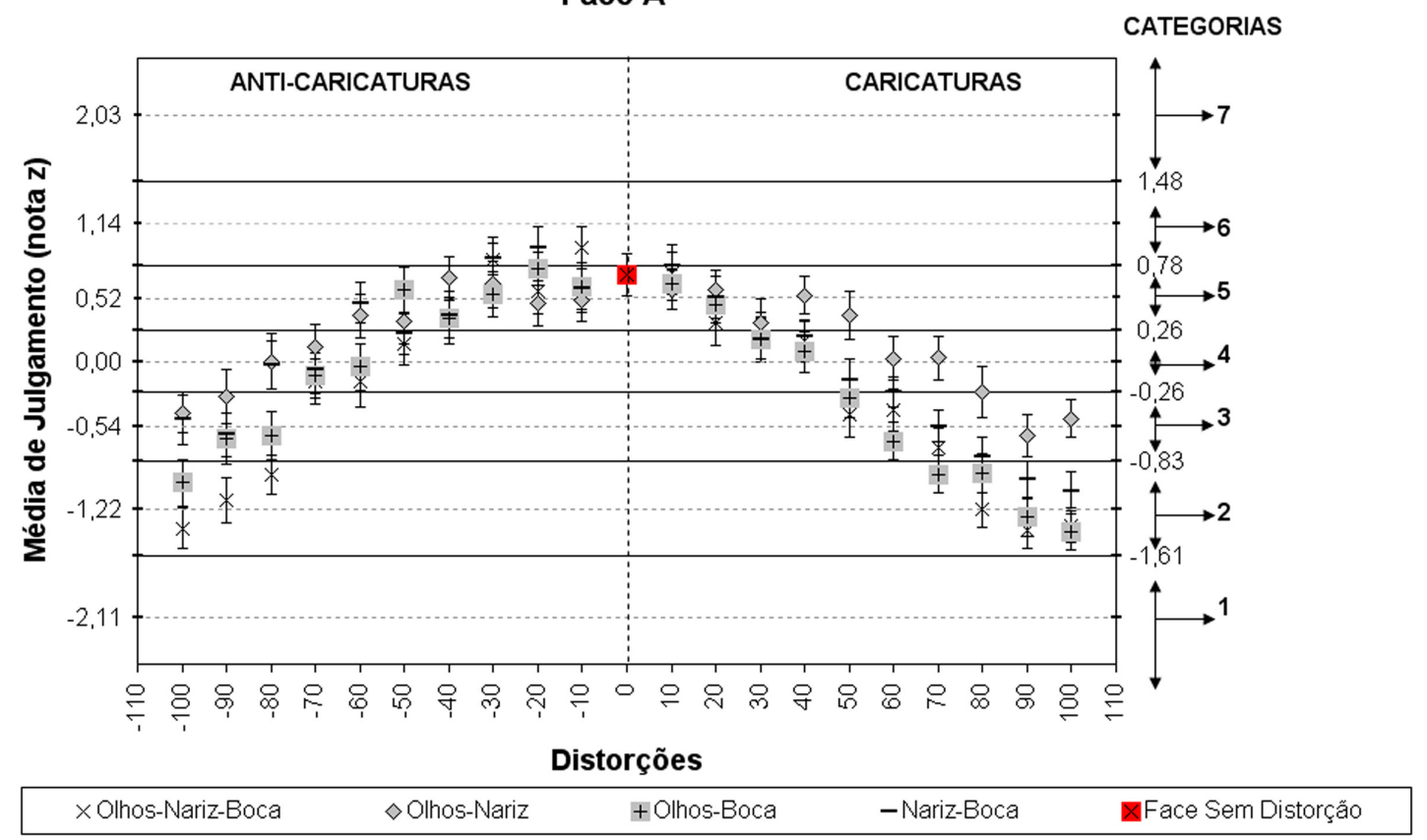

Figura 2.3.2 (A): Gráficos das médias dos julgamentos com os respectivos erros-padrão da média em função das distorções para a Face A. Acima têm-se o gráfico das distorções para elementos faciais isolados, abaixo têm-se o gráfico para as distorções dos elementos faciais combinados. No eixo das ordenadas, à esquerda, encontram-se os pontos médios das categorias em nota $z$, à direita temse a extensão de cada categoria de julgamento. No eixo da abcissa têm-se dos elementos faciais em relação ao protótipo de cor branca. Quanto mais próximo a média de julgamento se encontra da categoria 7, maior a similaridade julgada entre a imagem distorcida e a face memorizada. 


\section{Face B}

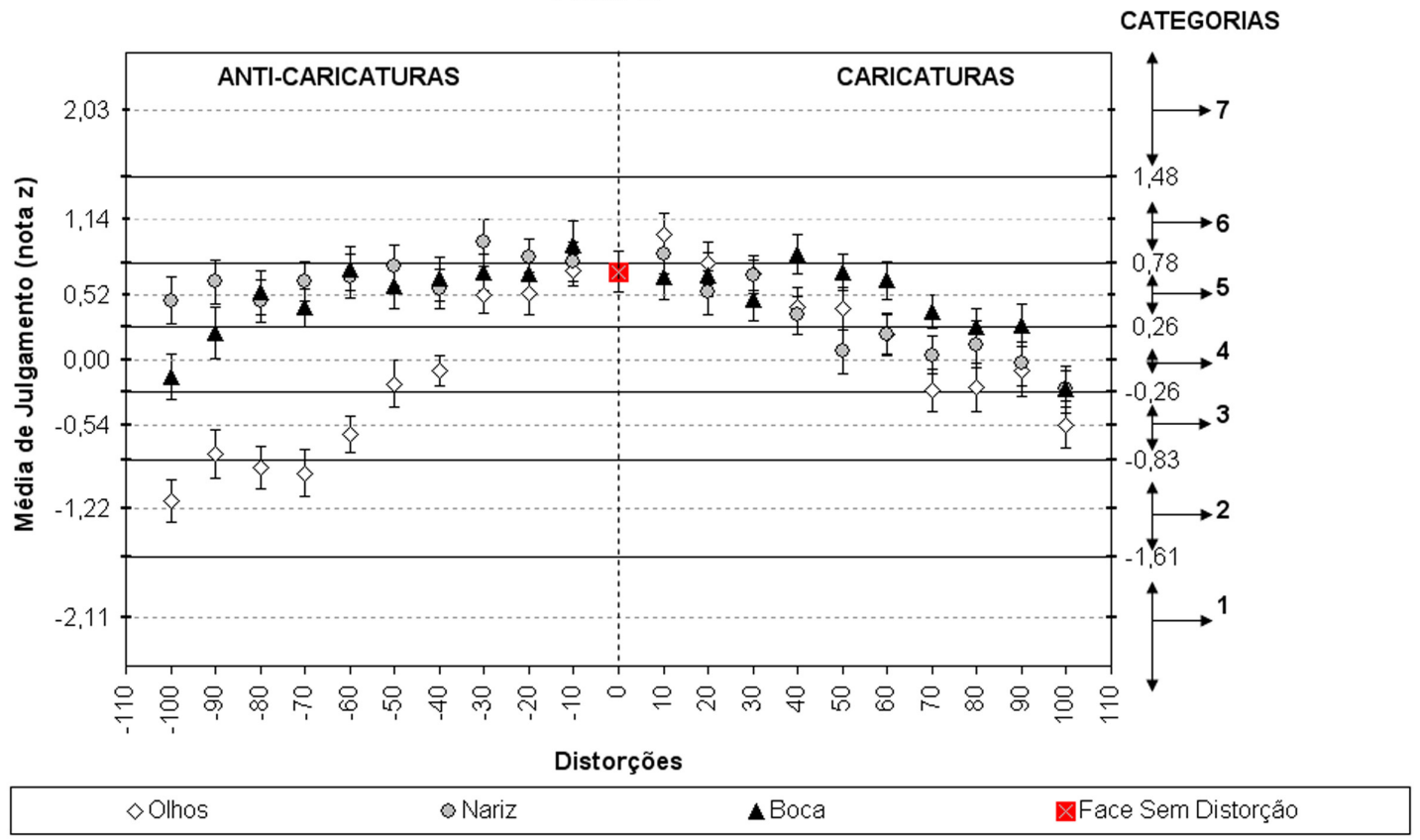

Face B

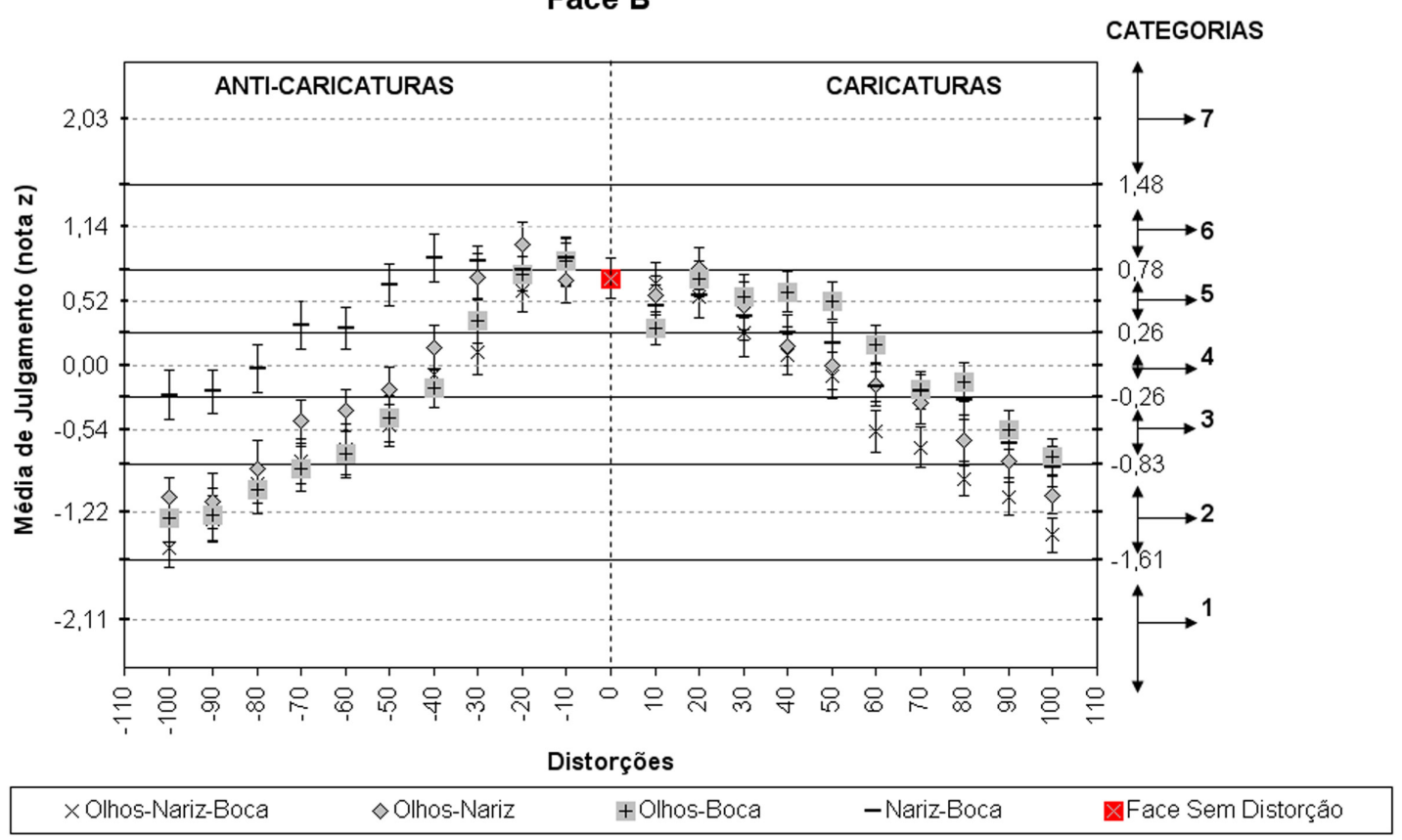

Figura 2.3.2 (B):: Gráficos das médias dos julgamentos com os respectivos erros-padrão da média em função das distorções para a Face B. Acima têm-se o gráfico das distorções para elementos faciais isolados, abaixo têm-se o gráfico para as distorções dos elementos faciais combinados. No eixo das ordenadas, à esquerda, encontram-se os pontos médios das categorias em nota $z$, à direita temse a extensão de cada categoria de julgamento. No eixo da abcissa têm-se dos elementos faciais em relação ao protótipo de cor branca. Quanto mais próximo a média de julgamento se encontra da categoria 7, maior a similaridade julgada entre a imagem distorcida e a face memorizada. 
Face C

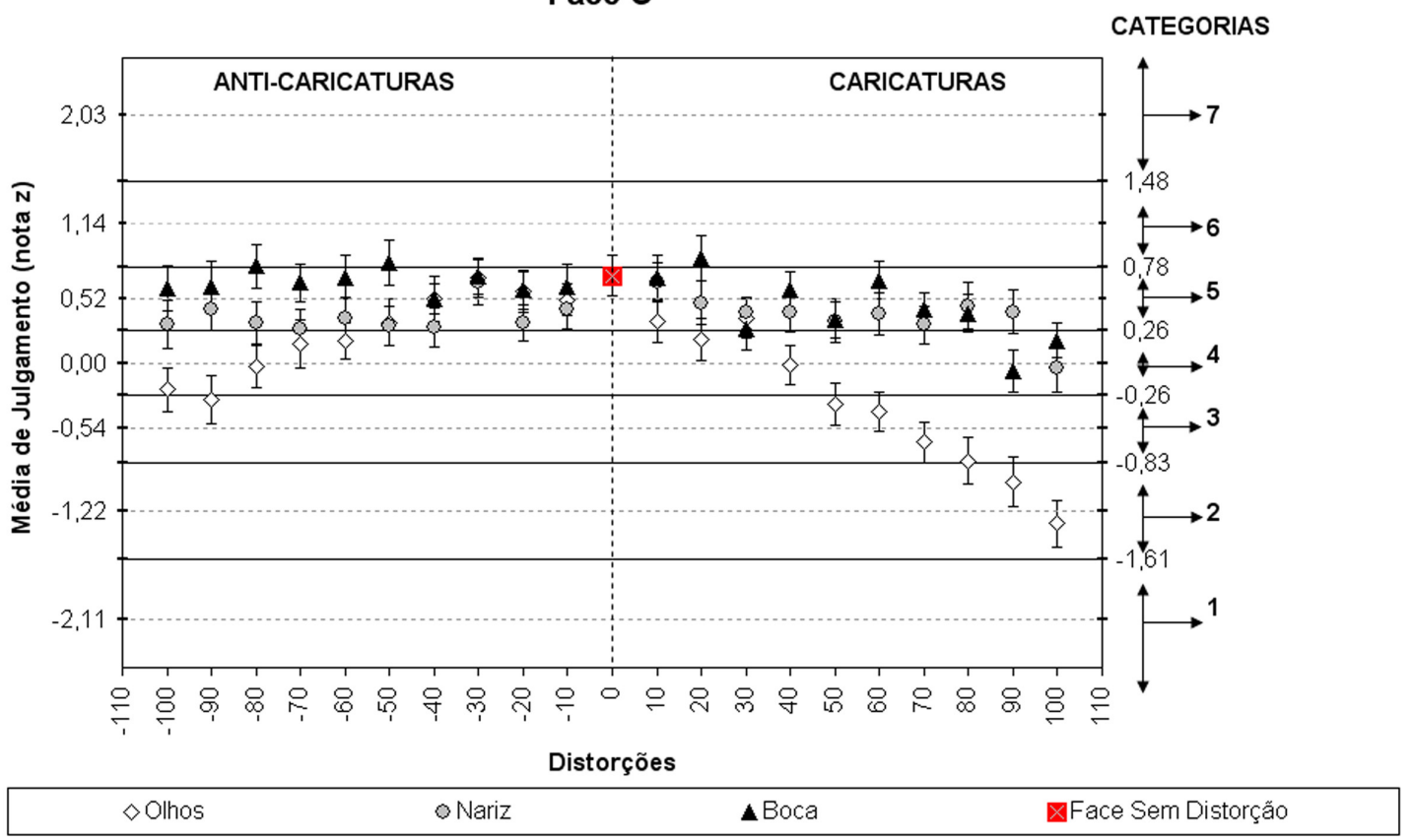

Face C

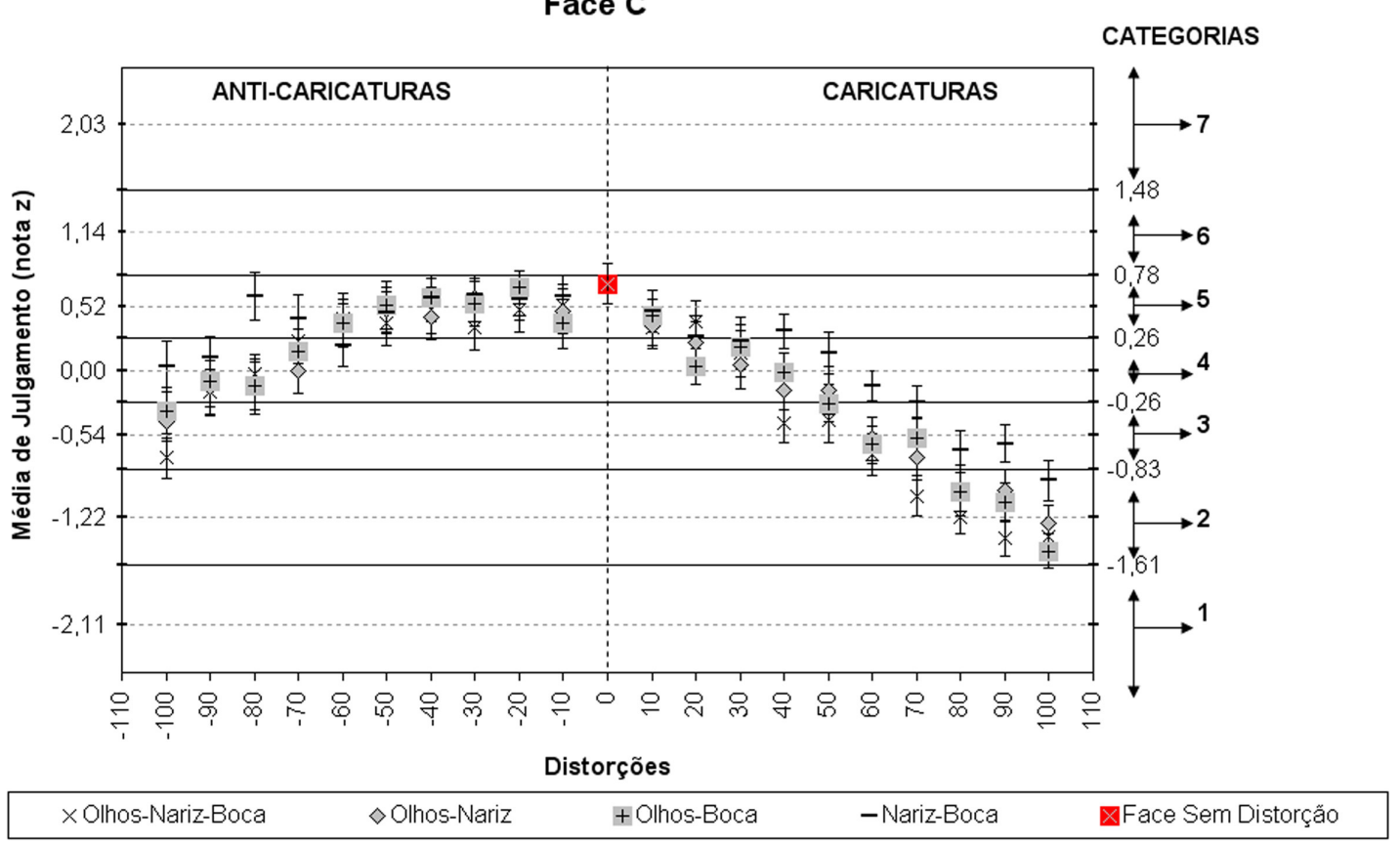

Figura 2.3.2 (C): Gráficos das médias dos julgamentos com os respectivos erros-padrão da média em função das distorções para a Face C. Acima têm-se o gráfico das distorções para elementos faciais isolados, abaixo têm-se o gráfico para as distorções dos elementos faciais combinados. No eixo das ordenadas, à esquerda, encontram-se os pontos médios das categorias em nota z, à direita tem-se a extensão de cada categoria de julgamento. No eixo da abcissa têm-se dos elementos faciais em relação ao protótipo de cor branca. Quanto mais próximo a média de julgamento se encontra da categoria 7, maior a similaridade julgada entre a imagem distorcida e a face memorizada. 
Face D

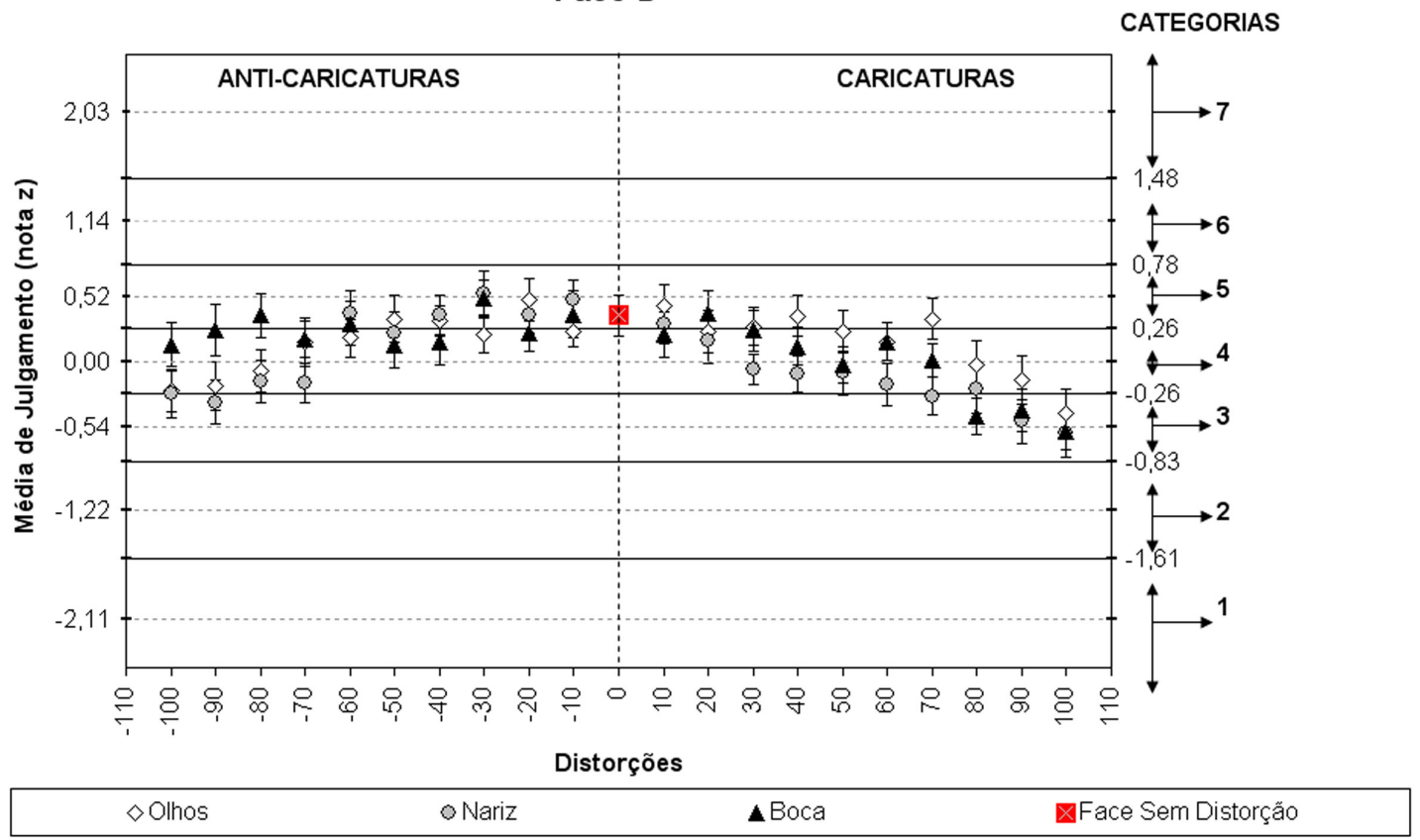

Face D

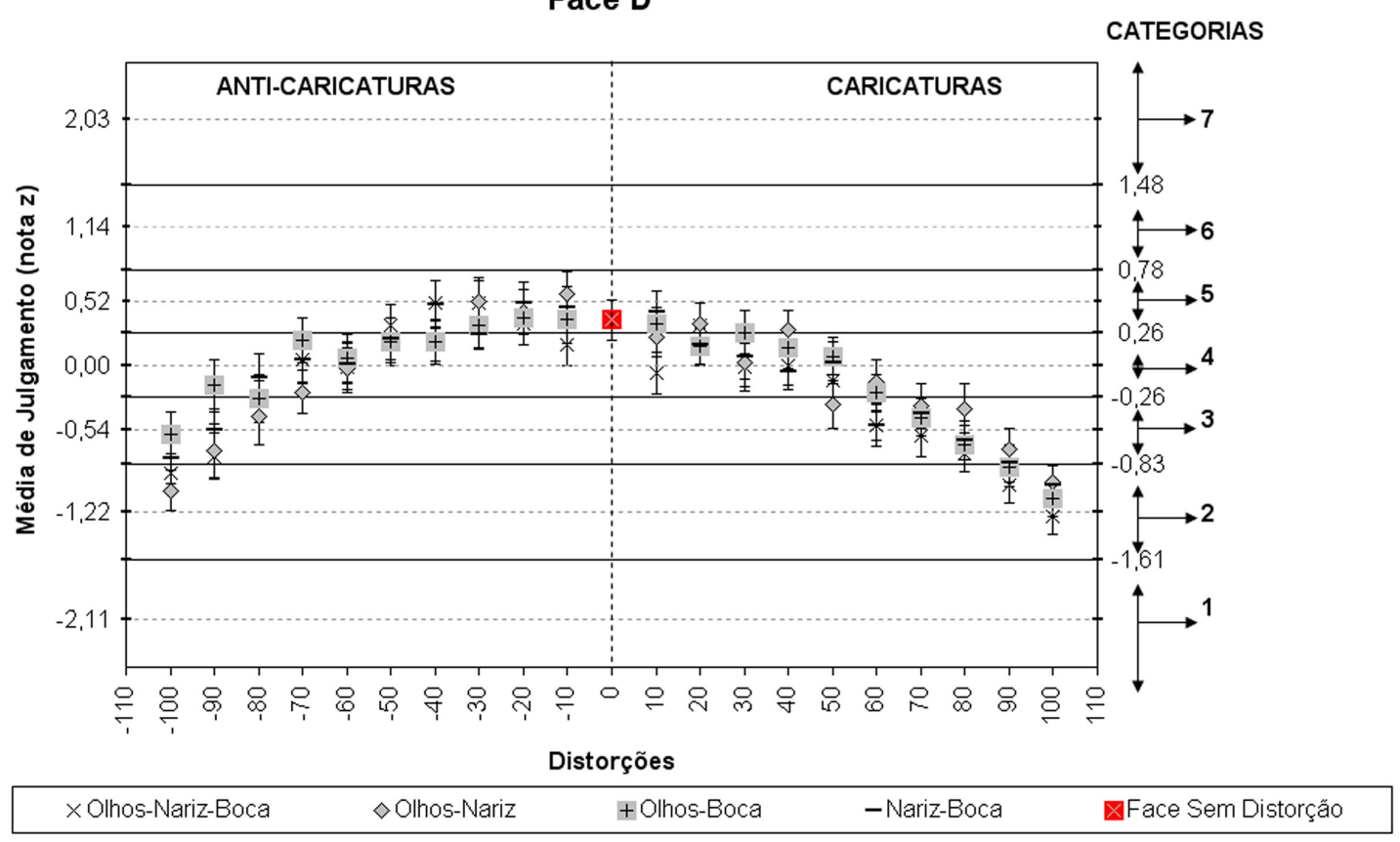

Figura 2.3.2 (D): Gráficos das médias dos julgamentos com os respectivos erros-padrão da média em função das distorções para a Face D. Acima têm-se o gráfico das distorções para elementos faciais isolados, abaixo têm-se o gráfico para as distorções dos elementos faciais combinados. No eixo das ordenadas, à esquerda, encontram-se os pontos médios das categorias em nota $\mathrm{z}$, à direita tem-se a extensão de cada categoria de julgamento. No eixo da abcissa têm-se dos elementos faciais em relação ao protótipo de cor branca. Quanto mais próximo a média de julgamento se encontra da categoria 7 , maior a similaridade julgada entre a imagem distorcida e a face memorizada. 
Do mesmo modo que na análise dos resultados do Experimento I, estimou-se o d' (parâmetro de discriminação da Teoria de Detecção de Sinal) para a relação entre cada distribuição das distorções e a distribuição da face sem distorção segundo as recomendações de Macmillan e Creelman (1991). O d' acumulado foi traçado em função das distorções dos elementos faciais isolados e de suas combinações e podem ser observados na Figura 2.3.3. O d’ igual a 1 foi adotado como o critério de separação entre as duas distribuições (limiar de dissimilaridade) e este se posiciona sob a distribuição da face original. O PIS corresponde ao ponto em que d' se iguala a zero.
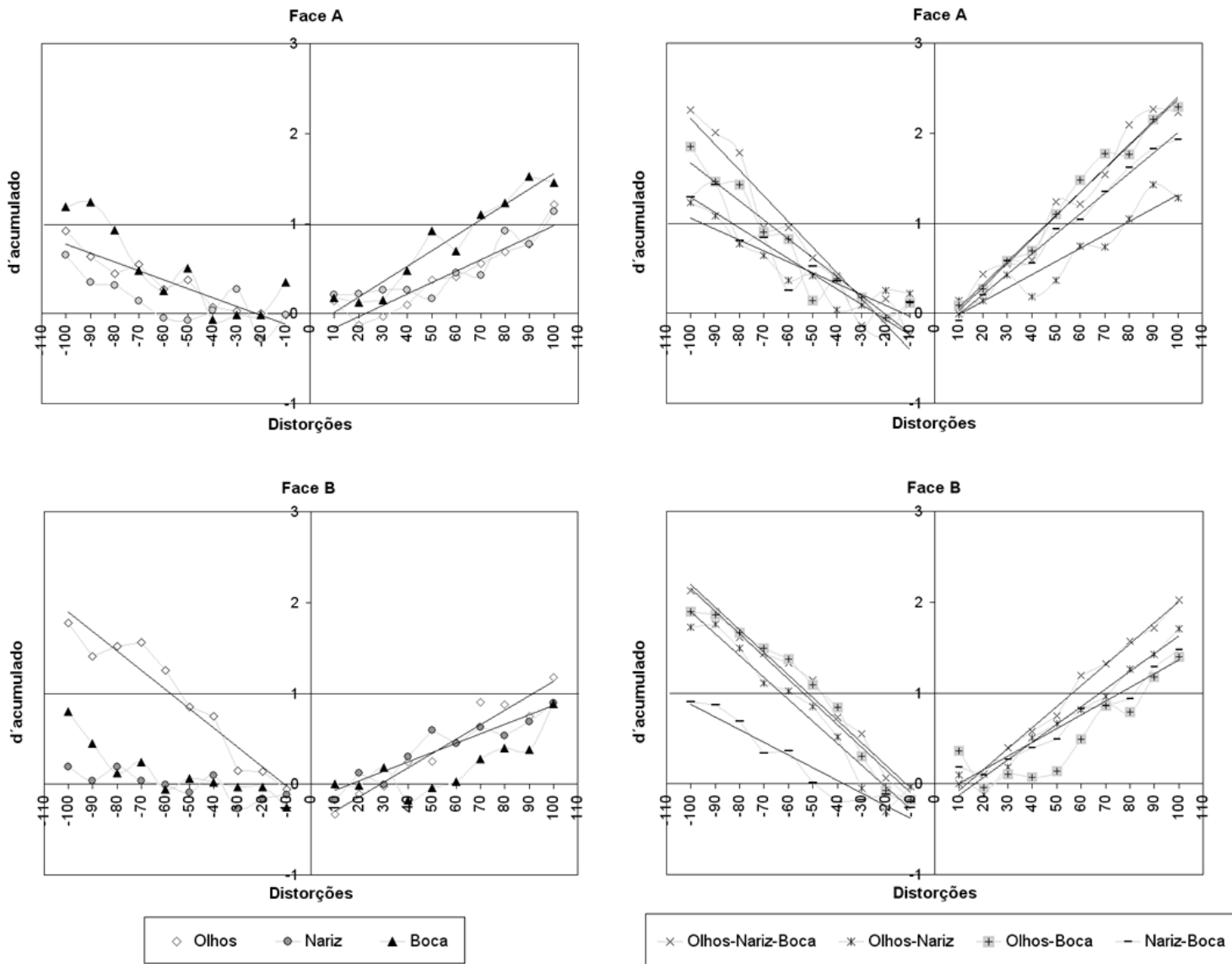

Figura 2.3.3 (A): À esquerda, gráfico de d' acumulado em função das distorções dos elementos faciais Faces A e B. À direita, gráfico de d' acumulado em função das distorções das combinações dos elementos faciais Faces A e B. $d^{\prime}$ igual a 1 indica o limiar de dissimilaridade. $d^{\prime}$ igual a 0 corresponde ao ponto de igualdade subjetiva (PIS). As retas de regressão representadas no gráfico correspondem às regressões cujos $R^{2}>0,80$. 

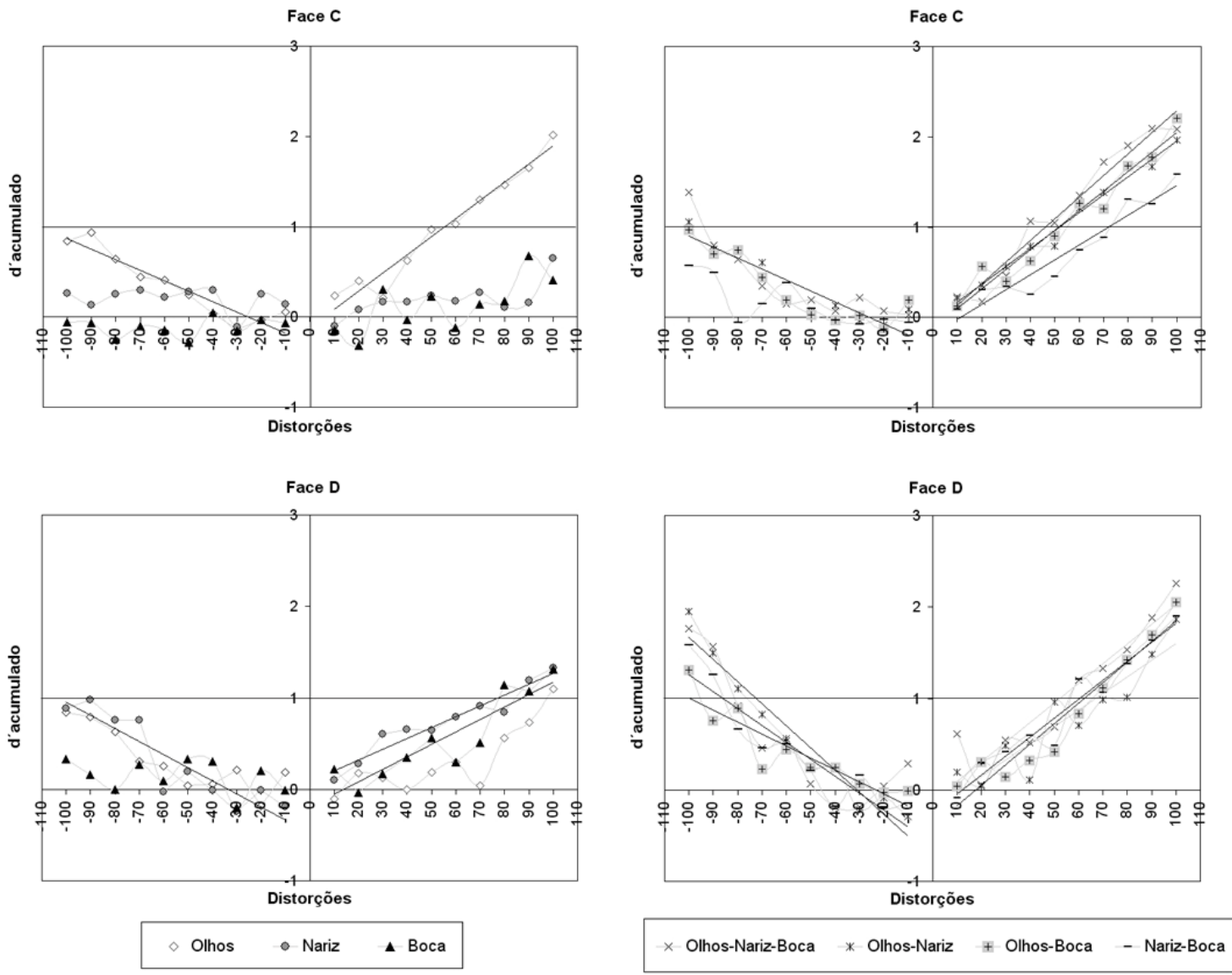

Figura 2.3.3 (B): À esquerda, gráfico de d' acumulado em função das distorções dos elementos faciais Faces A e B. À direita, gráfico de d'acumulado em função das distorções das combinações dos elementos faciais Faces C e D. $d^{\prime}$ igual a 1 indica o limiar de dissimilaridade. $d^{\prime}$ igual a 0 corresponde ao ponto de igualdade subjetiva (PIS). As retas de regressão representadas no gráfico correspondem às regressões cujos $R^{2}>0,80$.

Os pontos de igualdade subjetiva $\left(d^{\prime}=0\right)$ apresentados em números na Tabela 2.3.3 e em forma de gráfico na Figura 2.3.4, e os limiares de dissimilaridade $\left(d^{\prime}=1\right)$ apresentados na Figura 2.3.5 foram estimados de duas formas distintas: 1. utilizando-se a equação da reta de regressão do d' acumulado (fx) em função dos graus de distorção (x) (Tabela 2.3.2) cujos coeficientes de determinação $\left(R^{2}\right)$ foram maiores que 0,8 ; 2. por interpolação linear nos casos em que a equação da reta não define a relação entre d'acumulado e graus de distorção.

$\mathrm{Na}$ Tabela 2.3.3 nota-se que os PISs das Faces A e C foram maiores para as anticaricaturas que para as caricaturas. O maior PIS para as Faces A, C e D foi para as anti- 
caricaturas do nariz. Ainda na Tabela 2.3.3 observa-se que o maior PIS da Face B foi para a caricatura em que a região dos olhos foi exagerada.

Observando-se os resultados dos limiares de dissimilaridade (Figura 2.3.5) nota-se que o intervalo entre os limiares de dissimilaridade das caricaturas e anti-caricaturas foi menor na situação em que se manipulou a combinação dos três elementos faciais. Os resultados desses limiares para as Faces A, C e D indicam uma tendência de se julgar as anticaricaturas como mais parecidas com a face memorizada. Por outro lado, para a Face B, houve tendência de se julgar as caricaturas como mais parecidas com a face memorizada, principalmente para aquelas em que região dos olhos foi distorcida isoladamente ou em conjunto com outros elementos.

Nota-se ainda que algumas distribuições não se diferiram da distribuição da fotografia da face original (limiar de dissimilaridade acima de 100\%). Foi o caso das seguintes distribuições: 1. caricaturas e anti-caricaturas de nariz e anti-caricaturas de olhos da Faces A; 2. caricaturas e anti-caricaturas de nariz, caricaturas e anti-caricaturas de boca, anticaricatura da combinação de nariz e boca para a Face B; 3. caricaturas de nariz, caricatura de boca e todas as anti-caricaturas da Face C; caricatura e anti-caricatura de olhos, anticaricaturas de nariz, anti-caricaturas de boca, anti-caricaturas da combinação olhos e boca para a Face D. 
Tabela 2.3.2: Equações das retas de regressão e respectivos $R^{2}$ para cada caricaturas e anticaricaturas dos elementos faciais e suas combinações de cada uma das faces.

\begin{tabular}{|c|c|c|c|c|c|c|}
\hline & & & Face A & Face B & Face C & Face D \\
\hline & Olhos-Nariz & 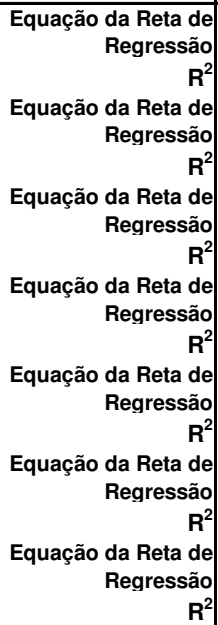 & $\begin{array}{l}f(x)=0,0126 x-0,2869 \\
R^{2}=0,8705 \\
f(x)=0,0098 x-0,0597 \\
R^{2}=0,7676 \\
f(x)=0,0171 x-0,1578 \\
R^{2}=0,9283 \\
f(x)=0,0264 x-0,2371 \\
R^{2}=0,9639 \\
f(x)=0,0148 x-0,1671 \\
R^{2}=0,8835 \\
f(x)=0,0258 x-0,1978 \\
R^{2}=0,984 \\
f(x)=0,0225 x-0,2431 \\
R^{2}=0,9872\end{array}$ & $\begin{array}{l}f(x)=0,016 x-0,4588 \\
R^{2}=0,9404 \\
f(x)=0,0104 x-0,1696 \\
R^{2}=0,8713 \\
f(x)=0,0081 x-0,2519 \\
R^{2}=0,6198 \\
f(x)=0,0231 x-0,3022 \\
R^{2}=0,9911 \\
f(x)=0,0195 x-0,3239 \\
R^{2}=0,966 \\
f(x)=0,0145 x-0,2652 \\
R^{2}=0,7766 \\
f(x)=0,0152 x-0,1519 \\
R^{2}=0,9512\end{array}$ & $\begin{array}{l}f(x)=0,0201 x-0,1152 \\
R^{2}=0,9592 \\
f(x)=0,0044 x-0,0529 \\
R^{2}=0,4868 \\
f(x)=0,0069 x-0,248 \\
R^{2}=0,5015 \\
f(x)=0,024 x-0,1076 \\
R^{2}=0,9605 \\
f(x)=0,0198 x-0,0312 \\
R^{2}=0,9834 \\
f(x)=0,0217 x-0,1163 \\
R^{2}=0,9558 \\
f(x)=0,0164 x-0,1843 \\
R^{2}=0,9261\end{array}$ & $\begin{array}{l}f(x)=0,0104 x-0,2594 \\
R^{2}=0,6962 \\
f(x)=0,0118 x+0,0857 \\
R^{2}=0,9253 \\
f(x)=0,0137 x-0,1944 \\
R^{2}=0,8176 \\
f(x)=0,0215 x-0,1217 \\
R^{2}=0,8808 \\
f(x)=0,0182 x-0,2177 \\
R^{2}=0,8507 \\
f(x)=0,0225 x-0,4016 \\
R^{2}=0,9292 \\
f(x)=0,0208 x-0,2553 \\
R^{2}=0,9517\end{array}$ \\
\hline 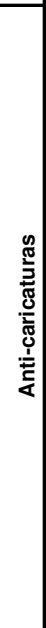 & Olhos-Nariz-Boca & 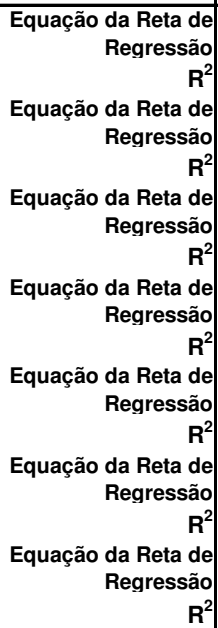 & $\begin{array}{l}f(x)=-0,0098 x-0,2129 \\
R^{2}=0,8973 \\
f(x)=-0,0066 x-0,2301 \\
R^{2}=0,5611 \\
f(x)=-0,0136 x-0,2637 \\
R^{2}=0,7155 \\
f(x)=-0,0285 x-0,6902 \\
R^{2}=0,9437 \\
f(x)=-0,0122 x-0,1579 \\
R^{2}=0,8061 \\
f(x)=-0,0211 x-0,435 \\
R^{2}=0,8947 \\
f(x)=-0,017 x-0,4101 \\
R^{2}=0,8313\end{array}$ & $\begin{array}{l}f(x)=-0,0213 x-0,237 \\
R^{2}=0,9223 \\
f(x)=-0,0038 x-0,2202 \\
R^{2}=0,5941 \\
f(x)=-0,0086 x-0,3402 \\
R^{2}=0,7476 \\
f(x)=-0,0249 x-0,2951 \\
R^{2}=0,978 \\
f(x)=-0,0242 x-0,5217 \\
R^{2}=0,9433 \\
f(x)=-0,025 x-0,3489 \\
R^{2}=0,9514 \\
f(x)=-0,014 x-0,5262 \\
R^{2}=0,8994\end{array}$ & $\begin{array}{l}f(x)=-0,0116 x-0,293 \\
R^{2}=0,8803 \\
f(x)=-0,0013 x+0,1326 \\
R^{2}=0,0944 \\
f(x)=0,0005 x-0,0815 \\
R^{2}=0,0259 \\
f(x)=-0,0122 x-0,2799 \\
R^{2}=0,734 \\
f(x)=-0,0122 x-0,3169 \\
R 2=0,8472 \\
f(x)=-0,0109 x-0,2864 \\
R^{2}=0,759 \\
f(x)=-0,0062 x-0,1953 \\
R^{2}=0,5719\end{array}$ & $\begin{array}{l}f(x)=-0,0096 x-0,2135 \\
R^{2}=0,738 \\
f(x)=-0,0143 x-0,4781 \\
R^{2}=0,8221 \\
f(x)=-0,002 x+0,0345 \\
R^{2}=0,1217 \\
f(x)=-0,0193 x-0,5393 \\
R^{2}=0,7196 \\
f(x)=-0,0242 x-0,7512 \\
R^{2}=0,9433 \\
f(x)=-0,0131 x-0,307 \\
R^{2}=0,8161 \\
f(x)=-0,0185 x-0,5837 \\
R^{2}=0,8546\end{array}$ \\
\hline
\end{tabular}


Tabela 2.3.3: Pontos de Igualdade Subjetiva (PIS) dos elementos faciais e suas combinações para cada uma das faces.

\begin{tabular}{|c|c|c|c|c|c|}
\hline \multirow{8}{*}{ 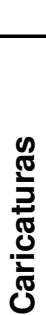 } & & Face A & Face B & Face C & Face D \\
\hline & Olhos & 1,00 & 28,68 & 5,73 & 13,80 \\
\hline & Nariz & & 16,31 & 15,60 & \\
\hline & Boca & 9,23 & 20,77 & 25,00 & 14,19 \\
\hline & Olhos-Nariz-B & 8,98 & 13,08 & 4,48 & 5,66 \\
\hline & Olhos- & 11,29 & 16,61 & 1,58 & 11,96 \\
\hline & Olh & 7,67 & 18,29 & 5,36 & 17,85 \\
\hline & Nari & 10,80 & 9,99 & 11,24 & 12,27 \\
\hline \multirow{7}{*}{ 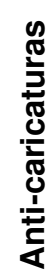 } & Ihos & $-21,72$ & $-11,13$ & $-25,26$ & $-15,00$ \\
\hline & ariz & $-25,09$ & $-37,50$ & $-32,50$ & $-33,43$ \\
\hline & Boca & $-17,55$ & $-36,50$ & $-25,00$ & $-10,40$ \\
\hline & Olhos-Nariz-Boca & $-24,22$ & $-11,85$ & $-5,00$ & $-21,40$ \\
\hline & Olhos-Nariz & $-12,94$ & $-21,56$ & $-25,98$ & $-31,04$ \\
\hline & Olhos-Bo & $-20,62$ & $-13,96$ & $-26,28$ & $-23,44$ \\
\hline & Nariz-Boca & $-24,12$ & $-37,59$ & $-31,50$ & $-31,55$ \\
\hline
\end{tabular}

*PIS indeterminado

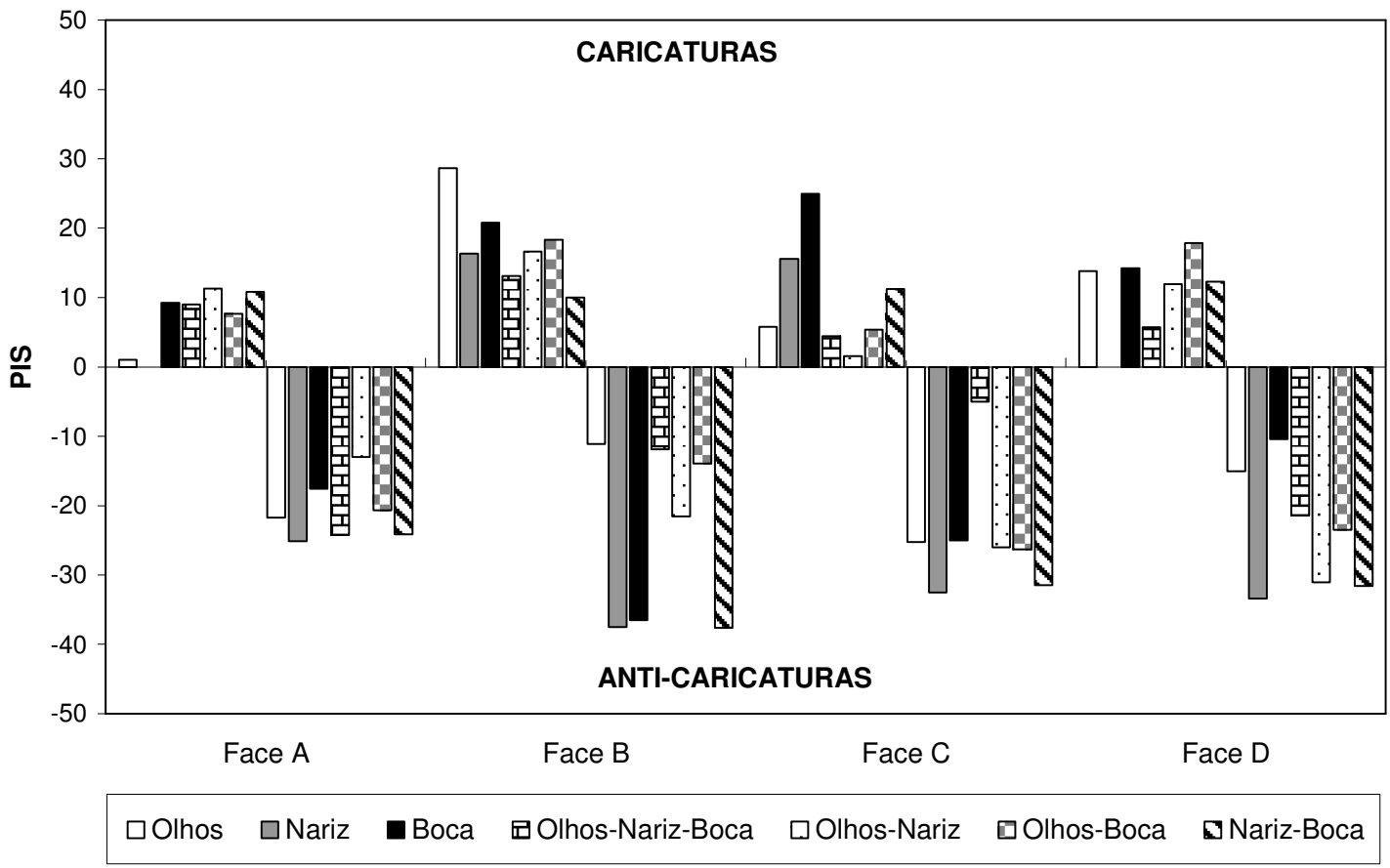

Figura 2.3.4: Representação gráfica dos PIS de cada elemento facial e suas combinações para todas as faces 


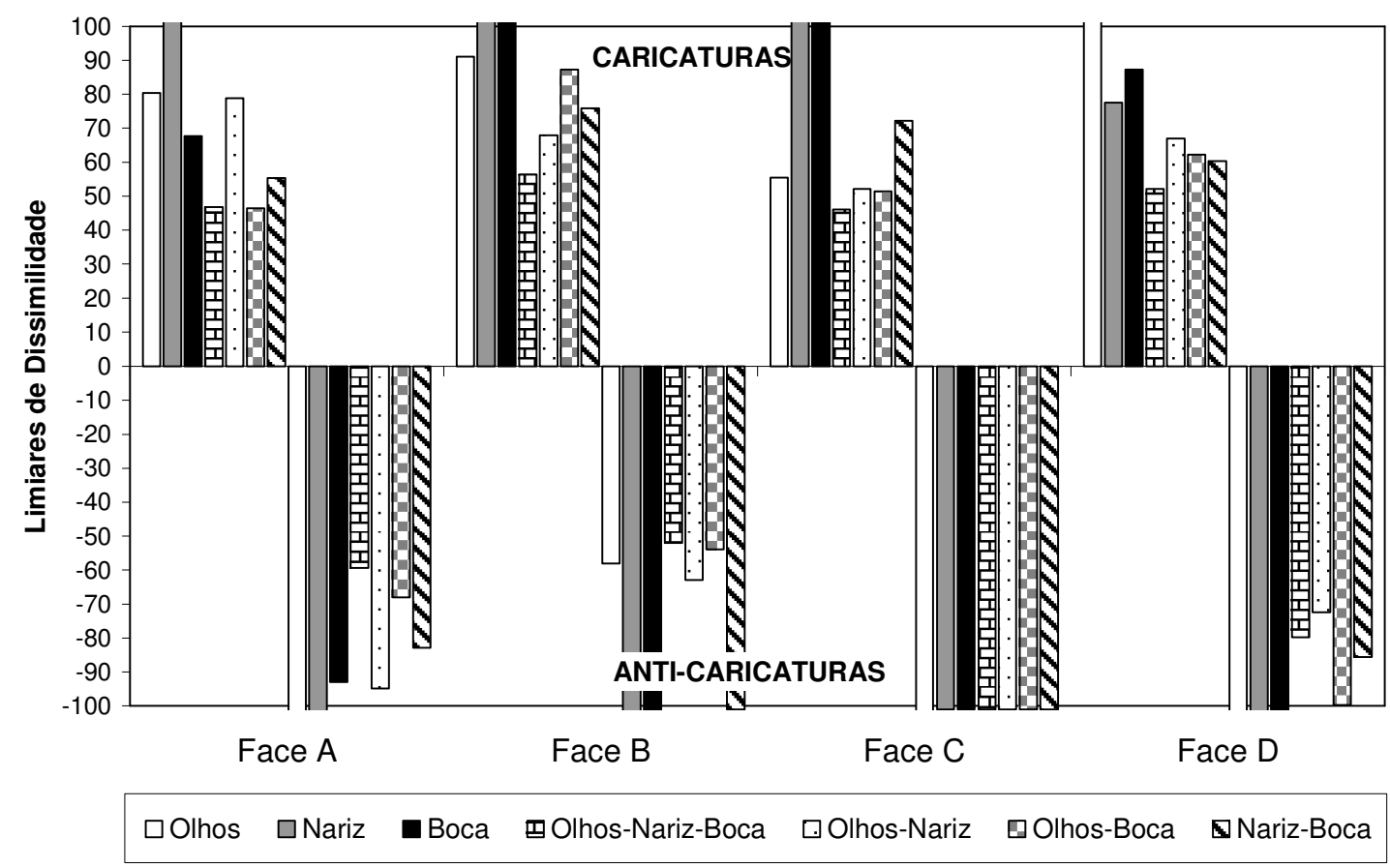

Figura 2.3.5: Graus de distorção quando d' igual a 1 para as caricaturas e anti-caricaturas dos elementos faciais e suas combinações de cada face. Acima do eixo das abcissas têm-se as distorções para as caricaturas, abaixo para as anti-caricaturas. As barras que extrapolam a margem do gráfico indicam que o limiar de dissimilaridade calculada é maior que 100\%, maior portanto, que a distorção máxima utilizada no experimento.

\subsubsection{Tempo de Reação}

Similarmente ao Experimento I, foram estimadas as médias do tempo de reação dos participantes nas anti-caricaturas e caricaturas para cada uma das quatro faces (Figura 2.3.6). As médias dos tempos de reação das caricaturas e anti-caricaturas de cada uma das combinações de elementos faciais foram submetidas ao teste de normalidade Shapiro-Wilk e obteve-se que suas distribuições tendem a normal ( $p>0,01)$. Dada a normalidade dos resultados, uma ANOVA para medidas repetidas (4 faces $\times 2$ tipos de distorção $\times 7$ combinações de elementos faciais) foi aplicada. De acordo com o teste estatístico utilizado, há diferença significativa entre as médias dos tempos de reação das faces $(\underline{F}(3,87)=3,537 ; \underline{p}<0,05)$ e entre as médias dos tempos de reação para as combinações dos elementos faciais $(\underline{F}(6,174)=3,658 ; \underline{p}<0,01)$. O teste indicou não haver efeito significativo do fator distorção $(\underline{F}(1,29)=2,527, p>0,05)$ nem de quaisquer das possíveis efeitos das interações entre os fa- 
tores ( $p>0,05)$. Na Figura 2.3.6 pode-se notar que o menor tempo de reação tende a ser para as figuras em que todos os elementos faciais foram distorcidos.

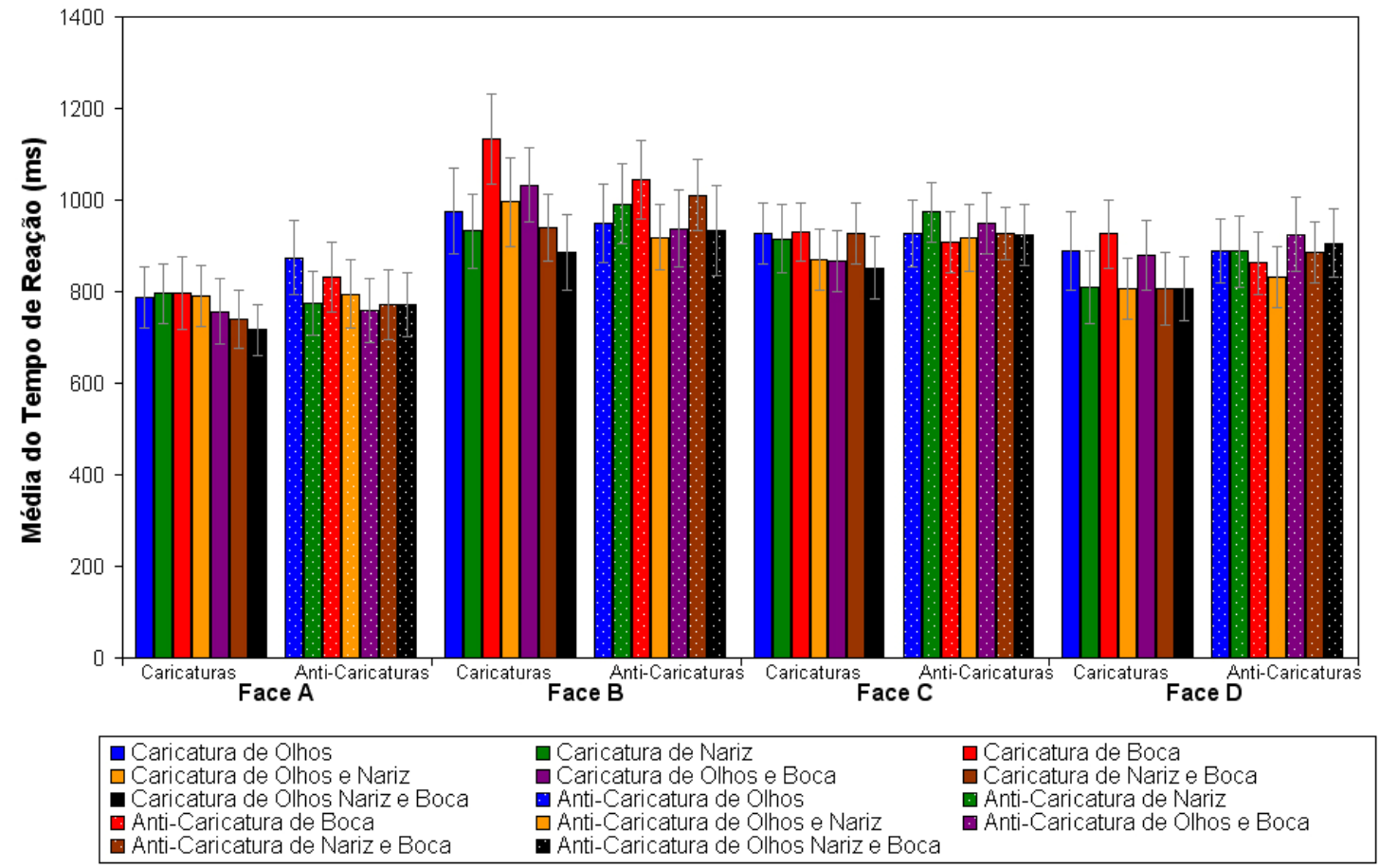

Figura 2.3.6: Gráfico de colunas das médias do tempo de reação (em milisegundos) com os respectivos erros padrão da média, das anti-caricaturas e caricaturas dos elementos faciais e suas combinações em função das quatro faces.

\subsubsection{Discussão}

Neste experimento pôde-se investigar a diferença no julgamento de similaridade quando os elementos faciais isolados, ou a combinação desses, foram manipulados. Os resultados indicam que, quanto mais elementos são manipulados menor a distorção necessária para diferenciação entre a imagem distorcida e a face original. Outra evidência dos resultados diz respeito à área da diferença entre os elementos faciais e o protótipo, sendo que quanto maior a área dessa diferença, menos o elemento pode ser manipulado. Segundo o modelo do espaço multidimensional, a diferença entre a face e o protótipo revela sua peculiaridade. Sendo assim, pode-se inferir que os elementos faciais isolados mais típicos carregam informações importantes sobre a face, e quando as configurações espaciais entre es- 
ses elementos são acrescentadas às informações sobre a face ficam ainda mais consistentes.

Uma observação que embasa esta resposta provém da análise dos julgamentos de similaridade das imagens em que o elemento facial boca foi manipulado. A Face A, a que possui esse elemento como o mais peculiar entre as quatro, apresentou o menor limiar de dissimilaridade na condição em que esse elemento foi manipulado isoladamente. Ainda para a Face $A$, os limiares de dissimilaridade são menores na condição em que a combinação dos elementos faciais continha o elemento peculiar (boca). Para essa face houve tendência das anti-caricaturas serem julgadas como mais similares à face original que as caricaturas.

Os resultados para a Face B também sustentam a afirmação de que quanto mais elementos peculiares manipulados, menor o limiar de dissimilaridade. Numa comparação entre as quatro faces, a Face B é a que tem maior peculiaridade da região dos olhos. Adicionando-se resultados oriundos dos julgamentos de similaridade, tem-se que os intervalos entre os limiares de dissimilaridade das caricaturas e anti-caricaturas que envolveram essa região da Face B é menor que as demais. Em se tratando dos resultados dos julgamentos para a Face $B$, tem-se vantagem da caricatura sobre as anti-caricaturas. A distorção em que as distribuições dos julgamentos em que a região dos olhos foi caricaturada isoladamente, ou as combinações que contém essa região se diferenciam da distribuição dos julgamentos da face original é menor que o limiar de dissimilaridade para a condição em que os demais elementos faciais e suas combinações foram manipulados.

Quando o elemento facial manipulado foi o nariz, com exceção da Face D que dentre as quatro faces possui o nariz mais peculiar, não houve diferenciação da similaridade entre a face original e as imagens distorcidas. Para a Face D, as distorções no sentido do protótipo, anti-caricatura, são maiores que as distorções em que a peculiaridade foi acentuada, caricatura.

A análise dos dados resultantes do julgamento de similaridade para a Face C, somados à análise da área da diferença entre a face original e o protótipo, indicam que o elemento facial mais peculiar dessa face é região dos olhos. Caricaturas em que essa região, assim 
como as combinações que contém a região dos olhos, foram manipuladas permitem menor distorção que os demais. Anti-caricaturas não se diferenciaram da face original. Uma vez que a Face $C$ é a que possui os elementos faciais mais típicos, levanta-se a hipótese de que as diferenças entre a face manipulada e o protótipo não são suficientes para se encontrar vantagem da caricatura.

Em suma, tem-se que a diferenciação entre as imagens distorcidas e a face original é melhor quando todos os elementos faciais são distorcidos em detrimento dos elementos isolados. Porém, quando o elemento peculiar da face está envolvido na manipulação houve maior redução da similaridade com a face original que a manipulação de elementos mais típicos.

Os resultados relativos aos tempos de reação apontam diferenças significativas entre as faces e os elementos faciais. O menor tempo de reação foi encontrado para a condição em que todos os elementos faciais foram distorcidos. Isso indica que quanto mais elementos faciais, mais fácil deve ser o julgamento de similaridade. Provavelmente porque as combinações dos elementos fornecem pistas sobre a relação entre os elementos faciais o que facilita o julgamento de similaridade . 


\section{DISCUSSÃO GERAL}

Um dos objetivos desta pesquisa consistiu na criação do banco de dados com faces brasileiras. Ele foi necessário para a construção das faces prototípicas, a partir destas as caricaturas e anti-caricaturas, e pode ser utilizado em outras pesquisas sobre percepção e reconhecimento de faces desenvolvidas no Brasil. A falta de familiaridade com faces estrangeiras pode enviesar pesquisas em atratividade e reconhecimento, o que inviabiliza a utilização de faces de não-brasileiros nesse tipo de estudo quando os dados são coletados aqui.

Também como parte dos objetivos iniciais, os primeiros protótipos derivados de amostras da população brasileira foram criados. Suas validações, além da indicação de como eles podem ser utilizados em outras investigações sobre atratividade e reconhecimento de faces, podem ser encontradas com mais detalhes no artigo anexado (Apêndice E).

Com o Experimento I, investigou-se se caricaturas holísticas com qualidade fotográfica são imagens que representam melhor a face que uma fotografia sem distorção. Os resultados dessa pesquisa sugerem que não, que as caricaturas com qualidade fotográfica tendem a ser julgadas tão similares às faces memorizadas quanto as faces originais e, em alguns casos, as anti-caricaturas aproximam-se mais à face original que as caricaturas. Experimentos utilizando a caricatura em forma de traço revelam o contrário (Rhodes et al., 1987, Rhodes et al., 1996), que elas são mais fidedignas às faces conhecidas do que o desenho fiel à forma da face. A fotografia fornece informações sobre os aspectos tridimensionais da face como textura, sombra, contraste e, conseqüentemente, sobre os aspectos holísticos da face que parecem essenciais para sua percepção. Por outro lado, o desenho reduz a informação da configuração da face (Leder, 1996) que, no caso da caricatura em forma de traço, seria compensado pelo aumento da peculiaridade. Portanto, quando as informações sobre a tridimensionalidade da face não estão presentes, o cérebro deve utilizar as informações sobre as formas peculiares. Sendo assim, a caricatura em forma de traço é melhor que o de- 
senho fiel da face por exagerar essas características peculiares e facilitar o acesso à imagem facial armazenada na memória. Em contrapartida, quando os aspectos tridimensionais da face estão presentes, o exagero das características faciais peculiares é pouco eficaz. Desta forma, o cérebro parece não utilizar os exageros para acessar faces quando se tem informações sobre seus aspectos holísticos.

Como os resultados do Experimento I não evidenciam a vantagem da caricatura sobre a face original, não foi encontrado um grau de distorção para que essa vantagem ocorra. Os resultados sugerem que, para algumas faces, as caricaturas são julgadas como tão similares à face memorizada quanto sua fotografia sem distorção. Para outras faces, as anticaricaturas tendem a ser julgadas como tão similares à face memorizada quanto a fotografia original. Benson \& Perret (1991b) encontraram resultados similares em seus experimentos. Eles submeteram caricaturas e anti-caricaturas com qualidade fotográfica e a fotografia original de faces de pessoas famosas a experimentos em que os sujeitos escolhiam a melhor representação da face conhecida. Na média encontrou-se a vantagem da caricatura. Porém, analisando-se face por face, encontrou-se que, para algumas pessoas a melhor representação é a fotografia original, para outras a caricatura e para um terceiro grupo de faces havia uma tendência de se escolher a anti-caricatura como sua melhor representação.

Portanto, uma provável explicação para a diferença entre as tendências de similaridade das faces deve estar relacionada à tipicidade. A caricatura foi considerada como tão adequada quanto a face original apenas para a face mais peculiar entre as quatro faces utilizadas no Experimento I. Para as faces mais típicas, houve tendência das anti-caricaturas serem julgadas como mais parecidas com a face original que as caricaturas. Uma explicação para esses resultados seria que faces mais típicas estariam mais sujeitas a erro de codificação por estarem num local de muita densidade no espaço multidimensional. Assim, a representação que se tem da face não coincidiria com a imagem real e estaria sujeita a maior o erro de julgamento. Em contrapartida, faces mais peculiares estão numa área de menor densidade e são menos sujeitas a erros de codificação. Sugere-se que para que a caricatura seja uma representação adequada da face esta deve ser peculiar. 
Como já mencionado, resultados do Experimento I não evidenciam a vantagem da caricatura. Por isso, levanta-se a hipótese que as imagens faciais armazenadas em memória são representações fidedignas da face. E que a caricatura pode facilitar o acesso à informação quando a face está numa área de menor densidade do espaço multidimensional.

Também com o Experimento I objetivou-se investigar a relação dos três protótipos obtidos a partir de amostras da população brasileira com as caricaturas e conseqüentemente averiguar se os resultados favorecem ao modelo do espaço multidimensional para faces com codificação baseada na norma ou nos exemplares. O modelo com codificação baseada na norma supõe que: 1 . faces são representadas no espaço multidimensional baseadas no protótipo; 2. caricaturas são eficazes porque exageram o desvio em relação ao protótipo; 3. faces de outras etnias são codificadas em função da norma da etnia do observador; 4 . a similaridade entre as faces é uma medida vetorial. Desta forma, segundo o modelo baseado na norma, transformações apropriadas são aquelas feitas a partir do protótipo do julgador, independente da etnia da face manipulada. Diferentemente, o modelo de codificação baseado nos exemplares supõe que: 1 . faces são codificadas em função de seus valores absolutos; 2. caricaturas são eficazes porque minimizam a densidade dos exemplares; 3 . as dimensões do espaço multidimensional são impróprias para etnias diferentes da do observador; 4. a similaridade entre as faces é medida em função da distância euclidiana entre elas. Segundo esse modelo, apenas a manipulação da face feita a partir do protótipo da etnia da face manipulada é capaz de mover a face para uma área de menor densidade no espaço multidimensional.

Os resultados do Experimento I demonstram que há diferença no grau de distorção em que caricaturas e anti-caricaturas diferem da face original de acordo com o protótipo que as geraram. Como não houve vantagem da caricatura quando confeccionadas a partir do protótipo branco, infere-se que as distorções foram derivadas da comparação entre a face branca e o protótipo de mesma cor/raça não se mostraram eficazes em mover a face para uma área de menor densidade no espaço multidimensional. Faces localizadas nas áreas de menor densidade do espaço multidimensional tendem a ter menores tempos de reação, uma 
vez que o menor tempo de resposta foi para as distorções feitas a partir do protótipo de cor parda, infere-se que distorções feitas a partir do protótipo pardo foram as que mais moveram as faces para área de menor densidade no espaço multidimensional, corroborando o modelo da codificação baseada na norma.

Em tarefas de identificação, faces peculiares tendem a ter baixos tempos de reação. No Experimento I a face com menor tempo de reação foi a com maior área de diferença com relação ao protótipo. Parece, então, que a área da diferença entre a face e o protótipo é uma medida de sua peculiaridade, o que também evidencia a existência do protótipo.

No Brasil temos uma população miscigenada e amplo contato com pessoas de cores branca, parda e preta, o que deve fazer do protótipo do pardo o mais adequado para construção das caricaturas. Essa explicação demanda maiores investigações. Uma das tarefas que pode elucidar sobre o assunto é categorização de imagens da população brasileira entre face e não-face. Quanto mais rápido a resposta de categorização, mais próxima do protótipo.

Alguns estudos indicam que há diferença na importância dos elementos faciais na tarefa de identificação da face. Esses estudos mostram que a parte superior da face tem um papel central no processo de reconhecimento de faces (Lacroce, Brosgole \& Stanford, 1993). E que parece haver hierarquia dos elementos faciais para o reconhecimento. Haig (1984) realizou estudo em que mediu a importância de diferentes elementos faciais e encontrou que, para a identificação a ordem de importância seria: topo da cabeça, olhossobrancelha, boca e nariz. Outros estudos evidenciam que os elementos faciais não são igualmente distintos e conseqüentemente não têm o mesmo papel no reconhecimento de faces (Ellis, 1975, Bruce, Dench \& Burton, 1993). Os resultados do Experimento II apontam para a importância do processamento das características peculiares da face no julgamento da similaridade, mais do que uma hierarquia fixa desses elementos. Deste modo, a similaridade julgada entre a face distorcida e a face memorizada é menor quando se manipula os elementos peculiares da face. 
No que diz respeito à investigação de quais elementos faciais estão envolvidos no reconhecimento de faces, a comparação entre resultados dos Experimentos I e II favorecem a hipótese do processamento holístico de faces. Essa afirmação reside no fato do intervalo entre os limiares de dissimilaridade das caricaturas e anti-caricaturas serem menores para o Experimento I em que toda a face foi distorcida do que no Experimento II.

Os experimentos desta pesquisa estão longe de dar desfecho às questões de quais elementos faciais estão envolvidos no reconhecimento de faces e qual seria o melhor modelo para explicar o processo de codificação de faces. Entretanto, os resultados indicam evidências do processamento holístico da face. Os resultados também apontam que não há vantagem da caricatura quando a imagem fornece informações tridimensionais da face. Evidenciam também que a cor/raça da face interage com o efeito da caricatura. Propõe-se que a caricatura não mimetiza a forma de codificação de faces, mas que facilita o acesso às imagens armazenadas em memória de devem ser representações da face sem exageros. $E$ ainda que, para que a caricatura seja uma representação tão adequada quanto a fotografia original, a face deve ser peculiar. 


\section{REFERÊNCIAS BIBLIOGRÁFICAS}

Bartlett, J. C., Hurry, S., \& Thorley, W. (1984). Typicality and familiarity of faces. Memory \& Cognition, 12, 219-228.

Benson, P. J., \& Perrett, D. I. (1991a). Synthesising continuous-tone caricature. Image and Vision Computing, $\underline{9}, 123-129$.

Benson, P. J., \& Perrett, D. I. (1991b). Perception and recognition of photographic quality facial caricatures: implications for the recognition of natural images. European Journal of Cognitive Psychology, $\underline{3}$, 105-135.

Benson, P. J., \& Perrett, D. I. (1994). Visual processing of facial distinctiveness. Perception, $\underline{23}, 75-93$

Brennan, S. E. (1985). Caricature generator: the dynamic exaggeration of faces by computer. Leonardo, $\underline{18}, 170-178$.

Bruce, V., \& Young, A. (1998). In the eye of the beholder: The science of face perception. New York: Oxford University Press.

Bushnell, I. W. R., Sai, F., \& Mullin, J. T. (1989). Neonatal recognition of the mother's face. British Journal of Developmental Psychology, $\underline{7}, 3-15$.

Byatt, G., \& Rhodes, G. (1998). Recognition of own-race and other-race caricatures: implications for models of face recognition. Vision Research, $\underline{38}, 2455-2468$.

Campbell, R., \& Tuck, M. (1995). Recognition of parts of famous-face photographs by children: an experimental note. Perception, 24, 451-456.

Chiroro, P., \& Valentine, T. (1995). An investigation of the contact hypothesis of the own-race bias in face recognition. Quarterly Journal of Experimental Psychology, 48, 879-894.

Fonseca, J. (1999). Caricatura: a imagem gráfica do humor. Porto Alegre: Artes e Ofícios.

Gilbert, C., \& Bakan, P. (1973). Visual asymmetry in perception of faces. Neuropsychologia, $\underline{11}, 355-362$.

Grill-Spector, K., Knouf, N., \& Kanwisher, N. (2004). The fusiform face area subserves face perception, not generic within-category identification. Nature Neuroscience, $\underline{7}, 555-562$.

Guilford, J. P. (1954). Psychometric Methods. New York: McGraw-Hill Book Company.

Harmon, L. D. (1973). The recognition of faces. Scientific American, 277, 71-82. 
Johnson, D. H., Dziurawiec, S., Ellis, H., \& , Morton, J. (1991). Newborns' preferential track-

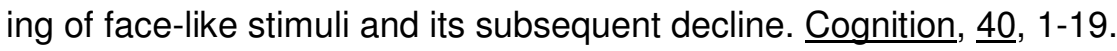

Kanwisher, N., McDermott, J., \& Chun, M. M. (1997). The fusiform face area: A module in human extrastriate cortex specialized for face perception. The Journal of Neuroscience, 17, 4302-4311.

Lacroce, M. S., Brosgole, L., \& Stanford, R. G. (1993). Discriminability of different parts of faces. Bulletin of the Psychonomic Society, 31, 329-331.

Leder, H. (1996). Line drawings of faces reduce configural processing. Perception, 25, 355366.

Lee, K., Byatt, G., \& Rhodes, G. (2000). Caricatures effects, distinctiveness, and identification: testing the face-space framework. Psychological Science, $11,379-385$.

Light, L. L., Kayra-Stuart, F., \& Hollander, S. (1979). Recognition memory for typical and unusual faces. Journal of Experimental Psychology: Human Learning and Memory, $\underline{5}$, 212-228.

Loffler, G., Yourganov, G., Wilkinson, F., \& Wilson, H. R. (2005). fMRI evidence for neural representation of faces. Nature Neuroscience, $\underline{8}, 1386-1390$.

McGurk, H., \& MacDonald, J. (1976). Hearing Lips and seeing voices. Nature, 264, 746-748.

McKone, E., Kanwisher, N., \& Duchaine, B. C. (2006). Can generic expertise explain special processing for faces? Trends in Cognitive Sciences, 11, 8-15.

Michelon, P., \& Biederman, I. (2003). Less impairment in face imagery than face perception in early prosopagnosia. Neuropsychologia, $\underline{41}$, 421-441.

Mondloch, C. J., Maurer, D. \& Ahola, S. (2006). Becoming a face expert. Psychological Science, $17,930-934$.

Redman, L. (1984). How to draw caricatures. Chicago: Contemporary Books.

Rhodes, G., Brennan, S., \& Carey, S. (1987). Identifications and ratings of caricatures: implications for mental representations of faces. Cognitive Psychology, $\underline{19}$, 473-497.

Rhodes, G., Byatt, G., Tremewan, T., \& Kennedy, A. (1996). Facial distinctiveness and the power of caricatures. Perception, 25, 207-223.

Rhodes, G., Carey, S., Byatt, G., \& Profifitt, F. (1998). Coding spatial variations in faces and simples shapes: a test of two models. Vision Research, $\underline{38}, 2307-2321$.

Tversky, B., \& Baratz, D. (1985). Memory for faces: Are caricatures better than photographs? Memory \& Cognition, $\underline{13}, 45-49$. 
Valentine, T. (1991). A unified account of the effects of distinctiveness, inversion and race in face recognition. The Quarterly Journal of Experimental Psychology, 43, 161-204.

Valentine, T., \& Bruce, V. (1986). The effects of distinctiveness in recognising and classifying faces. Perception, $\underline{15}$, 525-535.

Valentine, T., \& Endo, M. (1992). Towards an exemplar model of face processing: the effects of race and distinctiveness. The Quarterly Journal of Experimental Psychology, 44 , 671-703.

Winograd, E. (1981). Elaboration and distinctiveness in memory for faces. Journal of Experimental Psychology: Human Learning and Memory, $\underline{7}, 181-190$.

Young, A. W., Hellanwell, D. J., \& Hay, D. C. (1987). Configural information in face perception. Perception, $\underline{16}, 747-759$. 


\section{APÊNDICE A — CONFECÇÃO DOS PROTÓTIPOS}

Neste apêndice estão descritos os passos seguidos para a confecção dos protótipos. Primeiramente têm-se informações sobre o banco de dados e como as imagens que o compõem foram capturadas. Depois estão descritas informações sobre a técnica de morphing utilizada na fusão das imagens e o modo em que se fez a interpolação entre as imagens para se chegar aos protótipos.

\section{Captura de Imagens Faciais para formar o Banco de Dados}

\subsection{Doadores das imagens faciais}

817 adultos, de ambos os sexos, que se auto-declararam conforme as categorias de cor de pele do IBGE, a saber, branco, preto, pardo, amarelo e indígena, maiores de 18 anos, brasileiros residentes da região de Ribeirão Preto-SP, cientes de como suas imagens seriam utilizadas.

\subsection{Materiais e Aparatos}

Duas câmeras fotográficas da marca Sony ${ }^{\circledR}$, sendo uma modelo CyberShot ${ }^{\circledR}$ V1 e outra CyberShot® P100, ambas com 5.1 Megapixels de resolução foram utilizadas na captura das imagens faciais. Microcomputador Pentium ${ }^{\circledR} \mathrm{III}, 600 \mathrm{MHz}, 64 \mathrm{Mb}$ RAM, acoplado a um monitor de 21”, Phillips ${ }^{\circledR}$, modelo Brilliance $21 \mathrm{~A}$ foi utilizado para armazenar os dados.

\subsection{Procedimento}

Foram fotografados 817 voluntários residentes na região de Ribeirão Preto-SP. As fotografias foram obtidas pela pesquisadora e a colaboradora Kátia Cruvinel Arraes com as câmeras fotográficas digitais em pontos públicos da cidade, universidades particulares e centros culturais. As pessoas fotografadas assinaram o termo de autorização do uso da imagem (Apêndice C) contendo as informações sobre a pesquisa e como suas fotografias 
podem ser utilizadas. Também preencheram um questionário com dados de faixa etária e cor/raça. Logo em seguida, a imagem foi capturada com o voluntário sentado na posição frontal, instruído a ficar com expressão facial neutra e a câmera posicionada a 1,20 m de distância do voluntário, a distância focal ajustada para 24 mm (zoom de 3x) enquadrando-se o rosto e pescoço do voluntário e acionando-se o flash interno da câmera. Todas as imagens capturadas são coloridas e na resolução máxima do equipamento (5 Megapixels).

As fotografias foram catalogadas e agrupadas de acordo com sexo, os dados de auto-declaração de cor/raça e a idade da pessoa na ocasião da fotografia e estão armazenadas no disco rígido do microcomputador.

\section{Banco de Dados}

O banco de dados conta com 208 fotografias de mulheres brancas, 104 de mulheres pardas e 105 de mulheres pretas; 174 fotografias de homens brancos, 105 de homens pardos, 121 de homens pretos (Tabela 2.1). Dessas 817 fotografias que formam o banco de dados, 375 possuem algum problema que inviabilizam sua utilização na confecção do protótipo (como barba, cabelo na testa, imagem fora de foco, ou ainda, voluntários cuja idade estava fora da faixa etária pretendida), mas podem ser utilizadas em outros projetos em percepção de faces. 
Tabela 2.1: Quantidade de imagens capturadas de acordo com sexo e auto-declaração de cor/raça do participante.

\begin{tabular}{c|ccc|ccc|c}
\hline & $\begin{array}{c}\text { Homens } \\
\text { brancos }\end{array}$ & $\begin{array}{c}\text { Homens } \\
\text { pretos }\end{array}$ & $\begin{array}{c}\text { Homens } \\
\text { pardos }\end{array}$ & $\begin{array}{c}\text { Mulheres } \\
\text { brancas }\end{array}$ & $\begin{array}{c}\text { Mulheres } \\
\text { pretas }\end{array}$ & $\begin{array}{c}\text { Mulheres } \\
\text { pardas }\end{array}$ & Total \\
\hline $\begin{array}{c}\text { Imagens com } \\
\text { problemas }\end{array}$ & 41 & 09 & 28 & 57 & 08 & 09 & 152 \\
$\begin{array}{c}\text { Participantes } \\
\text { com mais de } 30 \\
\text { anos }\end{array}$ & 51 & 39 & 13 & 58 & 33 & 29 & 223 \\
$\begin{array}{c}\text { Imagens que } \\
\text { podem ser utili- } \\
\text { zadas na con- } \\
\text { fecção de protó- } \\
\text { tipos }\end{array}$ & 82 & 73 & 64 & 93 & 64 & 66 & 442 \\
\hline Total & 174 & 121 & 105 & 208 & 105 & 104 & 817 \\
\hline
\end{tabular}

* Fotografias que se encontram fora de foco ou em que o participante possui algum elemento facial interno que inviabiliza a utilização da imagem para a confecção de protótipos.

\section{Padronização das imagens}

Todas as 442 fotografias do banco de dados que preenchiam os requisitos preestabelecidos de idade e qualidade de imagem foram padronizadas. A padronização do enquadramento, alinhamento, tamanho (1240 x 1713 pixels na resolução de 150 dpı) e a distância inter-pupilar de $6 \mathrm{~cm}$ foi feita individualmente utilizando-se o Adobe PhotoShop. Com a utilização de uma máscara, alinhou-se a linha dos olhos na horizontal, a imagem foi redimensionada para se obter a distância de $6 \mathrm{~cm}$ entre as pupilas, padronizou-se o tamanho, resolução e enquadramento da imagem (com região dos olhos no centro da figura) o que pode ser observado na Figura 3.1. 


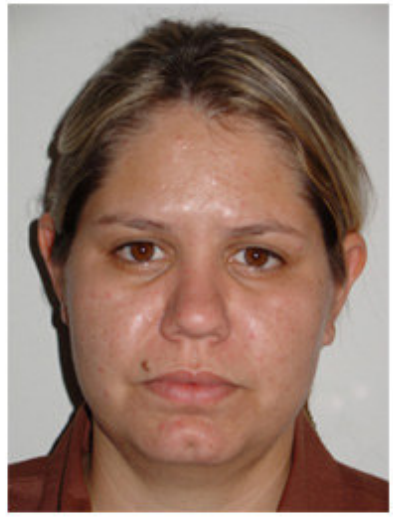

Fotografia original

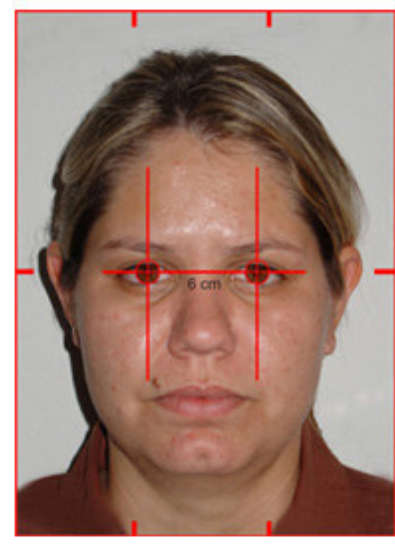

Fotografia com máscara para padronização

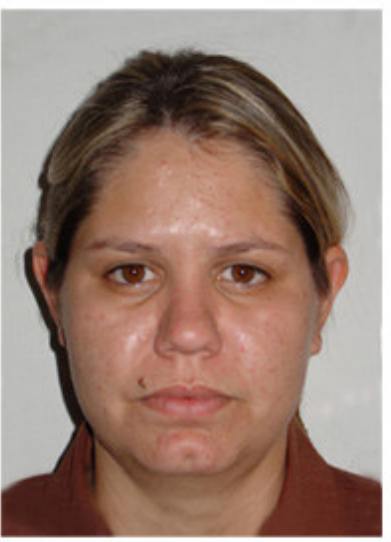

Resultado final

Figura 3.1: Todas as fotografias foram submetidas ao processo de padronização. A máscara foi utilizada para se colocar todas as fotografias no mesmo formato, resolução, posição dos olhos e distância entre as pupilas.

Completada a padronização, sortearam-se as 64 fotografias de cada grupo utilizadas para gerar o protótipo. Seis protótipos: femininos branco, preto e pardo; e masculinos branco, preto e pardo foram gerados da mesma forma, pela técnica de morphing.

\section{A Técnica de Morphing}

A técnica de computação gráfica utilizada para a confecção do protótipo, das caricaturas e anti-caricaturas foi a de morphing. Uma de suas aplicações é como ferramenta de animação e efeitos especiais cinematográficos. O termo morphing é utilizado para descrever a técnica de processamento de imagem quando há uma metamorfose, ou seja, uma imagem é transformada em outra. O algoritmo do morphing pode gerar qualquer imagem num contínuo de uma imagem "A" para uma "B" e a posição da imagem neste contínuo é especificada parametricamente. Essa parametrização é que nos dá a proporção de "A" e "B" na imagem 
gerada e conseqüentemente a similaridade em relação a "A" e "B" pode ser controlada (Steyvers, 1999).

Para se fazer um morfismo entre faces é necessário que se marque manualmente todos os pontos que definem os contornos da face e de cada elemento facial. Para cada ponto na primeira face há seu equivalente na segunda. Ao se utilizar esses pontos como referências "de partida" e "alvo", o algoritmo de morphing gerará as figuras intermediárias entre uma face e outra.

\section{A Confecção dos Protótipos}

Na confecção dos protótipos, para cada par de fotografias, considerou-se uma imagem "A" sendo a "de partida" e a outra "B" sendo a "alvo". Para os 32 pares de fotografias, os pontos que definem os contornos das faces foram marcados sendo que cada ponto marcado na face "de partida" havia seu correspondente na "alvo". Em todas as imagens utilizouse o mesmo número de pontos, totalizando 179 pontos em cada imagem. Duas a duas, foram feitas a sobreposição e interpolação média entre os pontos correspondentes das fotografias, como descrito na metodologia de Brennan (1985), Benson e Perrett (1991a, 1991b) e Rowland e Perret (1995). O produto da interpolação foi uma imagem cuja similaridade com as faces "de partida" e "alvo" é igual, ou seja, $50 \%$ de similaridade com cada uma das faces como pode-se observar na Figura 5.1. Esta imagem intermediária foi utilizada nos processos de sobreposição e interpolação seguintes. Dos 32 pares iniciais obtivemos 32 imagens intermediárias com igual similaridade entre faces partida e alvo. Seguindo as mesmas regras anteriores de marcação de pontos e de escolha da imagem intermediária, essas 32 imagens foram pareadas e submetidas ao processo de interpolação gerando 16 imagens intermediárias. Essas 16 imagens intermediárias também foram emparelhadas e interpoladas sob as mesmas regras anteriores. E assim fizeram-se sucessivas sobreposições e interpolações aos pares das imagens intermediárias até que se obtivesse uma única imagem, o protótipo. 


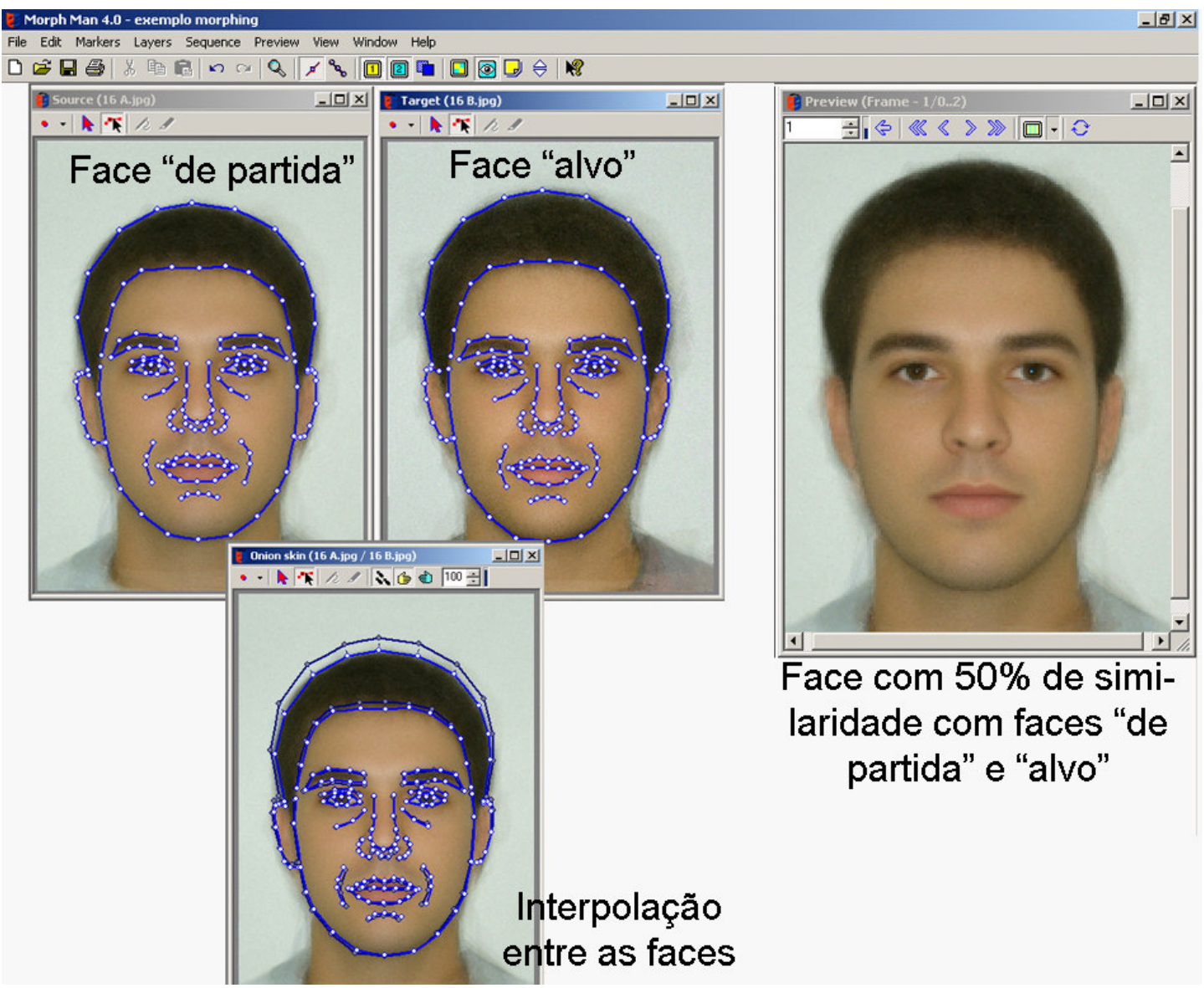

Figura 5.1: Manualmente, marcam-se vários os pontos que definem os contornos das características de cada uma das faces. Para cada ponto na Imagem "A", há um correspondente na imagem "B". As imagens são pareadas e interpoladas, duas a duas, gerando faces intermediárias cuja similaridade com as faces iniciais é de $50 \%$.

\section{Referências Bibliográficas}

Benson, P. J., \& Perrett, D. I. (1991a). Synthesising continuous-tone caricature. Image and Vision Computing, $\underline{9}, 123-129$.

Benson, P. J., \& Perrett, D. I. (1991b). Perception and recognition of phographic quality facial caricatures: implications for the recognition of natural images. European Journal of Cognitive Psychology, $\underline{3}, 105-135$.

Brennan, S. E. (1985). Caricature generator: the dynamic exaggeration of faces by computer. Leonardo, $\underline{18}, 170-178$. 
Rowland, D. A., \& Perret, D. I. (1995). Manipulating facial appearance through shape and color. IEEE Computer Graphics and Applications, 15, 70-76.

Steyvers, M. (1999). Morphing techniques for manipulating faces images. Behavior Research Methods, Instruments \&Computers, 31, 359-369. 


\section{APÊNDICE B - CONFECÇÃO DAS CARICATURAS E ANTI-CARICATURAS}

Assim que o protótipo foi gerado, pôde-se gerar as caricaturas e anti-caricaturas. As caricaturas foram feitas acentuando-se as diferenças entre uma face alvo e os protótipos e as anti-caricaturas foram confeccionadas atenuando essas diferenças. Na confecção da caricatura, o algoritmo do programa de morphing extrapola as diferenças que a face alvo possui em relação ao protótipo. $\mathrm{Na}$ anti-caricatura o algoritmo aproxima a forma da face alvo com a da face prototípica, sendo assim, as diferenças entre as formas das faces são cada vez menores.

Utilizando-se o programa Morph Man® v4 (http://www.stoik.com), foram confeccionados caricaturas e anti-caricaturas da face de 4 apresentadores (2 mulheres e 2 homens) do telejornal local para os Experimentos I e II.

\section{Distorções Holísticas: Estímulos para o Experimento I}

Primeiramente as imagens das faces foram padronizadas para que ficassem do mesmo tamanho e os olhos na mesma posição que os dos protótipos. Os pontos que definem os contornos de cada uma das quatro faces e de seus elementos faciais foram marcados manualmente. Para cada ponto marcado na face alvo havia seu equivalente no protótipo, num total de 179 pontos para cada imagem. Logo em seguida, esses pontos foram ajustados no protótipo facial. O algoritmo do programa computacional calculou a diferença entre cada ponto da face alvo e seu equivalente no protótipo e a representou por vetores. Essas diferenças foram utilizadas para se produzir as caricaturas e as anti-caricaturas. Somandose as proporções da diferença à face alvo, tivemos a caricatura, e, subtraindo-se a anticaricatura Figura 1.1. O grau de exagero é dado em porcentagem da diferença que foi adicionada ou subtraída da face alvo. Utiliza-se a denotação de + (positivo) para indicar que a diferença foi adicionada obtendo-se, portanto, uma caricatura, e - (negativo) quando a diferença foi subtraída, resultando na anti-caricatura. A face alvo poderia ser qualquer uma das quatro fotografias de pessoas conhecidas. Para cada face, foram feitas três séries de carica- 
turas e anti-caricaturas, baseando-se nos três protótipos (de mesmo gênero da face) previamente gerados como demonstrado naFigura 1.2.Foram feitas caricaturas e anti-caricaturas, com diferentes graus de exagero ( $\mathrm{de}+100 \%$ a $-100 \%$, com intervalos de $5 \%$ ).

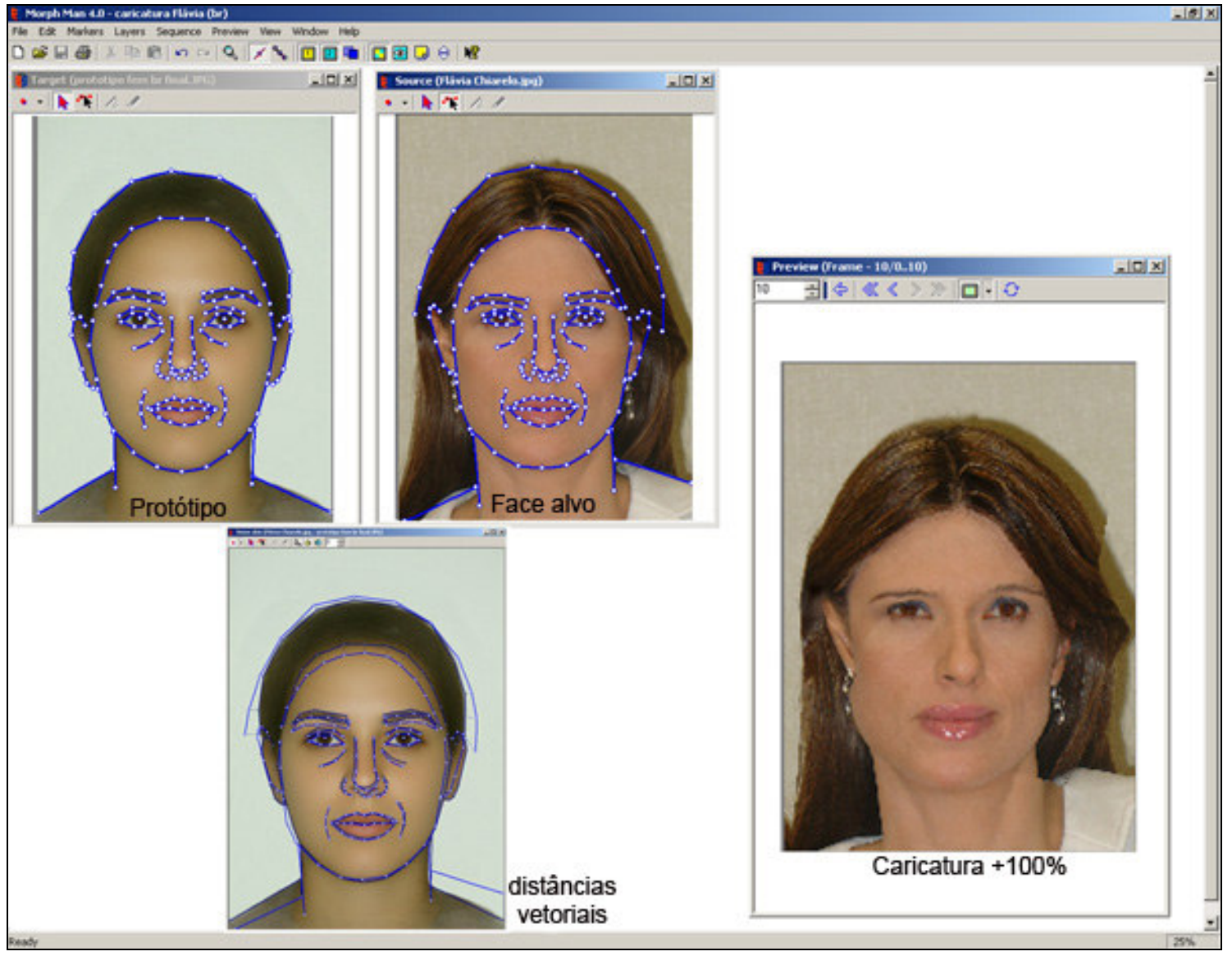

Figura 1.1: Todos os pontos que definem o contorno do protótipo e da face alvo são marcados manualmente. Para cada ponto na face alvo existe um correspondente no protótipo. Os pontos equivalentes das faces alvo e protótipo são sobrepostos e a distâncias vetoriais entre eles são determinados. Uma proporção da distância vetorial entre os pontos das faces é adicionada aos pontos da face alvo, delimitando-se assim o contorno da caricatura. No exemplo uma caricatura com $+100 \%$ de exagero. 


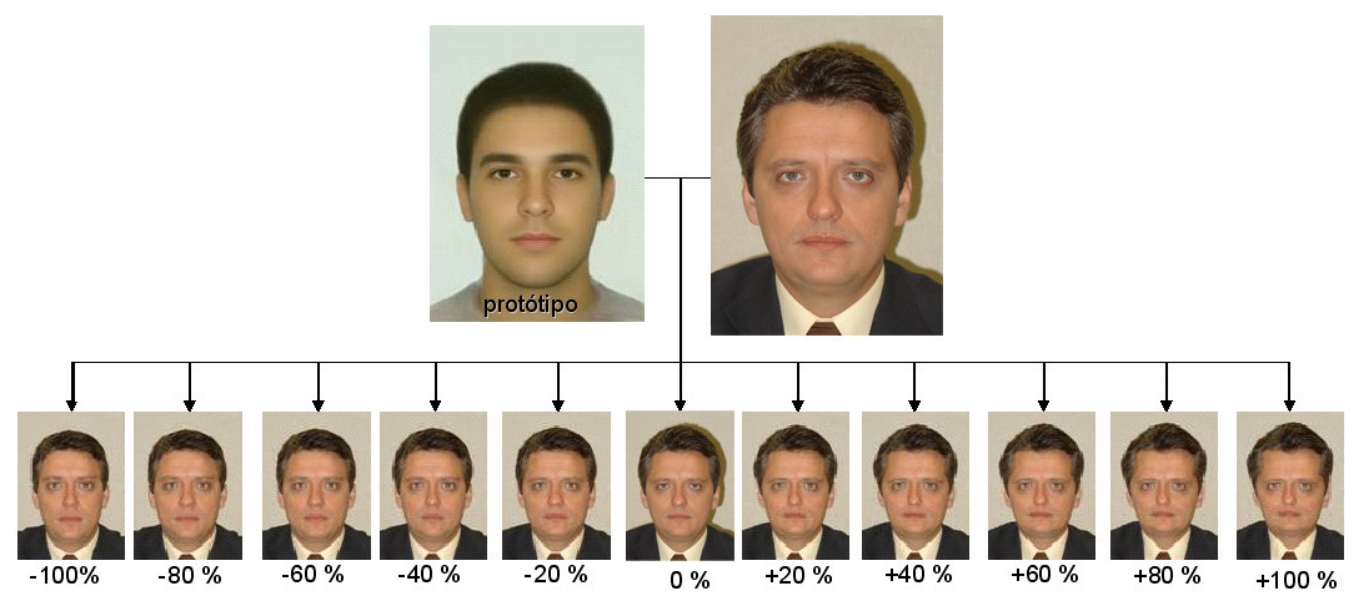

Exemplo de anti-caricaturas e caricaturas geradas a partir do protótipo masculino branco.

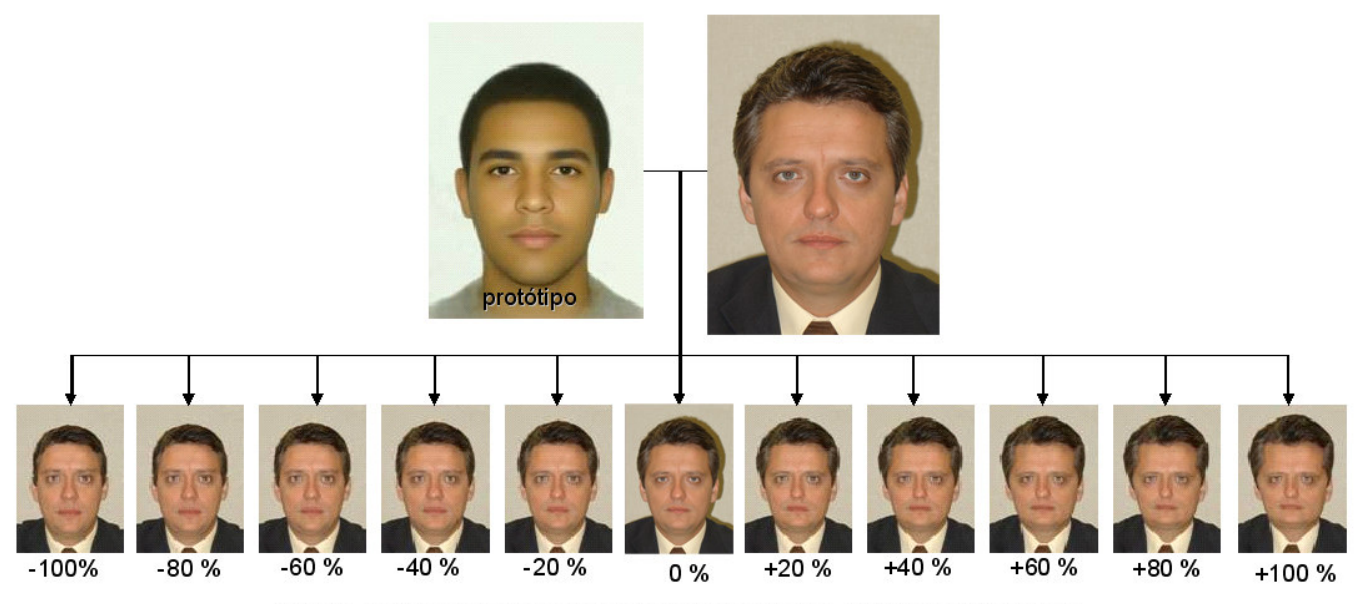

Exemplo de anti-caricaturas e caricaturas geradas a partir do protótipo masculino pardo.

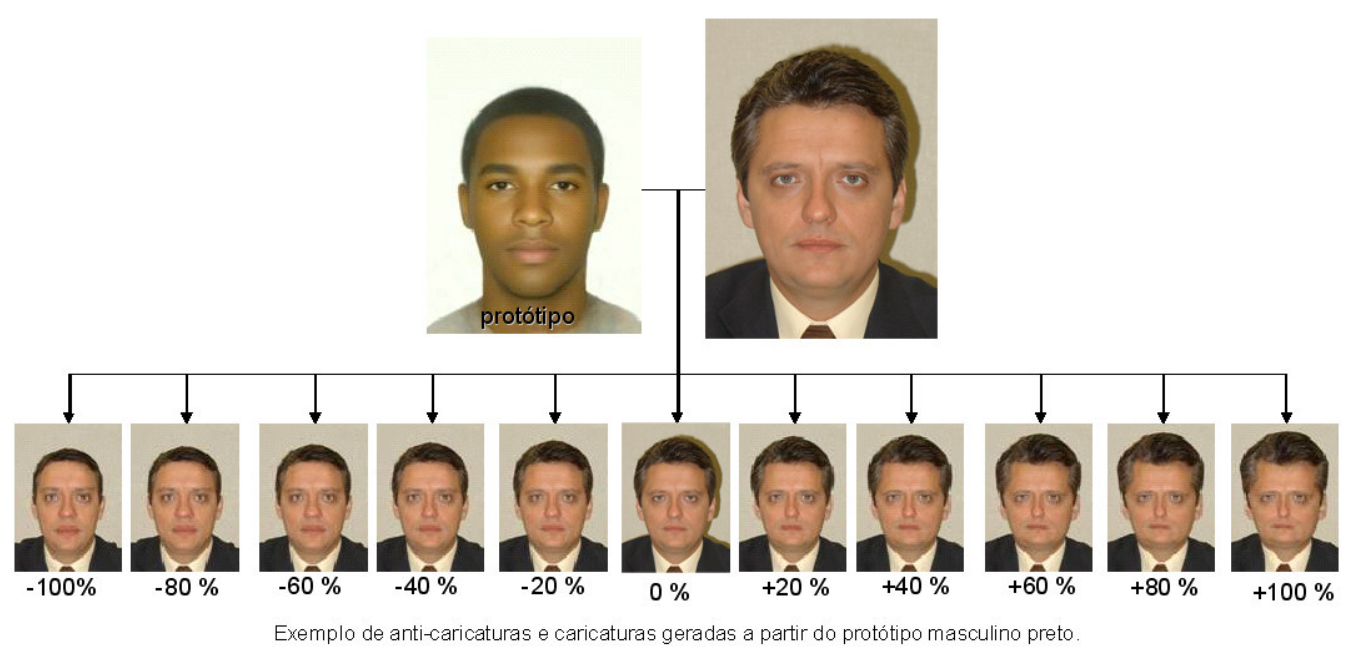

Figura 1.2: Exemplo de anti-caricaturas e caricaturas holísticas geradas a partir de cada um dos três protótipos masculinos de amostra brasileira. 


\section{Técnica de Camadas: Estímulos para o Experimento II}

O algoritmo do programa de morphing utilizado na pesquisa, além da caricatura total da face, permite que se exagere um determinado elemento facial sem que os demais aspectos da face sofram modificações (técnica de camadas ou layers). Para isto, marcaram-se os pontos que definem os elementos faciais internos a serem modificados e trabalhou-se com eles em uma camada (layer) separada (Figura 2.1). Foram geradas imagens em que apenas os olhos ou nariz ou boca sofreram modificações. Também se trabalhou com o exagero de combinações de elementos faciais: olhos-nariz, olhos-boca, nariz-boca e olhos-nariz-boca. Como nas anti-caricaturas e caricaturas anteriores, os exageros (variando entre $-100 \%$ e $+100 \%$, com intervalos de 10\%) foram obtidos a partir da comparação entre o elemento facial caricaturado nas faces alvo (as quatro faces de pessoas conhecidas) com o da face prototípica de raça branca (veja exemplo de caricatura e anti-caricatura em que apenas o elemento "boca" foi exagerado na Figura 2.2). 


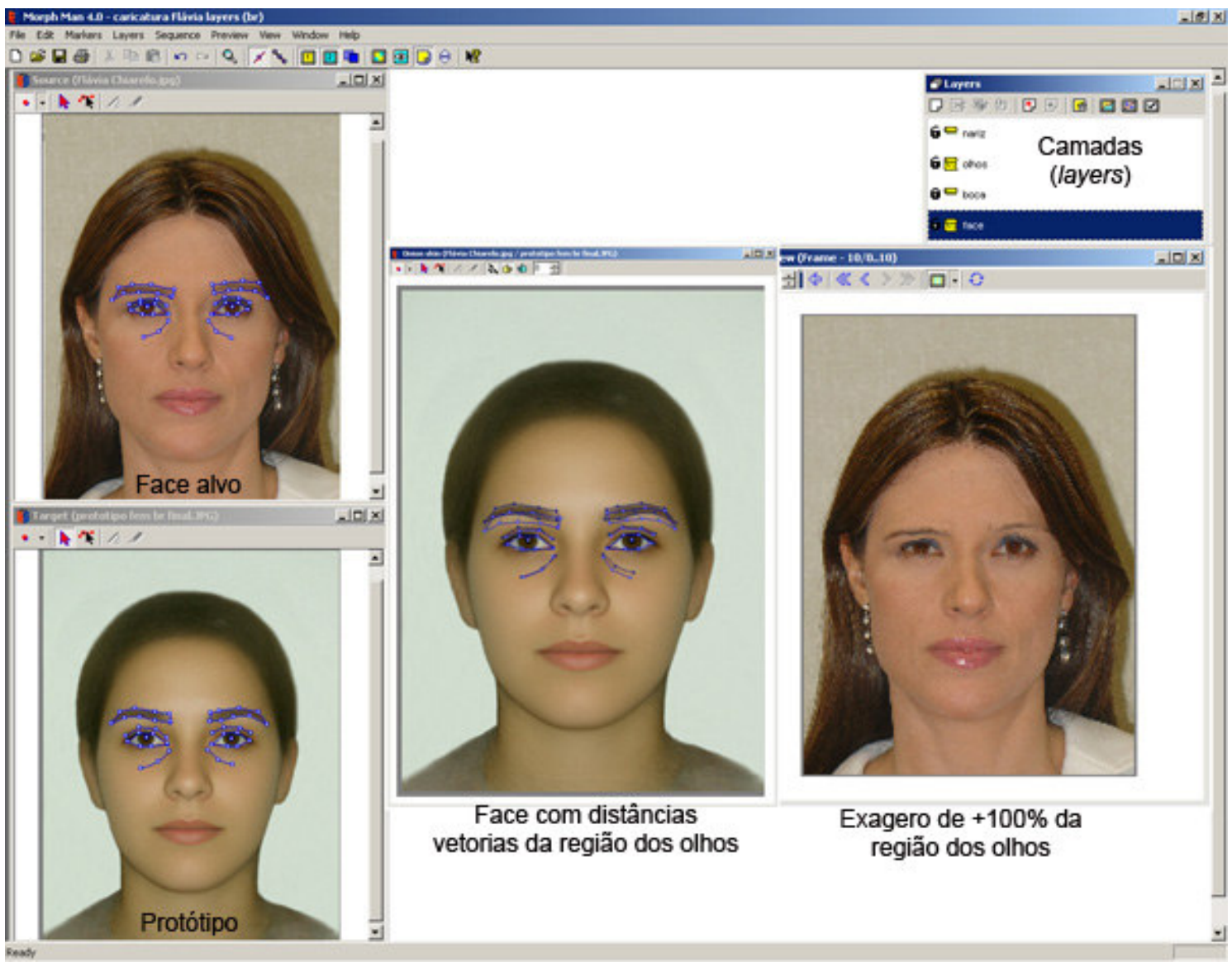

Figura 2.1: A face toda, sem nenhuma marcação, é selecionada para que não sofra modificações. Os pontos que definem o contorno do elemento facial do protótipo e da face alvo são marcados manualmente e são selecionados para serem trabalhados em uma camada diferente. Os pontos que definem do elemento facial na face alvo e no protótipo são correspondentes. Estes pontos são sobrepostos e a distâncias vetoriais entre eles são determinados. Uma proporção da distância vetorial entre os pontos é adicionada aos pontos da face alvo delimitando-se, assim, o contorno do elemento facial caricaturado, no exemplo acima temos a região dos olhos com um grau de exagero de $100 \%$. 


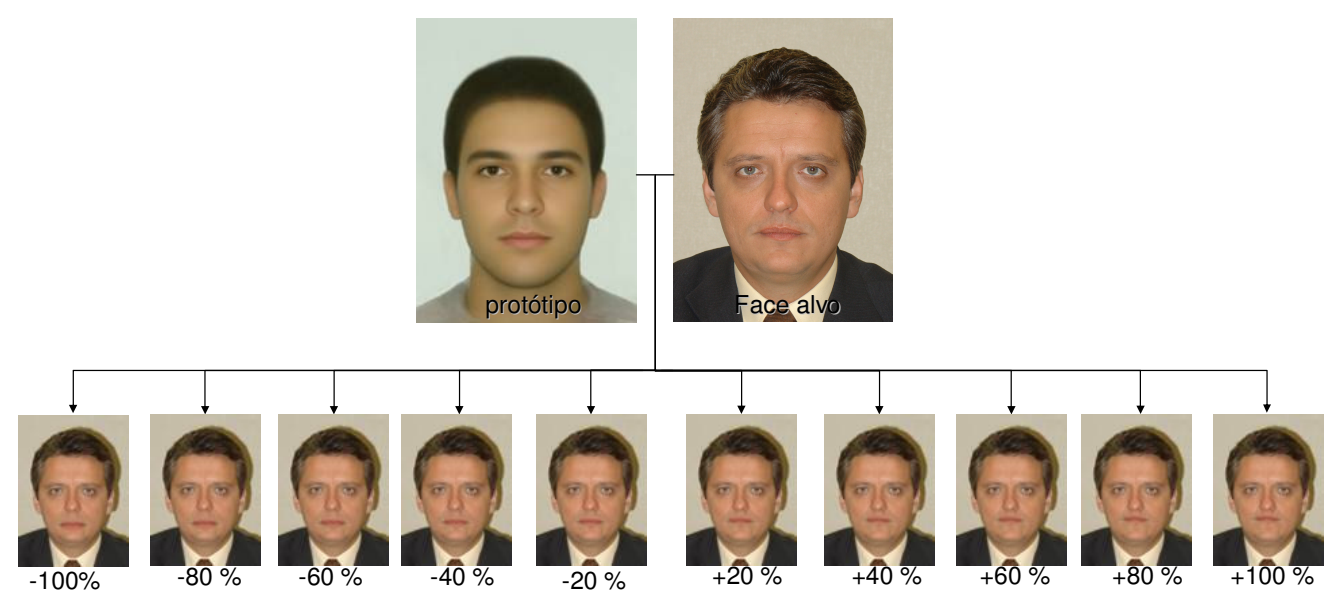

Figura 2.2: Exemplo de imagens em que apenas um elemento facial, no caso a boca, foi distorcido. 


\section{APÊNDICE C - TERMO DE AUTORIZAÇÃO DE USO DA IMAGEM}

Preencha os dados abaixo:

Idade que tinha na ocasião da fotografia:

Em relação a sua cor, você se classifica como:
( ) branca
( ) preta
( ) amarela
( ) parda
( ) indígena
( ) outra

\section{AUTORIZAÇÃO DO USO DE IMAGEM}

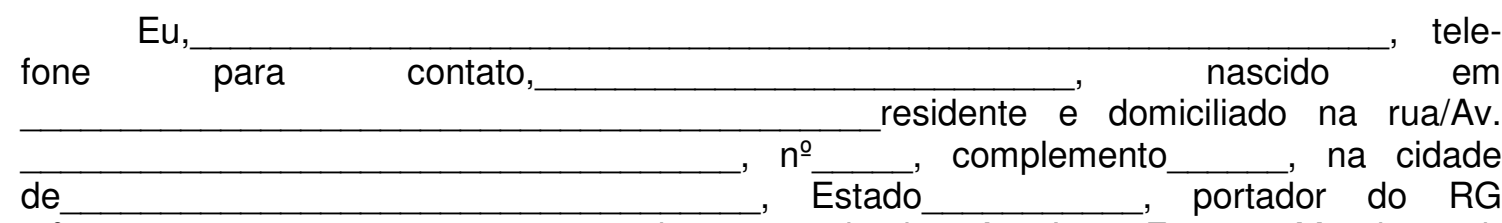

n. - _ autorizo a pesquisadora Ana Irene Fonseca Mendes, sob orientação do Prof. Dr. Sérgio Sheiji Fukusima, a utilizar minha imagem facial para fins de pesquisa em percepção e reconhecimento de faces.

Declaro estar ciente que a imagem poderá ser manipulada e modificada por meios gráficos e computacionais e também poderá ser divulgada em impressos acadêmicos (tais como artigos em revistas especializadas, capítulos de livros, resumos de anais e painéis de reuniões científicas) e em apresentações orais (tais como aulas, palestras, simpósios e comunicações orais em reuniões científicas).

Em casos de divulgações, nenhuma outra informação adicional sobre a identidade da pessoa, além da imagem facial, será fornecida.

Esta autorização é de caráter voluntário e não implica ônus financeiro por parte do doador da imagem. A divulgação da imagem não visa fins lucrativos. E os pesquisadores estão isentos de qualquer retribuição financeira pelo uso das imagens na pesquisa e nos meios de divulgação mencionados.

Ribeirão Preto, de de

Assinatura do doador

Assinatura do pesquisador

Pesquisador: Ana Irene Fonseca Mendes

RG: 26879581-2

CPF: 253384598-17

Endereço: Av dos Bandeirantes, 3900 - Ribeirão Preto/ SP 


\section{APÊNDICE D — TERMO DE CONSENTIMENTO LIVRE E ESCLARECIDO}

Esta pesquisa tem por objetivo investigar o reconhecimento facial em humanos. Os requisitos para você participar desta pesquisa são: ter visão normal com ou sem lentes corretivas e que sua participação seja voluntária.

A primeira tarefa a ser realizada será indicar se reconhece ou não a face apresentada. Logo em seguida será fazer um julgamento de quanto a face apresentada na tela do computador é parecida com a pessoa que você conhece.

O experimento não apresenta riscos à integridade da sua saúde física e mental e terá duração de aproximadamente 30 minutos.

É importante que você finalize a sessão experimental. Porém, se desejar interrompêla ou encerrá-la, assim poderá proceder em qualquer momento, sem prejuízo à sua pessoa.

Os dados gerados por esta pesquisa serão divulgados em reuniões e publicações científicas e as identidades dos participantes serão mantidas em sigilo.

Declaro que estou ciente das informações acima e concordo participar da pesquisa.

\section{Local e data:}

Nome do participante:

RG.:

Endereço:

Nome da pesquisadora: Ana Irene Fonseca Mendes

Nome do orientador: Sérgio Sheiji Fukusima

Endereço: Av. dos Bandeirantes, 3900.

Departamento de Psicologia e Educação - FFCLRP- USP

Fone: $602-4448$

\section{Assinatura do pesquisador:}

Assinatura participante: 


\section{ANEXO A — DOCUMENTO DE APROVAÇÃO DO COMITÊ DE ÉTICA EM \\ PESQUISA}

UNIVERSIDADE DE SÃO PAULO

FACULDADE DE FILOSOFIA, CIENCIAS E LETRAS DE RIBEIRĀO PRETO

COMITÊ DE ETICAEM PESQUISA-CEP

Of.CEtP/053/08.06.2004

Senhor(a) Pesquisador(a):

Comunicamos a V. Sa. que o trabalho intitulado

"Caricatura e Reconhecimento de Faces" foi analisado pelo Comitê de Ética em Pesquisa da FFCLRP-USP, e enquadrado na categoria: APROVADO, de acordo com o Processo CEP-FFCLRP n 137/2004 2004.1.532.59.8

Aproveitamos a oportunidade para apresentar nossos protestos de estima e consideração.

Atenciosamente,

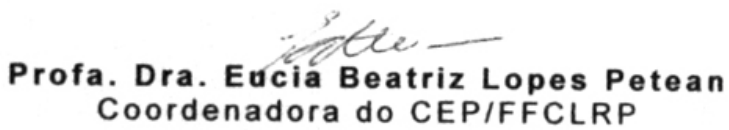

Ilustríssimo(a) Senhor(a)

ANA IRENE FONSECA MENDES

Departamento de Psicologia e Educação - FFCLRP-USP

C.C. Sergio S. Fukusima

CEP-FFCLRP-USP - Fone: (016) 602-3653 - Fax: (016) 633-5015

Avenida Bandeirantes, 3900 - Bloco A - 14040-901 - Ribeirăo Preto - SP - Brasil 